\title{
Field Observations, Preliminary Model Analysis, and Aquifer Thermal Efficiency
}

U.S. GEOLOGICAL SURVEY PROFESSIONAL PAPER 1530-A

Prepared in cooperation with the University of Minnesota and the Minnesota Geological Survey

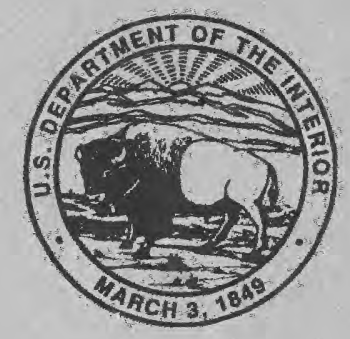




\section{AVAILABILITY OF BOOKS AND MAPS OF THE U.S. GEOLOGICAL SURVEY}

Instructions on ordering publications of the U.S. Geological Survey, along with prices of the last offerings, are given in the current-year issues of the monthly catalog "New Publications of the U.S. Geological Survey." Prices of available U.S. Geological Survey publications released prior to the current year are listed in the most recent annual "Price and Availability List." Publications that may be listed in various U.S. Geological Survey catalogs (see back inside cover) but not listed in the most recent annual "Price and Availability List" may be no longer available.

Reports released through the NTIS may be obtained by writing to the National Technical Information Service, U.S. Department of Commerce, Springfield, VA 22161; please include NTIS report number with inquiry.

Order U.S. Geological Survey publications by mail or over the counter from the offices given below.

\section{BY MAIL}

\section{Books}

Professional Papers, Bulletins, Water-Supply Papers, Techniques of Water-Resources Investigations, Circulars, publications of general interest (such as leaflets, pamphlets, booklets), single copies of Earthquakes \& Volcanoes, Preliminary Determination of Epicenters, and some miscellaneous reports, including some of the foregoing series that have gone out of print at the Superintendent of Documents, are obtainable by mail from

\section{U.S. Geological Survey, Map Distribution Box 25286, MS 306, Federal Center Denver, CO 80225}

Subscriptions to periodicals (Earthquakes \& Volcanoes and Preliminary Determination of Epicenters) can be obtained ONLY from the

\section{Superintendent of Documents Government Printing Office Washington, D.C. 20402} Documents.)

(Check or money order must be payable to Superintendent of Maps

For maps, address mail orders to

\section{U.S. Geological Survey, Map Distribution Box 25286, Bldg. 810, Federal Center Denver, CO 80225}

Residents of Alaska may order maps from

\author{
U.S. Geological Survey, Earth Science Information Center \\ 101 Twelfth Ave. - Box 12 \\ Fairbanks, AK 99701
}

\section{OVER THE COUNTER}

\section{Books and Maps}

Books and maps of the U.S. Geological Survey are available over the counter at the following U.S. Geological Survey offices, all of which are authorized agents of the Superintendent of Documents:

- ANCHORAGE, Alaska-Rm. 101, 4230 University Dr.

- LAKEWOOD, Colorado-Federal Center, Bldg. 810

- MENLO PARK, California-Bldg. 3, Rm. 3128, 345 Middlefield Rd.

- RESTON, Virginia-USGS National Center, Rm. 1C402, 12201 Sunrise Valley Dr.

- SALT LAKE CITY, Utah-Federal Bldg., Rm. 8105, 125 South State St.

- SPOKANE, Washington-U.S. Post Office Bldg., Rm. 135, West 904 Riverside Ave.

- WASHINGTON, D.C.-Main Interior Bldg., Rm. 2650, 18th and C Sts., NW.

\section{Maps Only}

Maps may be purchased over the counter at the following U.S. Geological Survey offices:

- FAIRBANKS, Alaska-New Federal Bldg., 101 Twelfth Ave.

- ROLLA, Missouri-1400 Independence Rd.

- STENNIS SPACE CENTER, Mississippi-Bldg. 3101 


\section{Field Observations, Preliminary Model Analysis, and Aquifer Thermal Efficiency}

By R.T. MILLER and G.N. DELIN

CYCLIC INJEGTION, STORAGE, AND WITHDRAWAL OF HEATED WATER IN A SANDSTONE AQUIFER AT ST. PAUL, MINNESOTA

U.S. GEOLOGICAL SURVEY PROFESSIONAL PAPER 1530-A

Prepared in cooperation with the University of Minnesota and the Minnesota Geological Survey

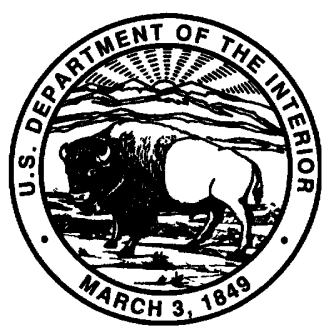




\title{
U.S. DEPARTMENT OF THE INTERIOR \\ BRUCE BABBITT, Secretary
}

\section{U.S. GEOLOGICAL SURVEY}

\author{
Dallas L. Peck, Director
}

\begin{abstract}
Any use of trade, product, or firm names in this publication is for descriptive purposes only and does not imply endorsement by the

U.S. Government
\end{abstract}

\section{Library of Congress Cataloging in Publication Data}

Miller, Robert T.

Cyclic injection, storage, and withdrawal of heated water in a sandstone aquifer at St. Paul, Minnesota / by R.T. Miller.

p. $\quad$ cm. - (Field observations, preliminary model analysis, and aquifer thermal efficiency) (U.S. Geological Survey professional paper; $1530-\mathrm{A})$

"Prepared in cooperation with the University of Minnesota and the Minnesota Geological Survey."

Includes bibliographical references ( $\mathrm{p}$.

Supt. of Docs. no.: I 19.16:1530-A

1. Hot-air heating. 2. Hot water. 3. Water-storage-Minnesota-St. Paul. 4. Aquifers-Minnesota-St. Paul. I. University of Minnesota. II. Minnesota Geological Survey. III. Title. IV. Series. V. Series: U.S. Geological Survey professional paper ; $1530-\mathrm{A}$.

TH7602.M55 1993

$697^{\prime} .4-\mathrm{dc} 20$

$92-23497$

For sale by U.S. Geological Survey, Map Distribution

Box 25286, MS 306, Federal Center, Denver, CO 80225 


\section{CONTENTS}

\begin{tabular}{|c|c|c|}
\hline Page & & Page \\
\hline stract. & Preliminary Modeling Analysis-Continued & \\
\hline roduction... & Model Equations...... & $\mathrm{A} 27$ \\
\hline Purpose and Scope & Description of Radial-Flow Model......... & 28 \\
\hline 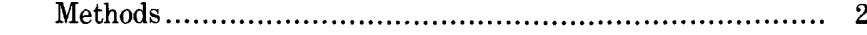 & 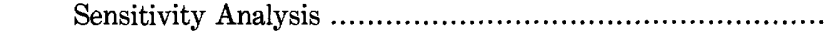 & 29 \\
\hline 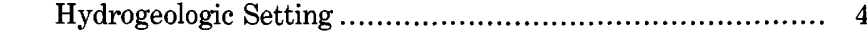 & Approach . & 29 \\
\hline 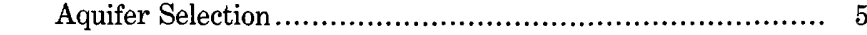 & Hydraulic and Thermal Properties.... & 31 \\
\hline Location of Production and Observation Wells .................. 5 & Ratio of Horizontal to Vertical Hydraulic & \\
\hline Instrumentation of Observation Wells ........................... 7 & Conductivity ........................ & 31 \\
\hline 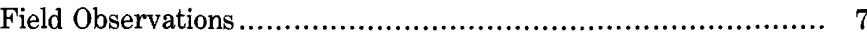 & Rock-Thermal Conductivity ............ & 32 \\
\hline 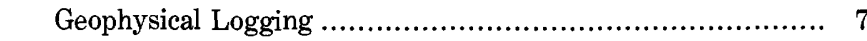 & Horizontal Hydraulic Conductivity................ & 32 \\
\hline 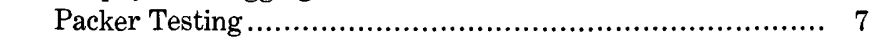 & Porosity ......................................... & 33 \\
\hline Production Well Completion and Well-Efficiency Testing....... 9 & Rock-Heat Capacity ......................... & 34 \\
\hline Hydraulic Properties .................................................. 16 & Thermal Dispersivity.......................... & 35 \\
\hline Estimates of Transmissivity From Step-Drawdown & 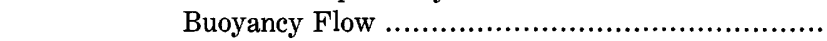 & 36 \\
\hline 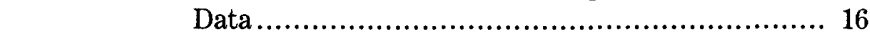 & 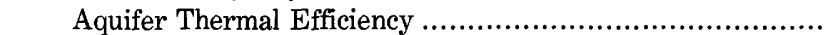 & 40 \\
\hline Estimates of Transmissivity and Areal Anisotropy & 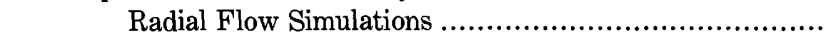 & 41 \\
\hline From Constant-Rate Aquifer Tests.................. 19 & Three-Dimensional Model.............................................. & 44 \\
\hline Estimates of Effective Porosity................................ 21 & Finite-Difference Grid Design ................................ & 44 \\
\hline Ambient-Temperature Water-Injection Testing ................ 21 & Flux Calculation at Model Boundaries .................... & 48 \\
\hline liminary Modeling Analysis.......................................... 25 & Model Calibration for Isothermal Conditions ............... & 51 \\
\hline 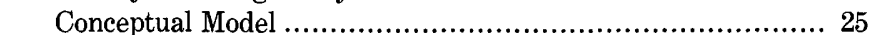 & 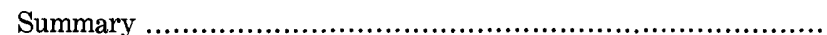 & 52 \\
\hline Description of Numerical Modeling ............................... 27 & References Cited .... & 54 \\
\hline
\end{tabular}

\section{ILLUSTRATIONS}

Page

2. Plan view of the Aquifer Thermal-Energy Storage site.

3. Depths of observation well screened intervals and measureme

4. Borehole geophysical logs of self potential, specific conductance, and natural gamma for corehole AC1 and natural gamma for corehole $\mathrm{BC} 1$ and observation well $\mathrm{CM} 1$.....

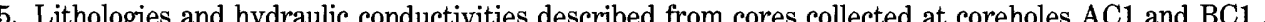

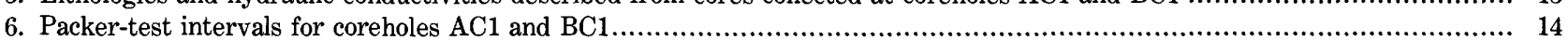

7. Hydraulic zonation from the St. Lawrence Formation through the Eau Claire Formation based on interpretation of

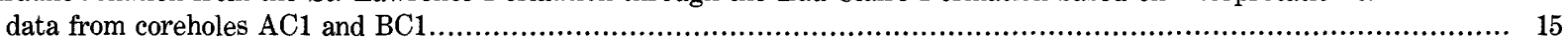

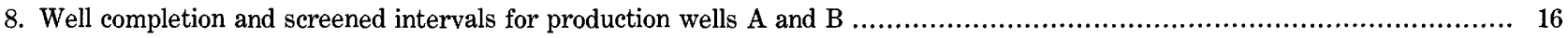

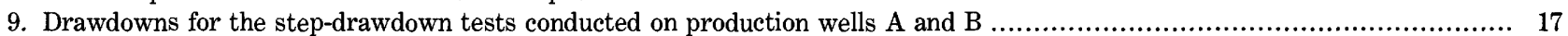

10. Relation of discharge to drawdown divided by discharge for step-drawdown test data from production wells $\mathrm{A}$ and $\mathrm{B}$........... 18

11. Recovery of ground-water levels following the step-drawdown test at production well B....................................... 18

12. Arbitrary coordinate system, in meters, indicating location and known deviation of production wells $A$ and $B$ and observation wells AC1, AM1, AM2, AM3, AS1, BC1, BS1, and CM1 ..............................................20

13. Natural gamma, neutron porosity, and gamma-gamma density logs with laboratory-determined values of effective porosity .... 22

14. Pressure changes for injection at 8.0 liters per second at observation well AM2 in the upper and lower parts of the Franconia Formation and in the Ironton and Galesville Sandstones and in production well A ...............................2. 23

15. Pressure changes in production well $\mathrm{A}$ at 18.9 liters per second after 1,440 minutes of injection at 8.0 liters per second......... 23

16. Pressure change, pumping rate, and dissolved oxygen content during rehabilitation of production well A .......................... 24 
17. Pressure changes for injection at 18.6 liters per second at observation well AM2 in the upper part of the

Franconia Formation and in the Ironton and Galesville Sandstones and in production well A

18. Water-level measurements from February 1981 through January 1982 for the St. Lawrence, Franconia, and

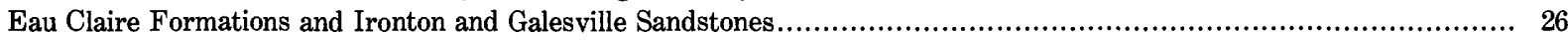

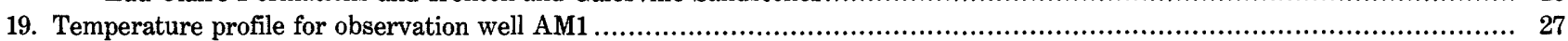

20. Flow net showing a doublet-well system similar to the Aquifer Thermal-Energy Storage system and the preliminary model boundary

21. Flow net within the preliminary model boundary for a doublet-well system similar to the Aquifer Thermal-Energy Storage system

22-26. Graphs showing:

22. Model-computed temperatures for different values of horizontal to vertical hydraulic conductivity...................... 31

23. Model-computed temperatures for different values of rock-thermal conductivity ........................................ 32

24. Model-computed temperatures for different values of horizontal hydraulic conductivity ................................ 33

25. Model-computed temperatures for different values of aquifer porosity ................................................. 34

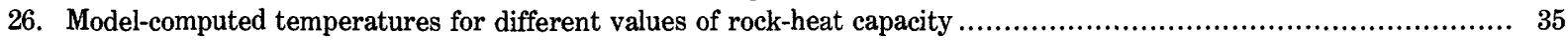

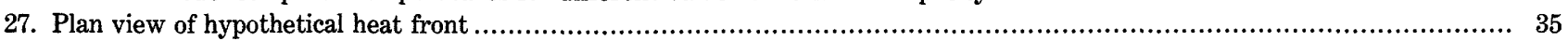

28. Graph showing model-computed temperatures for different values of thermal dispersivity ....................................... 36

29. Horizontal injection of warm water in an aquifer with excessive thermal stratification illustrating tilting of the thermal

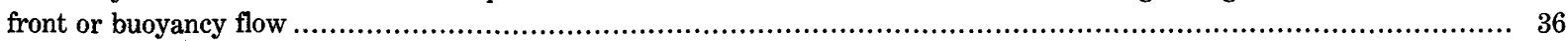

30-38. Graphs showing:

30. Model-computed temperature profiles at the end of simulated injection, storage, and withdrawal for assumed base conditions .....

31. Model-computed temperature profiles at the end of simulated injection, storage, and withdrawal for base conditions and horizontal equal to vertical hydraulic conductivity del-computed temperature profiles at the end of simulated injection, storage, and withdrawal for hydraulic conductivities equal to 10 times the base value

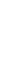


3. Specific capacity, transmissivity, relative horizontal hydraulic conductivity, and interval tested for inflatable packer tests on coreholes AC1 and BC1

4. Calculated drawdowns for various pumping rates for production wells $\mathrm{A}$ and $\mathrm{B}$.

5. Well efficiencies for production wells A and B

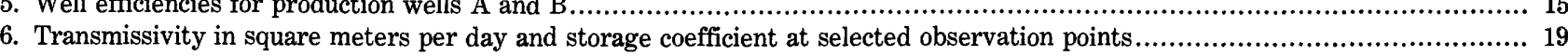

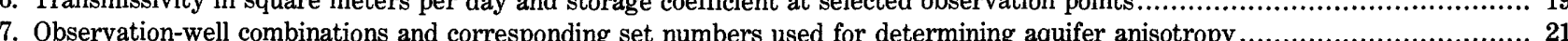

8. Computed values of transmissivity, in square meters per day, storage coefficient, and direction of major axis of

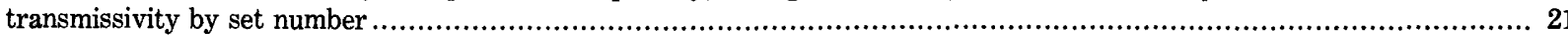

9. Hydraulic zonation, thickness, and horizontal hydraulic conductivity determined from borehole geophysical logs, core samples,

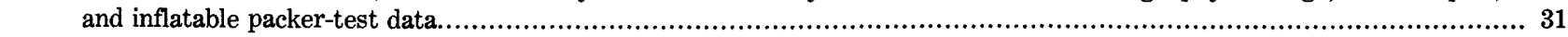

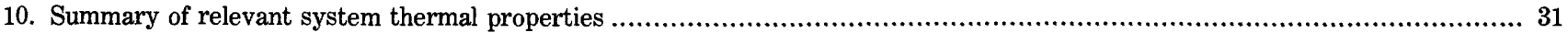

11. Layer number, thickness, and corresponding hydrogeologic unit of vertical grid spacing for the three-dimensional model.......... 49

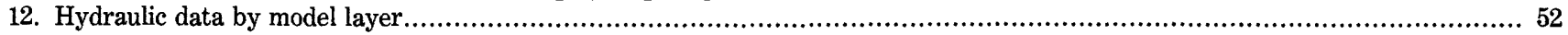

13. Difference in computed heads for injection and withdrawal rates of 15.8 and 22.1 liters per second as compared to 18.9 liters per second for a flux-boundary condition determined for 18.9 liters per second

\section{CONVERSION FACTORS AND VERTICAL DATUM}

\begin{tabular}{|c|c|c|}
\hline Multiply metric units & $\mathrm{By}$ & To obtain inch-pound units \\
\hline liter per second $(\mathrm{L} / \mathrm{s})$ & 15.85 & gallon per minute (gal/min) \\
\hline meter $(\mathrm{m})$ & 3.281 & foot $(\mathrm{ft})$ \\
\hline meter per day $(\mathrm{m} / \mathrm{d})$ & 3.281 & foot per day (ft/d) \\
\hline square meter per day $\left(\mathrm{m}^{2} / \mathrm{d}\right)$ & 10.76 & square foot per day $\left(\mathrm{ft}^{2} / \mathrm{d}\right)$ \\
\hline $\begin{array}{r}\text { joules per meter per day per degree } \\
\text { Celsius }\left[((\mathrm{J} / \mathrm{m}) / \mathrm{d}) /{ }^{\circ} \mathrm{C}\right]\end{array}$ & $1.605 \times 10^{-4}$ & $\begin{array}{l}\text { British thermal unit per foot per day per } \\
\text { degree Fahrenheit } \\
{\left[((\mathrm{Btu} / \mathrm{ft}) / \mathrm{d}) /{ }^{\circ} \mathrm{F}\right]}\end{array}$ \\
\hline $\begin{array}{r}\text { joules per cubic meter per degree } \\
\text { Celsius }\left[\left(\mathrm{J} / \mathrm{m}^{3}\right) /{ }^{\circ} \mathrm{C}\right]\end{array}$ & $1.492 \times 10^{-5}$ & $\begin{array}{l}\text { British thermal unit per cubic foot per } \\
\text { degree Fahrenheit }\left[\left(\mathrm{Btu} / \mathrm{ft}^{3}\right) /{ }^{\circ} \mathrm{F}\right]\end{array}$ \\
\hline kilopascal (kPa) & 0.1450 & pound-force per square inch $\left(\mathrm{lbf} / \mathrm{in}^{2}\right)$ \\
\hline \multicolumn{3}{|c|}{ Temperature } \\
\hline degree Celsius $\left({ }^{\circ} \mathrm{C}\right)$ & ${ }^{\circ} \mathrm{F}=1.8$ temp ${ }^{\circ} \mathrm{C}+32$ & degree Fahrenheit $\left({ }^{\circ} \mathrm{F}\right)$ \\
\hline
\end{tabular}

Sea level: In this report "sea level" refers to the National Geodetic Vertical Datum of 1929 (NGVD of 1929) - a geodetic datum derived from a general adjustment of the first-order level nets of both the United States and Canada, formerly called Sea Level Datum of 1929. 



\title{
CYCLIC INJECTION, STORAGE, AND WITHDRAWAL OF HEATED WATER IN A SANDSTONE AQUIFER AT ST. PAUL, MINNESOTA
}

\section{FIELD OBSERVATIONS, PRELIMINARY MODEL ANALYSIS, AND AQUIFER THERMAL EFFICIENCY}

\author{
By R.T. Miller and G.N. Delin
}

\section{ABSTRACT}

In May 1980, the University of Minnesota began a project to evaluate the feasibility of storing heated $\left(150\right.$ degrees Celsius $\left.\left({ }^{\circ} \mathrm{C}\right)\right)$ water in the deep (180 to 240 meters $(\mathrm{m})$ ) Franconia-Ironton-Galesville aquifer and later recovering it for space heating. The Aquifer Thermal-Energy Storage (ATES) system was a doublet-well design in which the injection and withdrawal wells were spaced approximately $250 \mathrm{~m}$ apart. High-temperature water from the university's steam-generation facilities supplied heat for injection. Water was pumped from one of the wells through a heat exchanger, where heat was added or removed. Water then was injected back into the aquifer through the other well. The experimental plan for testing the ATES system consisted of a series of short-term hot-water injection, storage, and withdrawal cycles. Each cycle was 24 days long, and each injection, storage, and withdrawal step of the cycle was 8 days.

The Franconia-Ironton-Galesville aquifer is a consolidated sandstone, approximately $60 \mathrm{~m}$ thick, the top of which is approximately $180 \mathrm{~m}$ below the land surface. It is confined above by the St. Lawrence Formation-a dolomitic sandstone $8 \mathrm{~m}$ thick-and below by the Eau Claire Formation-a shale $30 \mathrm{~m}$ thick. Initial hydraulic testing with inflatable packers indicated that the aquifer has four hydraulic zones with distinctly different values of relative horizontal hydraulic conductivity. The thickness of each zone was determined by correlating data from geophysical logs, core samples, and the inflatable-packer tests.

A comprehensive network for data collection, storage, and analysis was designed to monitor temperature and pressure changes during the ATES test cycles. A total of 22 pressure transducers and 56 thermocouples monitored pressures and temperatures in the aquifer and in the upper and lower confining units.

Temperature and pressure measurements were collected in observation well nests at distances of approximately 7 and $14 \mathrm{~m}$ from the production wells. All pressure and temperature data were transmitted through buried cables to a central data logger, where the measurements were viewed independently or stored on computer magnetic tape for later analysis. Interactive computer programs were available to display data stored on magnetic tapes as individual measurements or as plots of pressure and temperature versus time.

Analyses of step-drawdown and constant-discharge aquifer tests indicate that the Franconia-Ironton-Galesville aquifer is anisotropic in the horizontal plane. Major and minor transmissivities are 101.5 and $44.6 \mathrm{~m}^{2} / \mathrm{d}$ (square meters per day), respectively, for the Ironton and Galesville Sandstones and 40.0 and $24.0 \mathrm{~m}^{2} / \mathrm{d}$, respectively, for the upper part of the Franconia Formation. The average transmissivity of the entire Franconia-Ironton-Galesville aquifer is about $98 \mathrm{~m}^{2} / \mathrm{d}$. Effective porosity ranges from 0.25 to 0.31 , and the average storage coefficient is $4.5 \times 10^{-5}$.

Two computer models were constructed to simulate the movement of ground water and heat. The first was a nonisothermal, isotropic, single-phase, radial, ground-water flow and thermal-energy-transport model that was constructed to examine the sensitivity of model results to various hydraulic and thermal properties. The model also was used to study the potential for buoyancy flow within the aquifer and the effect of various cyclic injection and withdrawal schemes on the relative thermal efficiency of the aquifer. The second model was a threedimensional ground-water flow and thermal-energy-transport model that was constructed to incorporate the anisotropy of the aquifer.

In the first model, the sensitivity analysis assumed 8 days of injection of $150^{\circ} \mathrm{C}$ water at 18.9 liters per second $(\mathrm{L} / \mathrm{s}), 8$ days of storage, and 8 days of withdrawal of hot water at $18.9 \mathrm{~L} / \mathrm{s}$. The analysis indicates that, for practical ranges of hydraulic and thermal properties, the ratio of horizontal to vertical hydraulic conductivity is the least important property and thermal dispersivity is the most important property used to compute temperature and aquifer thermal efficiency.

Buoyancy flow was examined for several values of hydraulic conductivity and ratios of horizontal to vertical hydraulic conductivities. For the assumed base values of hydraulic and thermal properties, buoyancy flow was negligible. The greatest simulated buoyancy flow resulted from simulations in which horizontal hydraulic conductivity was increased to ten times the base value and in which the vertical hydraulic conductivity was set equal to the horizontal hydraulic conductivity.

The effects of various injection and withdrawal rates and durations on computed values of aquifer relative-thermal efficiency and final well-bore temperature were studied for five 1-year hypothetical test cycles of injection and withdrawal. The least efficient scheme was 8 months injection of $150^{\circ} \mathrm{C}$ water at $18.9 \mathrm{~L} / \mathrm{s}$ and 4 months of withdrawal of hot water at $18.9 \mathrm{~L} / \mathrm{s}$. The most efficient scheme was obtained with 6 months of injection of $150^{\circ} \mathrm{C}$ water at $18.9 \mathrm{~L} / \mathrm{s}$ and 6 months of withdrawal of hot water at $37.8 \mathrm{~L} / \mathrm{s}$. The hypothetical simulations indicate that the calibrated model of the doublet-well system would be a valuable tool for use by the university in selecting a highly efficient system operation.

In the second model, analytical solutions of anisotropic hydraulic flow around the doublet-well system were obtained to provide fluid-flux boundary conditions around the heat-injection well in three dimensions. 
This information simplified simulation of the doublet-well system because only the heat injection well needed to be simulated.

This second model was calibrated with data from an 8-day ambienttemperature injection test at $18.9 \mathrm{~L} / \mathrm{s}$. Boundary-flux conditions were examined for nonisothermal conditions by simulating 8 days of injection of $150^{\circ} \mathrm{C}$ water at $18.9 \mathrm{~L} / \mathrm{s}$.

Results of simulations using both models indicate that the fluxboundary conditions are adequate for simulations of short-term heatinjection testing.

\section{INTRODUCTION}

During the past decade, the concept of Aquifer Thermal-Energy Storage (ATES) has received increasing attention regarding its potential to decrease energy consumption and environmental pollution. Kazmann (1971), Meyer and Todd (1973), Hausz (1974), and Meyer and others (1976) were among the first to discuss the ATES concept. Most of these discussions, however, were restricted to economic and institutional concerns. Injection of heated or cooled fluids into aquifers had been practiced for many years (Leggette and Brashears, 1938; Guyton, 1946), but field experiments designed to evaluate the feasibility of the ATES concept for long-term, large-scale energy storage were not described until 1975 (Werner and Kley, 1977), and the first demonstration project in the United States did not begin until 1976 (Molz and others, 1978). There have been many other contributions to understanding and evaluating the ATES concept and they are described or summarized in Mercer and others (1980), Tsang (1979), and Lawrence Berkeley Laboratory (1978).

In May 1980, the University of Minnesota started a project to evaluate use of a deep, confined sedimentary bedrock aquifer located beneath the St. Paul Campus for thermal-energy storage. The project was funded by the U.S. Department of Energy through Battelle Pacific Northwest Laboratories. Other participants in the project included the Minnesota Geological Survey, the Minnesota Energy Agency, Orr-Schelen-Mayeron and Associates, National Biocentrics, Inc., and the U.S. Geological Survey (USGS). The project was designed to evaluate the feasibility and effects of storing hightemperature $\left(150^{\circ} \mathrm{C}\right)$ water in the Franconia-IrontonGalesville aquifer beneath the St. Paul Campus, and to later recover the heat for water and space heating.

The University of Minnesota test facility was a doublet-well system with a spacing of approximately $250 \mathrm{~m}$. Initial testing of the ATES system was with a series of hot-water injection, storage, and withdrawal cycles. Each cycle was 24 days long and the injection, storage, and withdrawal steps of the cycle were each 8 days long. During the injection and withdrawal steps, water was pumped from the Franconia-IrontonGalesville aquifer from one of the wells, transported through a heat exchanger where it was heated or cooled, and then injected back into the aquifer through the other well. The underlying geology at the ATES site is shown in figure 1.

The objectives of the USGS in evaluating the ATES concept were to (1) develop an understanding of the ground-water-flow system in the vicinity of the site, (2) identify the hydraulic properties of the ground-waterflow system that are most important with respect to thermal-energy storage and identify data-collection needs for monitoring and evaluation of aquifer-system performance, (3) develop a method to evaluate flow and thermal-energy transport for various cyclic injection and withdrawal schemes and aid selection of an efficient well-system design, and (4) aid in the collection of hydraulic and thermal data during injection and withdrawal tests and aid in the design of a data-processing system to facilitate entry of the data into computer storage.

\section{PURPOSE AND SCOPE}

This report describes the (1) analysis of field observations for aquifer characterization and observation network design, (2) preliminary model analysis to determine model sensitivity to hydraulic and thermal characteristics and to facilitate final model design, and (3) aquifer thermal efficiency.

This report is the first of three reports that describes the potential for thermal-energy storage within the Franconia-Ironton-Galesville aquifer located beneath the St. Paul campus of the University of Minnesota.

\section{METHODS}

To meet the objectives described in this report, data from previous studies were collected and the analytical solutions to ground-water flow and thermal-energy transport were used to design the production and observation well network. Geophysical logging, packer testing, aquifer tests, step-drawdown tests, and injection tests were conducted in the production well, and in some observation wells, to obtain information on aquifer hydraulic properties.

A nonisothermal, isotropic, single-phase, radial-flow, ground-water flow and thermal-energy transport model was constructed to (1) examine the sensitivity of various hydrologic and thermal properties of the aquifer and (2) investigate the relative efficiency of the ATES system for different injection and withdrawal rates and duration. A three-dimensional, anisotropic, single-phase, nonisothermal ground-water flow and thermal-energy trans- 


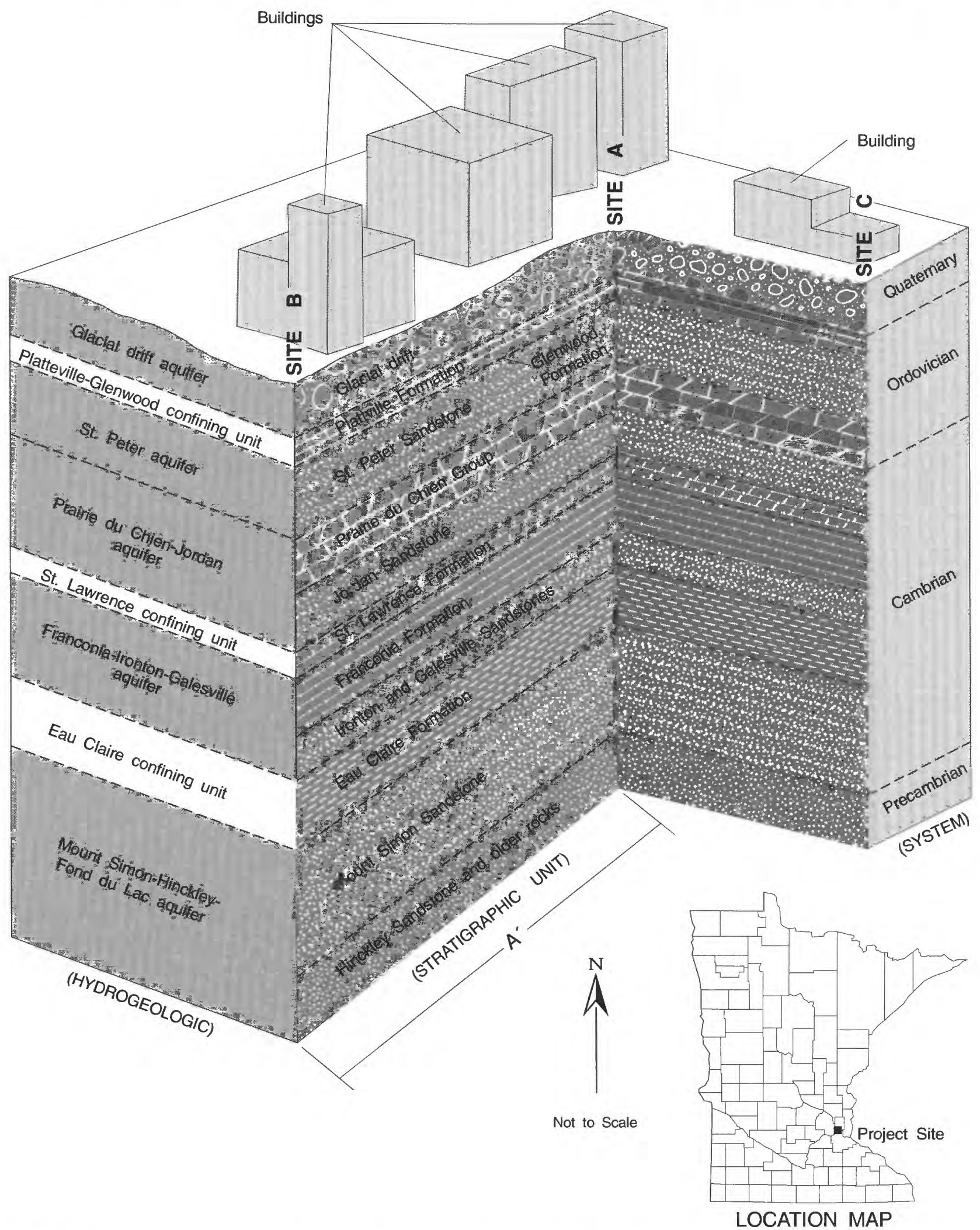

FIGURE 1. - Location and generalized schematic of hydrogeology of the Aquifer Thermal-Energy Storage (ATES) site. (Modified from Walton, 1981.) 
port model also was constructed for calibration with ambient temperature injection and withdrawal field-test data.

\section{HYDROGEOLOGIC SETTING}

The St. Paul metropolitan area is underlain by a stratified sequence of Proterozoic and early Paleozoic sedimentary formations consisting of porous sandstone and fractured dolomite which can be grouped into four major regional aquifers. The aquifers generally are separated by semipermeable sandstone, siltstone, and shale formations. The major aquifers are the St. Peter, Prairie du Chien-Jordan, Franconia-Ironton-Galesville, and Mount Simon-Hinckley-Fond du Lac (fig. 1).

The St. Peter aquifer is St. Peter Sandstone, which is composed of a light-yellow or white, massive, quartzose, fine- to medium-grained, well-sorted, and friable sandstone. Thin beds of siltstone and shale near the base of the St. Peter Sandstone form a lower confining layer. The upper confining layer, consisting of the Glenwood and Platteville Formations, overlies the St. Peter Sandstone and is in contact with glacial drift. The St. Peter aquifer is approximately $45 \mathrm{~m}$ below land surface and is $50 \mathrm{~m}$ thick. Transmissivity ranges from 220 to 280 square meters per day $\left(\mathrm{m}^{2} / \mathrm{d}\right)$ and the storage coefficient ranges from $9.75 \times 10^{-3}$ to $9.0 \times 10^{-5}$. Porosity ranges from 0.28 to 0.30 . The hydraulic gradient is estimated to be 0.006 and the pore velocity is estimated to be 0.18 meters per day $(\mathrm{m} / \mathrm{d})$ (Norvitch and others, 1973).

The Prairie du Chien-Jordan aquifer consists of the Prairie du Chien Group and the Jordan Sandstone (fig. 1). The Prairie du Chien Group is predominantly a light brownish-gray or buff, sandy, thin- to thick-bedded dolomite that is vuggy and fractured and contains some thin layers of interbedded grayish-green shale. The underlying Jordan Sandstone is a white to yellow, quartzose, fine- to coarse-grained sandstone that is massive or thick to thin bedded and varies from friable to well cemented. Despite the differing lithologies, the Prairie du Chien Group and Jordan Sandstone function as one aquifer because there is no regional confining unit between them. At the test site the aquifer is approximately $105 \mathrm{~m}$ below land surface and is $64 \mathrm{~m}$ thick. The average transmissivity is approximately $1,235 \mathrm{~m}^{2} / \mathrm{d}$, with a porosity of 0.3 . The hydraulic gradient is estimated to be 0.005 and the pore velocity is estimated to be $0.3 \mathrm{~m} / \mathrm{d}$ (Norvitch and Walton, 1979).

The St. Lawrence Formation is $170 \mathrm{~m}$ below land surface and is approximately $8 \mathrm{~m}$ thick. It is a gray and greenish-gray, laminated, thin-bedded, dolomitic siltstone, silty dolomite, and shale. The porosity ranges from 0.15 to 0.20 and transmissivities range from 1 to $10 \mathrm{~m}^{2} / \mathrm{d}$.
The Franconia-Ironton-Galesville aquifer consists of the Franconia Formation, and the Ironton and Galesville Sandstones. The Franconia Formation is divided into four members: Reno, Mazomanie, Tomah, and Birkmose (Walton and others, 1991). The Reno Member in the upper part of the Franconia is a fine- to very-fine-grained quartz and glauconitic sandstone. The Reno is divided into two sections located between 180 and $183 \mathrm{~m}$ and between 193 and $206 \mathrm{~m}$ below land surface. The Mazomanie Member in the upper part of the Franconia is located between the depths of 183 and $193 \mathrm{~m}$ below land surface. The Mazomanie also is a fine- to very-finegrained quartz sandstone but has minor glauconite content. The Tomah Member in the lower part of the Franconia is an interbedded sequence of fine- to veryfine-grained silty sandstone with interbedded siltstone or shale. The Tomah is located between 206 and $219 \mathrm{~m}$ below land surface. The Birkmose Member in the lower part of the Franconia is a dolomitic siltstone with some shale and fine- to very-fine-grained glauconitic sandstone interbedded. Based on the laboratory permeability tests (Walton and others, 1991), the horizontal hydraulic conductivity of the upper part of the Franconia is about 950 millidarcies compared to a value of about 6 millidarcies for the lower part of the Franconia. Thus, there are distinct differences in grain size and permeability between the upper and lower parts of the Franconia Formation. The Ironton Sandstone is white, mediumgrained, moderately well-sorted quartz arenite that contains some silt-sized material. The Galesville Sandstone consists of a white to light-gray slightly glauconitic, wellto moderately well-sorted, mostly medium-grained quartzose sandstone. The approximate depth and thickness of the Franconia-Ironton-Galesville aquifer beneath the site are $180 \mathrm{~m}$ and $61 \mathrm{~m}$, respectively. The transmissivity is approximately $35 \mathrm{~m}^{2} / \mathrm{d}$ and the storage coefficient ranges from $10^{-4}$ to $10^{-6}$ (Norvitch and Walton, 1979). Average porosity is approximately 0.25 with a hydraulic gradient of 0.002 and estimated pore velocity is $0.05 \mathrm{~m} / \mathrm{d}$ (Norvitch and others, 1973).

The Eau Claire Formation consists of interbedded siltstone, shale, and fine silty sandstone with a few thin layers of dolomite. The approximate depth and thickness of the formation beneath the site are $241 \mathrm{~m}$ and $30 \mathrm{~m}$, respectively. Transmissivity ranges from 0.5 to $5 \mathrm{~m}^{2} / \mathrm{d}$ and porosity ranges from 0.28 to 0.35 (Norvitch and others, 1973).

The Mount Simon-Hinckley-Fond du Lac aquifer consists of the Mount Simon, Hinckley, and Fond du Lac Sandstones. The Mount Simon Sandstone is fine to coarse grained, contains very thin beds of shale, and commonly is gray, white, or pink. The Hinckley Sandstone is fine to coarse grained and pale red to light pink. The Fond du Lac Sandstone contains lenticular beds of 
fine- to medium-grained arkosic sandstone interbedded with mudstone and is dark red to pink. The top of the aquifer is approximately $271 \mathrm{~m}$ below land surface, and the aquifer is approximately $60 \mathrm{~m}$ thick. The transmissivity is approximately $250 \mathrm{~m}^{2} / \mathrm{d}$ and the storage coefficient is about $6 \times 10^{-5}$ (Norvitch and others, 1973). The porosity averages 0.25 , the hydraulic gradient is 0.0025 , and the pore velocity is approximately $0.03 \mathrm{~m} / \mathrm{d}$ (Norvitch and others, 1973).

\section{AQUIFER SELECTION}

The selection of an aquifer for heat-storage testing was based on the following criteria: (1) minimal water use from the aquifer in the Twin Cities area, (2) adequacy of the confining units above and below the aquifer to contain the injected heated water, and (3) the hydrogeologic properties and natural gradients occurring within the aquifer and their effect to control the movement of heat.

The Franconia-Ironton-Galesville aquifer was selected based on the above criteria for the following reasons: (1) the aquifer is little used in the St. Paul area for water supply owing to its relatively low transmissivity and the availability of adequate supplies at shallower depths, (2) it is well confined above by the St. Lawrence Formation, a shale approximately $8 \mathrm{~m}$ thick, and below by the Eau Claire Formation, a siltstone and shale approximately $30 \mathrm{~m}$ thick, and (3) natural ground-water movement is slow due to low hydraulic gradients and transmissivity. Thus the potential is good for heat in the aquifer to be contained near the injection well.

\section{LOCATION OF PRODUCTION AND OBSERVATION WELLS}

The minimum spacing between injection and withdrawal wells in a doublet-well energy-storage system is directly related to the farthest distance heat will move from the injection well. If breakthrough of the thermal front from the injection well to the withdrawal well occurs during injection, the efficiency of the system will be reduced because the heat being injected simply will be circulated within the aquifer system and will not be stored.

Gringarten and Sauty (1975) describe an analytical solution for determining the minimum well spacing for temperature breakthrough in a doublet-well system as a function of injection rate, duration, thermal properties of the aquifer and the confining units, and porosity of the aquifer. They used the following assumptions in their solution:

1. The aquifer is of infinite areal extent, oriented horizontally, and of uniform thickness. It is confined above and below by layers that are impermeable and of infinite vertical extent.

2. Flow is steady, with a constant injection rate equal to the withdrawal rate, and all wells fully penetrate the aquifer.

3. Initially, the water and rock in all layers are at the same temperature. At time $t=0$, the temperature of the injected water is set equal to $T_{i}$, and maintained constant thereafter. Thermal equilibrium is assumed to take place instantaneously between rock and water.

4. There is no heat transfer by conduction in the horizontal directions in the aquifer or confining layers. All heat transport is by forced convection in the horizontal direction in the aquifer and by vertical conduction above and below the aquifer.

5. Aquifer thermal and hydraulic characteristics are constant and differences in viscosity between injected and native water are insignificant.

Gringarten and Sauty (1975, p. 4962) express the minimum distance $(D)$ between the two wells as

$$
D=\left\{\frac{2 Q \Delta t}{\left(\phi+(1-\phi) \frac{\rho_{R} C_{R}}{\rho_{W} C_{W}}\right) h+\left[\left(\phi+(1-\phi) \frac{\rho_{R} C_{R}}{\rho_{W} C_{W}}\right)^{2} h^{2}+2 \frac{K_{R} \rho_{R} C_{R}}{\left(\rho_{W} C_{W}\right)^{2}} \Delta t\right]^{1 / 2}}\right\}^{1 / 2}
$$

where

$$
Q=\text { injection rate }\left[l^{3} / t\right]\left(\mathrm{cm}^{3} / \mathrm{s}\right) \text {, }
$$$$
\Delta t=\text { duration of injection }[t](\mathrm{s}) \text {, }
$$$$
\phi=\text { aquifer porosity [dimensionless], }
$$

$\rho_{R} C_{R}=$ heat capacity of upper confining layer $\left[\left(E / l^{3}\right) / T\right]\left(\left(\mathrm{cal} / \mathrm{cm}^{3}\right) /{ }^{\circ} \mathrm{C}\right)$,

$\rho_{W} C_{W}=$ heat capacity of water $\left[\left(E / l^{3}\right) / T\right]\left(\left(\mathrm{cal} / \mathrm{cm}^{3}\right) /{ }^{\circ} \mathrm{C}\right)$, $K_{R}=$ thermal conductivity of upper confining layer $[((E / l) / t) / T)]\left(((\mathrm{cal} / \mathrm{cm}) / \mathrm{s}) /{ }^{\circ} \mathrm{C}\right)$, and

$h=$ aquifer thickness $[l](\mathrm{cm})$.

The unit of energy used by Gringarten and Sauty (1975) in equations 1 and 4 is calories, which will be used in this part of the report to remain consistent with their original work. To convert to the more commonly used energy unit, joule, which is used in the remainder of this report, multiply calorie by 4.187 .

The minimum doublet-well spacing for the FranconiaIronton-Galesville aquifer was determined for an injection rate of 75.6 liters per second $(\mathrm{L} / \mathrm{s})$ and duration of 4 months. This injection rate corresponds to an operational rate four times the short-term testing rate. The duration is the approximate time that surplus heat energy would be available from the university's steam-generating plant. The hydraulic and thermal properties needed for equation 1 are listed in table 1 . The thermal properties were obtained from Clark (1966).

Substituting values from table 1 into equation 1 results in a minimum well spacing of approximately $150 \mathrm{~m}$. To 
TABLE 1.-Hydraulic and thermal properties for determination of minimum doublet-well spacing and observation well locations

\begin{tabular}{ll}
\hline $\begin{array}{l}\text { Porosity of Franconia-Ironton- } \\
\text { Galesville aquifer }\end{array}$ & $=0.25$ \\
Heat capacity of Franconia-Ironton- & $=0.5743\left(\mathrm{cal} / \mathrm{cm}^{3}\right) /{ }^{\circ} \mathrm{C}$ \\
$\quad$ Galesville aquifer & $=0.4324\left(\mathrm{cal} / \mathrm{cm}^{3}\right) /{ }^{\circ} \mathrm{C}$ \\
Heat capacity of St. Lawrence & \\
Formation & $=1.00\left(\mathrm{cal} / \mathrm{cm}^{3}\right) /{ }^{\circ} \mathrm{C}$ \\
Heat capacity of water & $((\mathrm{cal} / \mathrm{cm}) / \mathrm{s}) /{ }^{\circ} \mathrm{C}$ \\
Thermal conductivity of St. Lawrence & $=6.5 \times 10^{-3}$ \\
Formation & $=61 \mathrm{~m}$ \\
Thickness of Franconia-Ironton- & \\
Galesville aquifer &
\end{tabular}

accommodate physical restrictions of well locations and to take advantage of existing underground utility corridors at the test site, the final production well spacing was chosen as $250 \mathrm{~m}$. With this spacing, temperature breakthrough described by Gringarten and Sauty (1975) did not reduce aquifer efficiency.

Observation wells were located by assuming that the injected water flowed radially outward from the production wells. The shape of the flow resembles a cylinder whose volume is

$$
V=Q t=\pi r^{2} h \phi
$$

where

$$
\begin{aligned}
V= & \text { volume }\left[l^{3}\right]\left(\mathrm{m}^{3}\right), \\
Q= & \text { rate of injection }\left[l^{3} / t\right]\left(\mathrm{m}^{3} / \mathrm{s}\right), \\
t= & \text { duration of injection }[t](\mathrm{s}), \\
r= & \text { distance of injected water from well bore }[l] \\
& (\mathrm{m}), \\
h= & \text { aquifer thickness }[l](\mathrm{m}), \text { and } \\
\phi= & \text { aquifer porosity }[\text { dimensionless }] .
\end{aligned}
$$

Assuming heat is transported mainly by convection with the injected water, the approximate location of the temperature front can be calculated from equation 2 by solving for $r$

$$
r=\left(\frac{Q t}{\pi h \phi}\right)^{1 / 2}
$$

Substituting the test-injection rate of $18.9 \mathrm{~L} / \mathrm{s}$ and the aquifer thickness and porosity from table 1 , equation 3 was solved for the approximate location of the temperature front for various times during the proposed test cycles. The temperature fronts were calculated to be approximately $11.7 \mathrm{~m}$ and $16.5 \mathrm{~m}$ from the injection well for times of 4 days and 8 days respectively. Based on these distance approximations and physical space limitations around the test site, radial distances of $7 \mathrm{~m}$ and $14 \mathrm{~m}$ from the injection well were proposed for observation well locations.
Although equation 3 indicates that temperature fronts may pass the proposed 7- and 14-m observation well locations, the equation gives no indication of the magnitude of temperature that might be observed. Gringarten and Sauty (1975, p. 4958) give an analytical solution for one-dimensional heat flow within a streamtube in a doublet-well flow field. The assumptions in their equation are the same as those described earlier for calculating the minimum well spacing for a doublet-well system. The water temperature within the streamtube may be described as

$$
\frac{T_{o}-T(S, t)}{T_{o}-T_{i}}=\operatorname{erfc}\left[\frac{\left(\rho_{W} C_{W}\right)^{2}}{K_{R} \rho_{R} C_{R}}\left(\frac{q^{2}}{S}\right)\left(t-\frac{\rho_{A} C_{A}}{\rho_{W} C_{W}} \frac{h S}{q}\right)\right]^{-1 / 2}
$$

where

$T(S, t)=$ temperature of the aquifer within a streamtube at some time $(t)$ after injection started $[T]\left({ }^{\circ} \mathrm{C}\right)$,

$T_{o}=$ initial aquifer and confining layer temperatures before injection $[T]\left({ }^{\circ} \mathrm{C}\right)$,

$T_{i}=$ temperature of injected water $[T]\left({ }^{\circ} \mathrm{C}\right)$,

$q=$ flow rate within streamtube $\left[l^{3} / t\right]\left(\mathrm{m}^{3} / \mathrm{hr}\right)$,

$S=$ area of streamtube $\left[l^{2}\right]\left(\mathrm{m}^{2}\right)$,

$\rho_{A} C_{A}=$ heat capacity of aquifer $\left[\left(E / l^{3}\right) / T\right]\left(\left(\mathrm{cal} / \mathrm{cm}^{3}\right) /\right.$ ${ }^{\circ} \mathrm{C}$ ), and

erfc $=$ error function $=(1$-erf $)$

and the remaining variables have been defined previously. Assuming that flow near the injection-well bore is radial, and that the drawdown effects of the withdrawal well are negligible near the injection well, the area of a streamtube at the two proposed observation well distances of $7 \mathrm{~m}$ and $14 \mathrm{~m}$ can be solved as part of the area of a circle

$$
S=\frac{\pi r^{2}}{N}
$$

where

$S=$ area of streamtube $\left[l^{2}\right]\left(\mathrm{m}^{2}\right)$,

$r=$ radial distance from well $[l](\mathrm{m})$, and

$N=$ total number of streamtubes [dimensionless].

Equation 4 was solved for temperatures at radial distances of $7 \mathrm{~m}$ and $14 \mathrm{~m}$ for injection times of 4 days and 8 days, an injection rate of $18.9 \mathrm{~L} / \mathrm{s}$, $(68$ cubic meters per hour $\left.\left(\mathrm{m}^{3} / \mathrm{hr}\right)\right)$ and a temperature of $150^{\circ} \mathrm{C}$. Variables for equation 4 are listed in table 1 . The number of streamtubes for equation 5 was selected as 68 , which reduces the flow rate per streamtube $(q)$ to $1 \mathrm{~m}^{3} / \mathrm{hr}$. The initial aquifer and confining layer temperature is assumed to be $10^{\circ} \mathrm{C}$. The calculated values are shown in table 2 .

Table 2 indicates that appreciable temperature changes will occur at the two selected observation well distances during the 8-day injection test. Therefore, 
TABLE 2.-Calculated temperature values for radial distances of $7 m$ and $14 m$ at the end of 4 days and 8 days of injection

\begin{tabular}{lcc}
\hline \multirow{2}{*}{$\begin{array}{l}\text { Time } \\
\text { (days) }\end{array}$} & \multicolumn{2}{c}{ Distance (meters) } \\
\cline { 2 - 3 } & 7 & 14 \\
\hline 4 & $137^{\circ} \mathrm{C}$ & $127^{\circ} \mathrm{C}$ \\
8 & $149^{\circ} \mathrm{C}$ & $146^{\circ} \mathrm{C}$ \\
\hline
\end{tabular}

radial distances of $7 \mathrm{~m}$ and $14 \mathrm{~m}$ were selected for observation well locations near both the injection and withdrawal wells (fig. 2).

The location of observation well CM1, which was selected as a site for a future injection or withdrawal well, is approximately $280 \mathrm{~m}$ from production well $\mathrm{A}$.

\section{INSTRUMENTATION OF OBSERVATION WELLS}

Measurement points in each observation well were located to obtain temperature and pressure data in either the (1) injection zone (Franconia-Ironton-Galesville aquifer), (2) upper or lower confining units (St. Lawrence and Eau Claire Formations), or (3) upper or lower aquifers (Jordan and Mt. Simon Sandstones). Measurement instrumentation also was designed for easy removal and replacement in case of failure. Observation wells were completed as piezometer nests using combinations of 2.54-, 3.18-, or 5.08-cm-diameter well casings, depending on the type of instrumentation. Figure 3 illustrates the completion of individual observation wells and the location of measurement points in them. To minimize the potential for thermal convection within the well casing, the average distance between temperature-measurement points in wells with $5.08-\mathrm{cm}$-diameter casings was $6.5 \mathrm{~m}$.

Pressure transducers, which were used for all pressure measurements, were sealed gages with a pressure range of 0 to 1,724 kilopascals $(\mathrm{kPa})$ and a compensated temperature range of 10 to $121^{\circ} \mathrm{C}$. Accuracy was \pm 2 percent of the full-scale output over the compensated temperature range, or a maximum of $\pm 34 \mathrm{kPa}$ at $121^{\circ} \mathrm{C}$. Electrical output signal was from 4 to 20 milliamperes over the full scale.

All temperatures were measured using type "T" (copper versus copper-nickel) teflon-coated thermocouples. The range was from 0 to $315^{\circ} \mathrm{C}$ with an accuracy of \pm 0.4 percent for full scale or a maximum error of $1.3^{\circ} \mathrm{C}$ at $315^{\circ} \mathrm{C}$. Electrical output signal was from 0 to 15.76 millivolts over the full scale.

A total of 22 pressure transducers and 58 thermocouples were located at sites A and B. All data were transmitted through buried cables to a central data logger and stored on computer magnetic tape and paper tape. Data-reduction and display programs were con- structed to manipulate the raw data. Data recorded for each measurement point could be retrieved in the form of time and measurement tables or time versus measurement graphic plots. Czarnecki (1983) discusses the datareduction programs and describes their use.

\section{FIELD OBSERVATIONS}

\section{GEOPHYSICAL LOGGING}

Geophysical logs were made of the 12.38 -cm-diameter coreholes at sites A and B and of the $20.32-\mathrm{cm}$-diameter test hole at site C. The logs obtained included natural gamma, temperature, specific conductance, caliper, single-point resistivity, self-potential, and flowmeter. These data were used in conjunction with the core samples to determine aquifer and confining-bed lithology. Figure 4 illustrates natural gamma logs for coreholes at sites $\mathrm{A}$ and $\mathrm{B}$ and the test hole at site $\mathrm{C}$ and the self-potential and specific-conductance logs for the corehole at site A. Figure 5 illustrates the stratigraphy described from cores collected at sites A and B (Marcus Hoyer, Minnesota Geological Survey, written commun., 1980).

The similarity between the respective geophysical logs and core samples at sites A, B, and C indicate stratigraphic uniformity within the study area for the Franconia-Ironton-Galesville aquifer and the upper and lower confining units. These data also indicate that the aquifer and confining units are oriented horizontally. The natural gamma logs from sites $\mathrm{A}, \mathrm{B}$, and $\mathrm{C}$ indicate the presence of continuous, thin shale beds that also were correlated with the core samples. The natural-gamma $\log$ s also indicate a thick shale layer in the lower part of the Franconia Formation from approximately 70 to $80 \mathrm{~m}$ in altitude. This depth interval area corresponds to the lower Reno, Tomah, and Birkmose Members of the Franconia Formation. Geophysical-logging techniques also were used to estimate variations in porosity.

\section{PACKER TESTING}

Data from inflatable straddle-packer tests in coreholes at sites $\mathrm{A}$ and $\mathrm{B}$ were analyzed to determine values of relative horizontal hydraulic conductivity. Figure 6 illustrates the intervals tested in coreholes $\mathrm{AC} 1$ and $\mathrm{BC} 1$.

A 7.62-cm-diameter submersible pump was installed midway between the two inflatable packers. Packer testing consisted of inflating the two packers to form a sealed (packed) interval and pumping within the straddled interval at a constant rate. Pressures within the packed interval were measured during pumping to determine the relative horizontal hydraulic conductivity for 


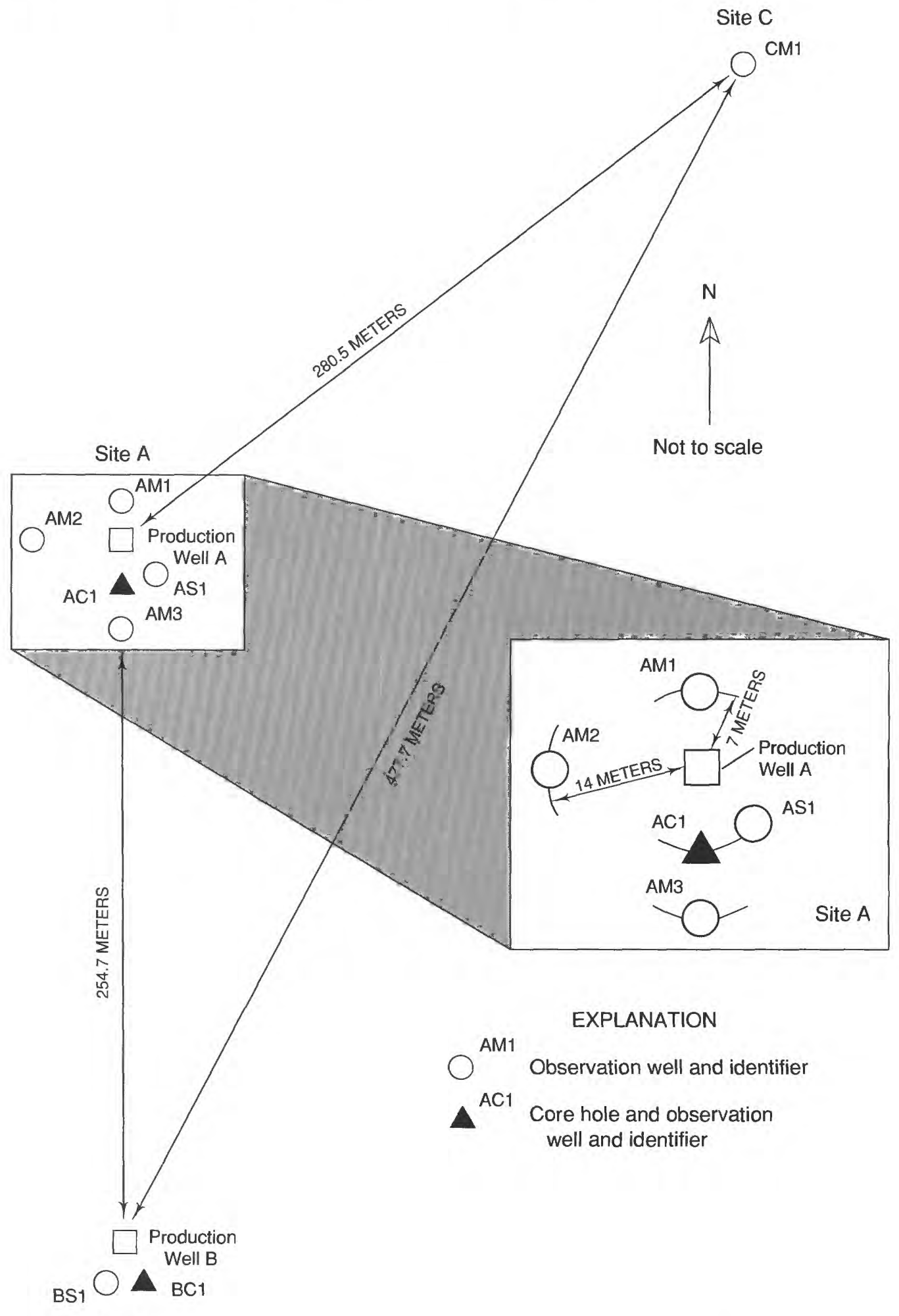

Site B

Figure 2.-Plan view of the Aquifer Thermal-Energy Storage (ATES) site. 
the interval. Pressures also were measured directly above and below the interval to determine whether a proper seal between the packer and the wall of the corehole had been obtained. Pumping time for packed intervals ranged from 5 to 20 minutes, depending on the measured rate of pressure change within the packed interval and on the measured pumping rate. Values of relative horizontal hydraulic conductivity and transmissivity for each packed interval were obtained based on the analysis of specific-capacity data.

Table 3 summarizes the specific-capacity, transmissivity, relative horizontal hydraulic conductivity, and packed interval for tests 1-8 in corehole AC1 and for tests 1-18 in corehole BC1. Values of transmissivity were calculated from the specific-capacity data for each packed interval with the methods described by Theis, Brown, and Meyer (1963) using a computer program developed by Czarnecki and Craig (1985). A storage coefficient of $2 \times 10^{-4}$ was assumed for all packed intervals.

Analysis of results of the packer tests indicated four hydraulic zones within the Franconia-Ironton-Galesville aquifer. Visual inspection of cores and analysis of borehole geophysical logs previously described were used to support and better define the location and thickness of each zone. Figures 5 and 7 shows the hydraulic zonation of the Franconia-Ironton-Galesville aquifer and the upper and lower confining units according to values of relative hydraulic conductivity.

\section{PRODUCTION WELL COMPLETION AND WELL-EFFICIENCY TESTING}

Based on the hydraulic zonation established from the analysis of geophysical logs and from inflatable packer testing, production wells A and B were screened in two intervals, the upper $14 \mathrm{~m}$ of the Franconia Formation and the $21 \mathrm{~m}$ of the Ironton and Galesville Sandstones. Figure 8 illustrates the screened intervals and well completion for production wells $\mathrm{A}$ and $\mathrm{B}$. The wirewound stainless steel, 10 -slot size screen was specially heat treated to withstand metal fatigue because of repeated contact with $150^{\circ} \mathrm{C}$ temperature water. The screen is set in a uniform gravel pack with an approximate grain size of $0.1 \mathrm{~cm}$. The well is steel cased from land surface to the top of the well screen in several steps from $130-\mathrm{cm}$ to $30.5-\mathrm{cm}$ inside diameter. A hightemperature silica cement was used to grout between the casing and the well bore.

Step-drawdown tests were made in production wells A and B immediately after well construction. Analysis of the data indicates that production well $\mathrm{B}$ was more efficient than production well A. Since the hydrogeologic properties are similar at both sites, the difference in well
TABLE 3.-Specific capacity, transmissivity, relative horizontal hydraulic conductivity, and interval tested for inflatable packer tests on coreholes $A C 1$ and $B C 1$

$\left[(\mathrm{L} / \mathrm{s}) / \mathrm{m}\right.$, liters per second per meter; $\mathrm{m}^{2} / \mathrm{d}$, square meters per day; $\mathrm{m}$, meters; $\mathrm{m} / \mathrm{d}$, meters per day; <, less than]

\begin{tabular}{|c|c|c|c|c|c|}
\hline Core hole & $\begin{array}{c}\text { Test } \\
\text { number }\end{array}$ & $\begin{array}{l}\text { Specific } \\
\text { capacity } \\
(\mathrm{L} / \mathrm{s}) / \mathrm{m}\end{array}$ & $\begin{array}{l}\text { Transmissivity } \\
\left(\mathrm{m}^{2} / \mathrm{d}\right)\end{array}$ & $\begin{array}{l}\text { Vertical } \\
\text { length } \\
\text { of interval } \\
\text { tested } \\
\text { (m) }\end{array}$ & $\begin{array}{c}\text { Relative } \\
\text { horizontal } \\
\text { hydraulic } \\
\text { conductivity } \\
(\mathrm{m} / \mathrm{d})\end{array}$ \\
\hline $\mathrm{AC} 1$ & 1 & 0.007 & $<0.186$ & 11.0 & $<0.017$ \\
\hline $\mathrm{AC} 1$ & 2 & .007 & $<.186$ & 11.0 & $<.017$ \\
\hline $\mathrm{AC} 1$ & 3 & .117 & 10.2 & 11.0 & .927 \\
\hline $\mathrm{AC} 1$ & 4 & .051 & 4.18 & 11.0 & .380 \\
\hline $\mathrm{AC} 1$ & 5 & \multicolumn{4}{|c|}{-- no discharge after 5 minutes pumping -- } \\
\hline $\mathrm{AC} 1$ & 6 & .373 & 32.5 & 126.5 & .250 \\
\hline $\mathrm{AC} 1$ & 7 & .373 & 28.8 & 75.3 & .382 \\
\hline $\mathrm{AC} 1$ & 8 & .032 & 3.53 & 11.0 & .320 \\
\hline BC1 & 1 & \multicolumn{4}{|c|}{-- no discharge after 5 minutes pumping - } \\
\hline $\mathrm{BC} 1$ & 2 & .039 & 3.26 & 6.40 & .509 \\
\hline BC1 & 3 & .269 & 26.6 & 73.2 & .363 \\
\hline BC1 & 4 & .168 & 15.9 & 6.4 & 2.48 \\
\hline $\mathrm{BC} 1$ & 5 & .153 & 14.5 & 6.4 & 2.25 \\
\hline BC1 & 6 & .109 & 10.0 & 6.4 & 1.57 \\
\hline BC1 & 7 & .149 & 14.1 & 60.0 & .578 \\
\hline $\mathrm{BC} 1$ & 8 & .261 & 25.7 & 48.8 & .527 \\
\hline $\mathrm{BC} 1$ & 9 & .008 & .576 & 6.4 & .089 \\
\hline BC1 & 10 & .002 & .123 & 6.4 & .019 \\
\hline BC1 & 11 & .002 & .123 & 6.4 & .019 \\
\hline $\mathrm{BC} 1$ & 12 & \multicolumn{4}{|c|}{--- no discharge after 5 minutes pumping - } \\
\hline $\mathrm{BC} 1$ & 13 & .012 & .873 & 6.4 & .136 \\
\hline BC1 & 14 & .159 & 15.1 & 6.4 & 2.36 \\
\hline BC1 & 15 & .035 & 2.87 & 6.4 & .449 \\
\hline BC1 & 16 & .002 & .123 & 6.4 & .019 \\
\hline BC1 & 17 & .143 & 13.5 & 6.4 & 2.11 \\
\hline BC1 & 18 & .594 & 61.9 & 97.5 & .635 \\
\hline
\end{tabular}

efficiencies probably was due to slightly different screen settings within the aquifer and differences in well development.

Production well A was developed using the pump-andsurge method for approximately 8 hours and was pumped at a maximum rate of $53.5 \mathrm{~L} / \mathrm{s}$ during development. The maximum drawdown measured after 3.0 hours of continuous pumping was approximately $75 \mathrm{~m}$ below the predevelopment static water level. After approximately 18 hours of recovery the water level was within $0.09 \mathrm{~m}$ of the predevelopment water level. This level was considered to be sufficient recovery to conduct a stepdrawdown test. Pumping durations and rates for the step-drawdown test were as follows: 202 minutes at 16.8 $\mathrm{L} / \mathrm{s}, 164$ minutes at $30.3 \mathrm{~L} / \mathrm{s}, 104$ minutes at $36.8 \mathrm{~L} / \mathrm{s}$, and 133 minutes at approximately $63 \mathrm{~L} / \mathrm{s}$. The pumping rate of the last step was estimated because the paddle-wheel type flow meter stopped working. The last step was not used in analysis of the test. 

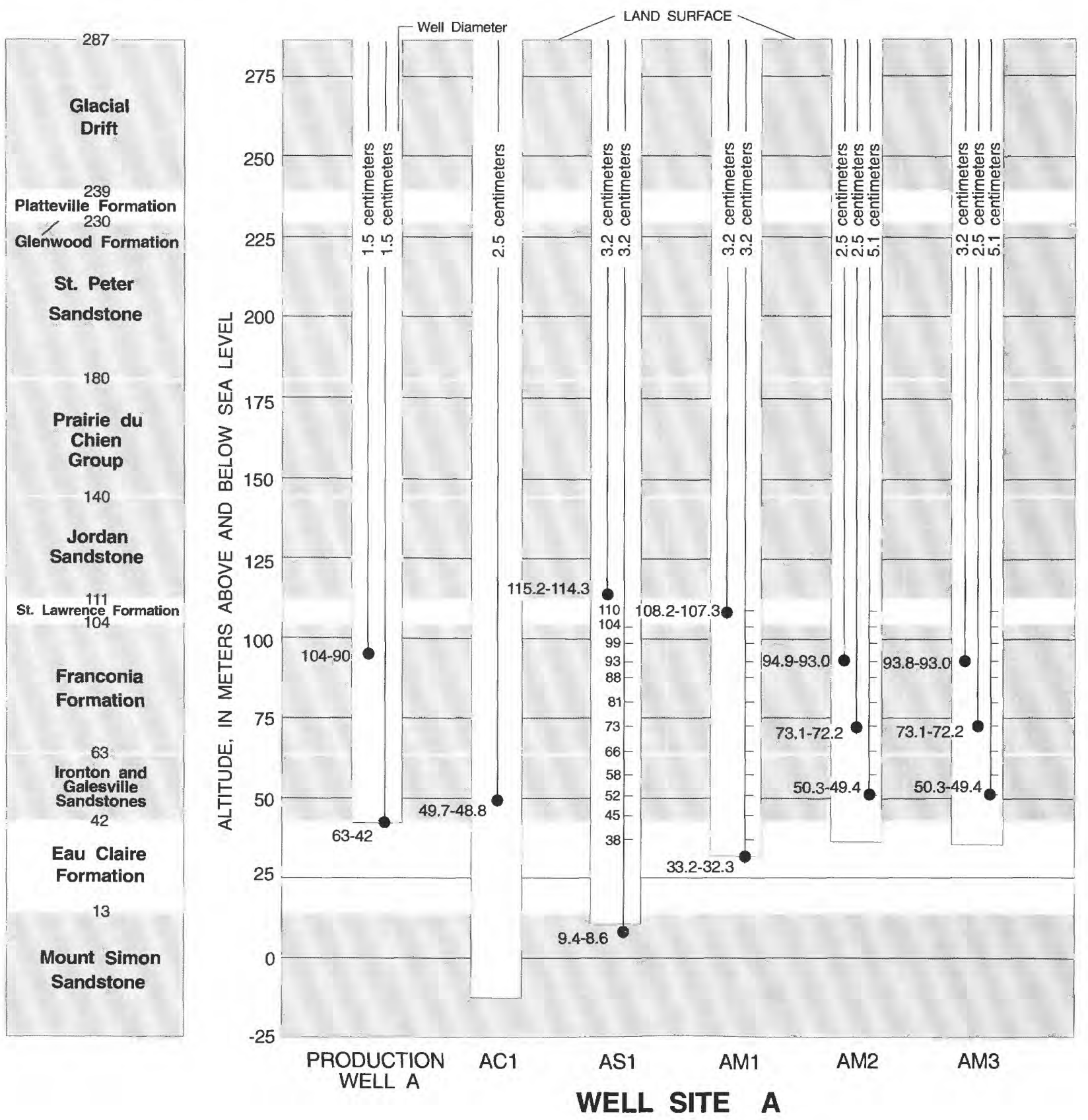

EXPLANATION

${ }_{114}-$ Temperature measurement point and altitude, in meters. (refer to well AS1 for measurement altitudes).

. $50-49$ Altitude of screened interval, in meters.

FIGURE 3.-Depths of observation well screened intervals and measurement point locations. 


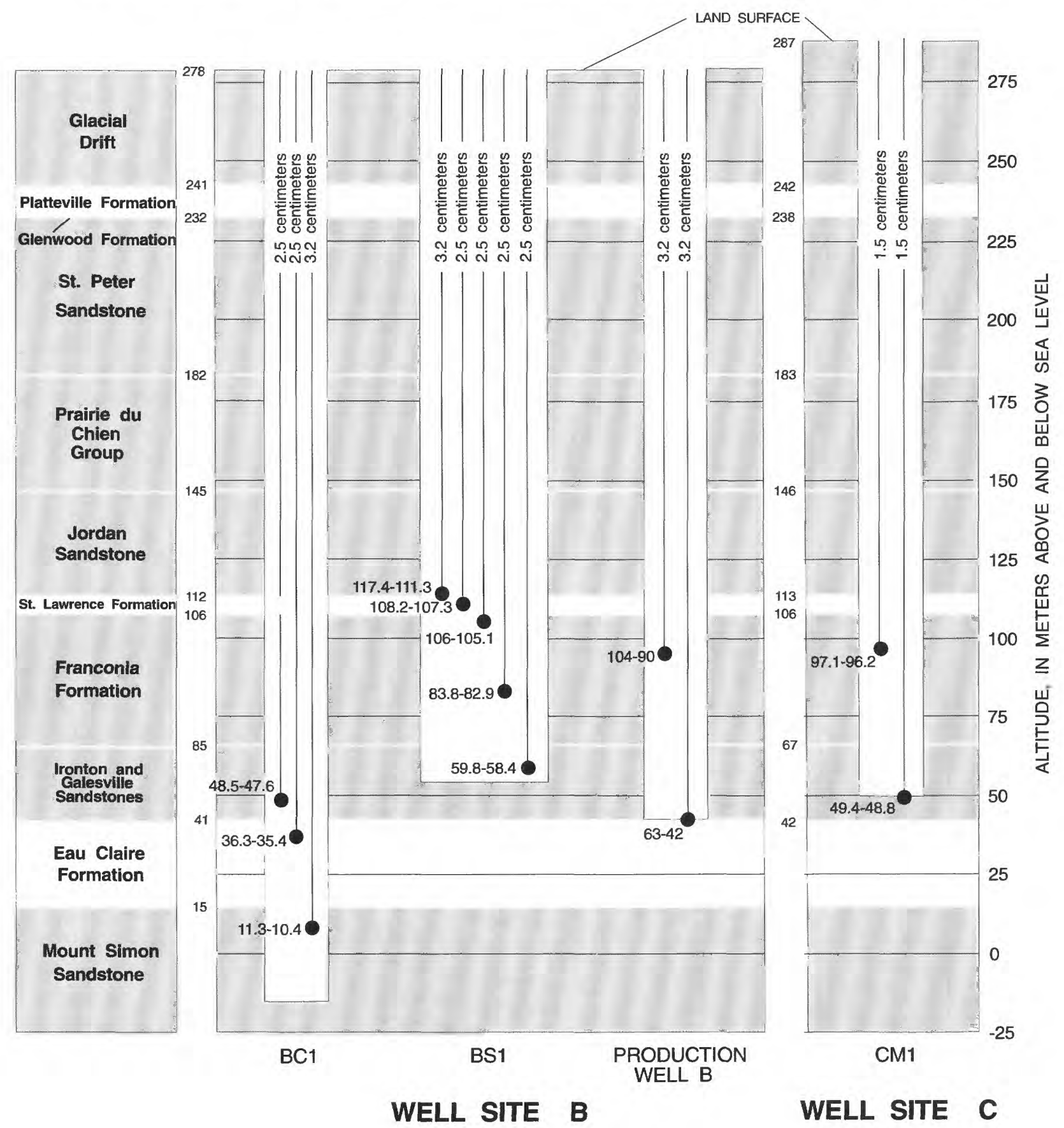

Figure 3.-Continued.

Production well B also was developed by the pumpand-surge method for approximately 10 hours. The maximum rate pumped during development of production well B was $53.6 \mathrm{~L} / \mathrm{s}$ for approximately 4.75 hours; maximum drawdown was approximately $78 \mathrm{~m}$ below the predevelopment static level. After approximately 12 hours of recovery, the water level was within $0.06 \mathrm{~m}$ of the predevelopment water level, which was considered to be sufficient recovery to conduct a step-drawdown test. Pumping durations and rates for the stepdrawdown test were as follows: 258 minutes at $13.9 \mathrm{~L} / \mathrm{s}$, 217 minutes at $24 \mathrm{~L} / \mathrm{s}$, and 190 minutes at $46.4 \mathrm{~L} / \mathrm{s}$. The drawdowns for step-drawdown tests of production wells $A$ and B are illustrated in figure 9.

Two methods were used to analyze data from the step-drawdown tests, a graphical method and an 


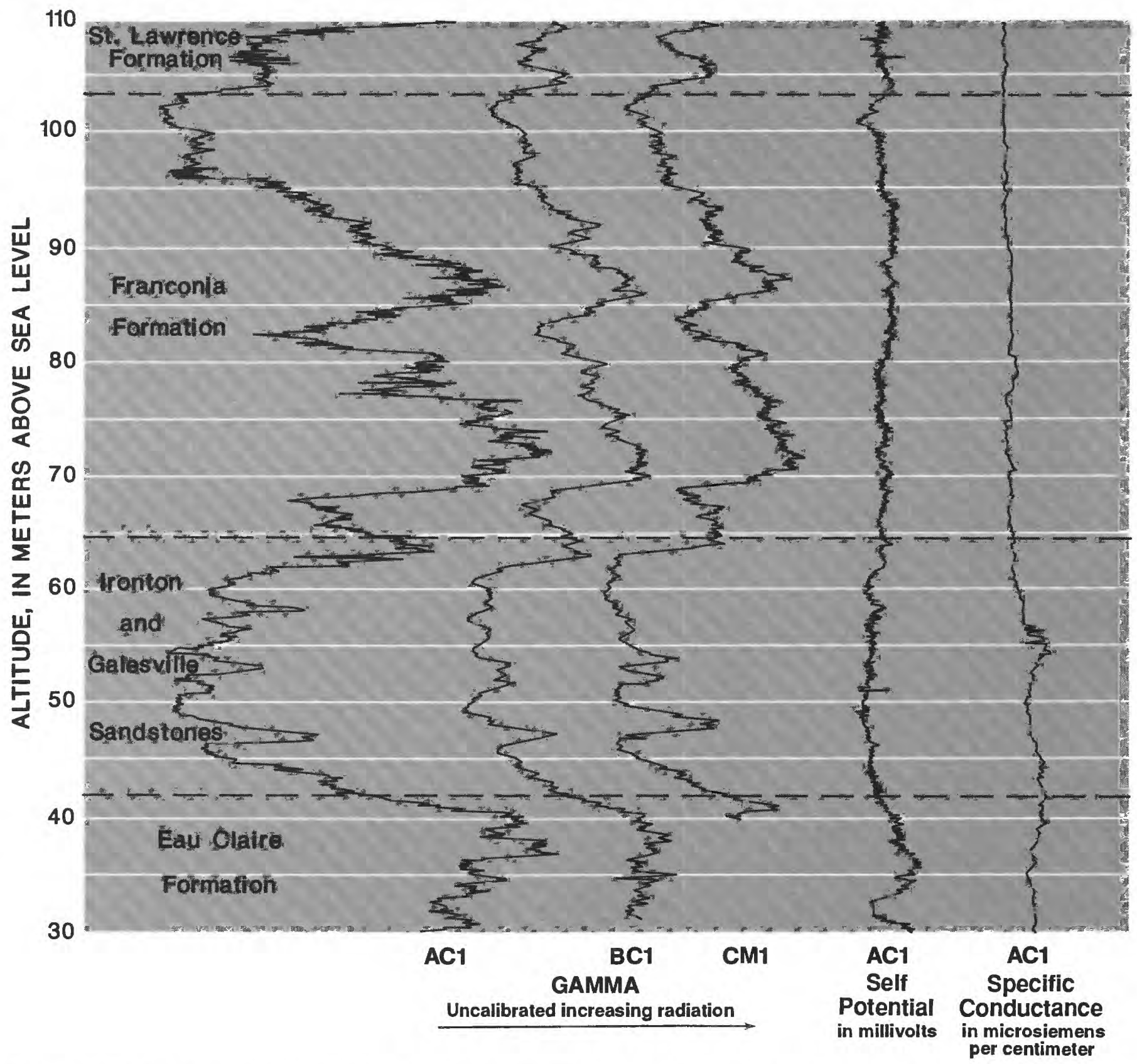

FIGURE 4.-Borehole geophysical logs of self potential, specific conductance, and natural gamma for corehole AC1 and natural gamma for corehole $\mathrm{BC} 1$ and observation well $\mathrm{CM} 1$.

optimization technique. The basic formula in the stepdrawdown test is (Rorabaugh, 1953; Labadie and Helweg, 1975, p. 439)

$$
S=B Q+C Q^{N}
$$

where

$S=$ drawdown in the well $[l](\mathrm{m})$,

$B=$ head-loss coefficient due to laminar flow in the aquifer,
$C=$ head-loss coefficient due to turbulent flow in the well bore,

$N=$ exponent that indicates the severity of turbulent head loss, and

$Q=$ discharge of well $\left[l^{3} / t\right](L / \mathrm{s})$.

For the graphical method, the value of $N$ was assumed to equal 2 (Rorabaugh, 1953). Values of $S / Q$ and $Q$ were plotted on rectangular coordinate paper. A straight line was drawn between the plotted points and extended to the intersection of the $S / Q$ axis. The intersection value 


\section{HYDRAULIC ZONES}

Horizontal
hydraulic

conductivity

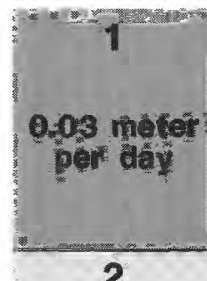

2

\subsection{1 meter per day}

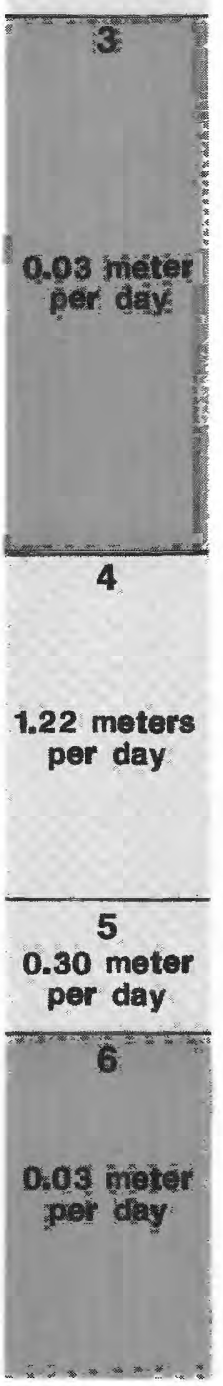

\section{CORES}

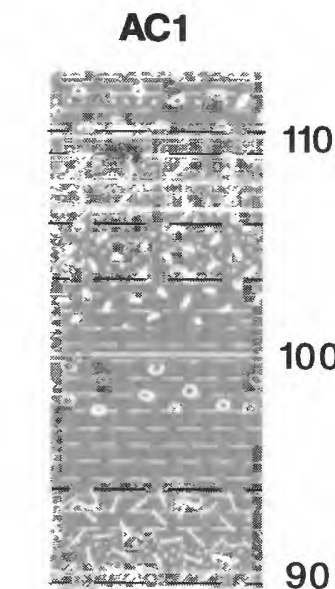

虫

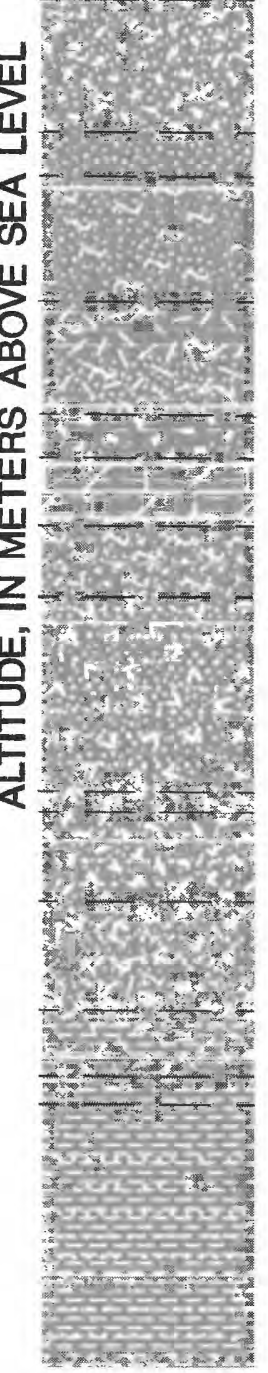

10

80

70

50

40

\section{LITHOLOGIES}

\section{BC1}

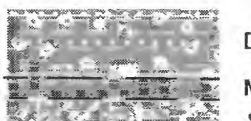

\section{(1)}

Silty dolomite, dolomitic siltstone, and intraclastic conglomerate.

FRANCONIA FORMATION

Fine and very fine glauconitic feldspathic sandstone.

Fine dolomitic feldspathic sandstone, intraclastic conglomerate, and thin shale. Sparse glauconite, some friable zones.

Fine and very fine glauconitic feldspathic sandstone and siltstone. Highly burrowed.

Silty and sandy dolomite.

Fine and very fine glauconitic feldspathic sandstone and siltstone. Many beds burrowed at top

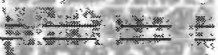

Fine clayey sandstone. "Mustard bed."

Fine highly glauconitic sandstone.

Interbedded fine and very fine glauconitic feldspathic sandstone and shale. Mottled and laminated beds.

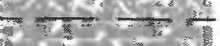

Interbedded fine silty feldspathic sandstone and shale.

Silty dolomite and dolomitic siltstone.

Fine glauconitic feldspathic sandstone, minor shale. Mottled and laminated beds.

\section{IRONTON AND GALESVILLE SANDSTONES}

Medium and coarse quartzose sandstone. Cross-bedded, some very friable zones.

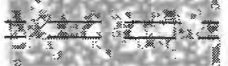

Fine quartzose sandstone with shale stringers.

Medium and fine quartzose and feldspathic sandstone with shale stringers.

Friable.

Fine and very fine feldspathic sandstone with shale stringers.

\section{EAU CLAIRE FORMATION}

Interbedded silty, very fine feldspathic sandstone and shale.

Shale.

Interbedded very fine sandstone and shale.

FIGURE 5. - Lithologies and hydraulic conductivities described from cores collected at coreholes AC1 and BC1. (Modified from Marcus Hoyer, Minnesota Geological Survey, written commun., 1980). 


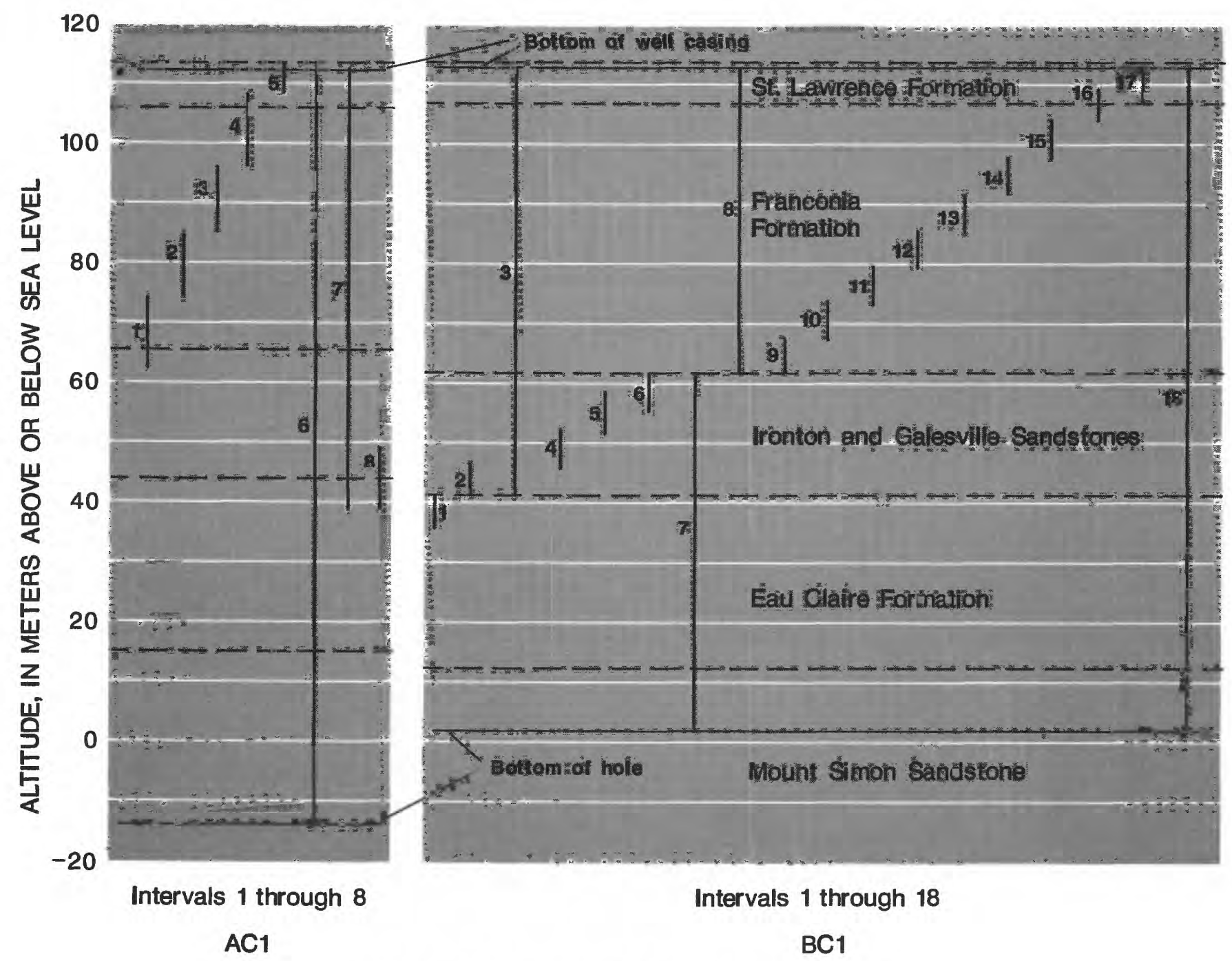

FIGURE 6. - Packer-test intervals for coreholes AC1 and BC1.

corresponds to the coefficient $B$ and the slope of the line corresponds to the coefficient $C$. This method and the resulting coefficients, $B$ and $C$, for the tests on production wells $A$ and $B$ are shown in figure 10. Substituting the values of $B$ and $C$ into equation 6 yields, for production well $\mathrm{A}$

$$
S=0.854 Q+0.0154 Q^{2}
$$

and for production well $\mathrm{B}$

$$
S=1.132 Q+0.0037 Q^{2}
$$

Labadie and Helweg (1975) describe another method for calculating the coefficients of $B, C$, and $N$. They use a minimizing optimization technique that uses Cramer's Rule and a one-dimensional grid search to determine the coefficients. The parameter-determination problem described by equation 6 is formulated as an optimization problem (Labadie and Helweg, 1975, p. 440)

$$
\text { Minimize } E(B, C, N)=B, C, N \sum_{i=1}^{M}\left[\left(B Q_{i}+C Q_{i}^{N}\right)-S_{i}\right]^{2}
$$

where

$M=$ total number of pumping steps, $i=1,2, \ldots, \mathrm{M}$ [dimensionless],

$Q_{i}=$ discharge during step $i$ of the test $\left[l^{3} / t\right]$ $(\mathrm{L} / \mathrm{s})$,

$S_{\mathrm{i}}=$ drawdown observed after step $i$ of the test $[l](\mathrm{m})$, and

$E(B, C, N)=$ the squared fitting error as a function of chosen $B, C, N$ for given step-drawdown test data.

Using this method to solve for values of $B, C$ and $N$ and substituting these values into equation 6 yields, for production well A 


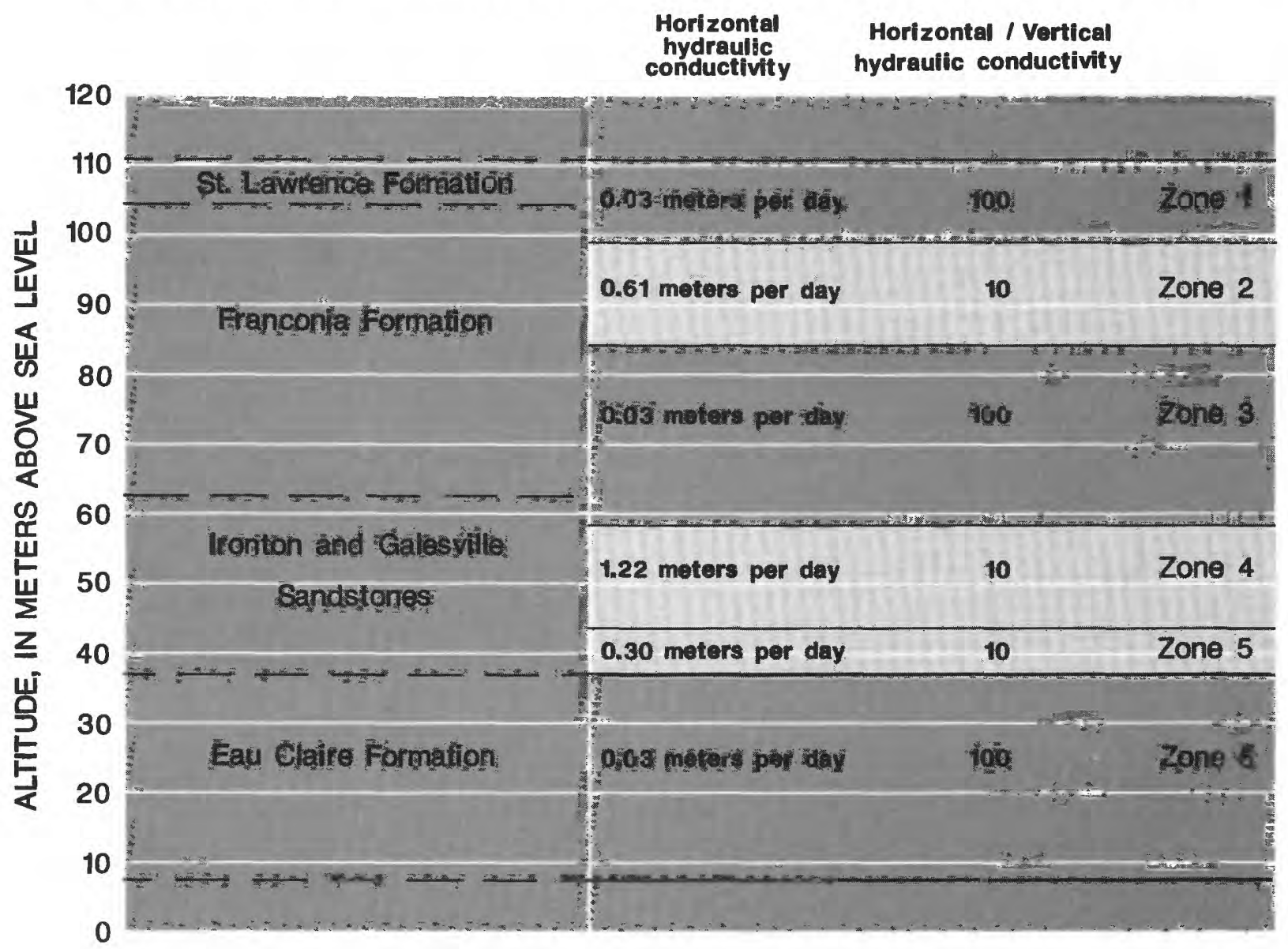

FIGURE 7. - Hydraulic zonation from the St. Lawrence Formation through the Eau Claire Formation based on interpretation of data from coreholes $\mathrm{AC} 1$ and $\mathrm{BC} 1$.

$$
S=1.046 Q+3.982 \times 10^{-4} Q^{2.888}
$$

and for production well B

$$
S=1.117 Q+7.899 \times 10^{-3} Q^{1.839}
$$

Comparison of the calculated drawdowns for various pumping rates from the two methods using equations 7 , 8,10 , and 11 for production wells A and B are shown in table 4.

Rorabaugh (1953) defined well efficiency as the ratio of the theoretical drawdown to the theoretical drawdown in the well minus the effects of turbulence. Well efficiencies can be calculated for various pumping rates from equation 6 by setting the head-loss coefficient (C) equal to zero and computing efficiency as $B Q / S$. The minimization equations 10 and 11 were used to calculate values of $B Q$ and $S$ for production wells $\mathrm{A}$ and B respectively. Table 5 summarizes values of $B Q, S$, and efficiency $(B Q / S)$ for various pumping rates for the wells.
TABLE 4.-Calculated drawdowns for various pumping rates for

\begin{tabular}{|c|c|c|c|c|}
\hline \multirow{3}{*}{$\begin{array}{l}\text { Rate (L/s) } \\
\text { (liters per } \\
\text { second) }\end{array}$} & \multicolumn{4}{|c|}{ Drawdown (m) } \\
\hline & \multicolumn{2}{|c|}{ Production well A } & \multicolumn{2}{|c|}{ Production well B } \\
\hline & $\begin{array}{c}\text { Graphical } \\
\text { (equation 7) }\end{array}$ & $\begin{array}{l}\text { Minimization } \\
\text { (equation 10) }\end{array}$ & $\begin{array}{c}\text { Graphical } \\
\text { (equation 8) }\end{array}$ & $\begin{array}{l}\text { Minimization } \\
\text { (equation 11) }\end{array}$ \\
\hline 6.3 & 6.0 & 6.7 & 7.3 & 7.3 \\
\hline 12.6 & 13.2 & 13.8 & 14.9 & 14.9 \\
\hline 18.9 & 21.6 & 21.7 & 22.7 & 22.9 \\
\hline 25.2 & 31.3 & 30.8 & 30.9 & 31.1 \\
\hline 31.5 & 42.2 & 41.4 & 39.3 & 39.7 \\
\hline 37.9 & 54.5 & 54.1 & 48.2 & 48.7 \\
\hline
\end{tabular}
production wells $A$ and $B$

TABLE 5. - Well efficiencies for production wells $A$ and $B$

\begin{tabular}{lcccccccc}
\hline $\begin{array}{l}\text { Rate (L/s) } \\
\text { (liters per } \\
\text { second) }\end{array}$ & \multicolumn{3}{c}{ Production well A } & & \multicolumn{3}{c}{ Production well B } \\
\cline { 2 - 4 } \cline { 6 - 8 } (meters) & $\begin{array}{c}S \\
\text { (meters) }\end{array}$ & $\begin{array}{c}\text { Efficiency } \\
\text { (percent) }\end{array}$ & $\begin{array}{c}S \\
\text { (meters) }\end{array}$ & $\begin{array}{c}B Q \\
\text { (meters) }\end{array}$ & $\begin{array}{c}\text { Efficiency } \\
\text { (percent) }\end{array}$ \\
\hline 6.3 & 6.7 & 6.6 & 98.8 & & 7.3 & 7.0 & 96.8 \\
12.6 & 13.8 & 13.2 & 95.6 & & 14.9 & 14.0 & 94.4 \\
18.9 & 21.7 & 19.8 & 91.1 & & 22.9 & 21.1 & 92.3 \\
25.2 & 30.8 & 26.4 & 85.6 & & 31.1 & 28.1 & 90.4 \\
31.5 & 41.4 & 32.9 & 79.6 & & 39.7 & 35.2 & 88.7 \\
37.9 & 54.1 & 39.6 & 73.3 & & 48.7 & 42.3 & 87.0 \\
\hline
\end{tabular}




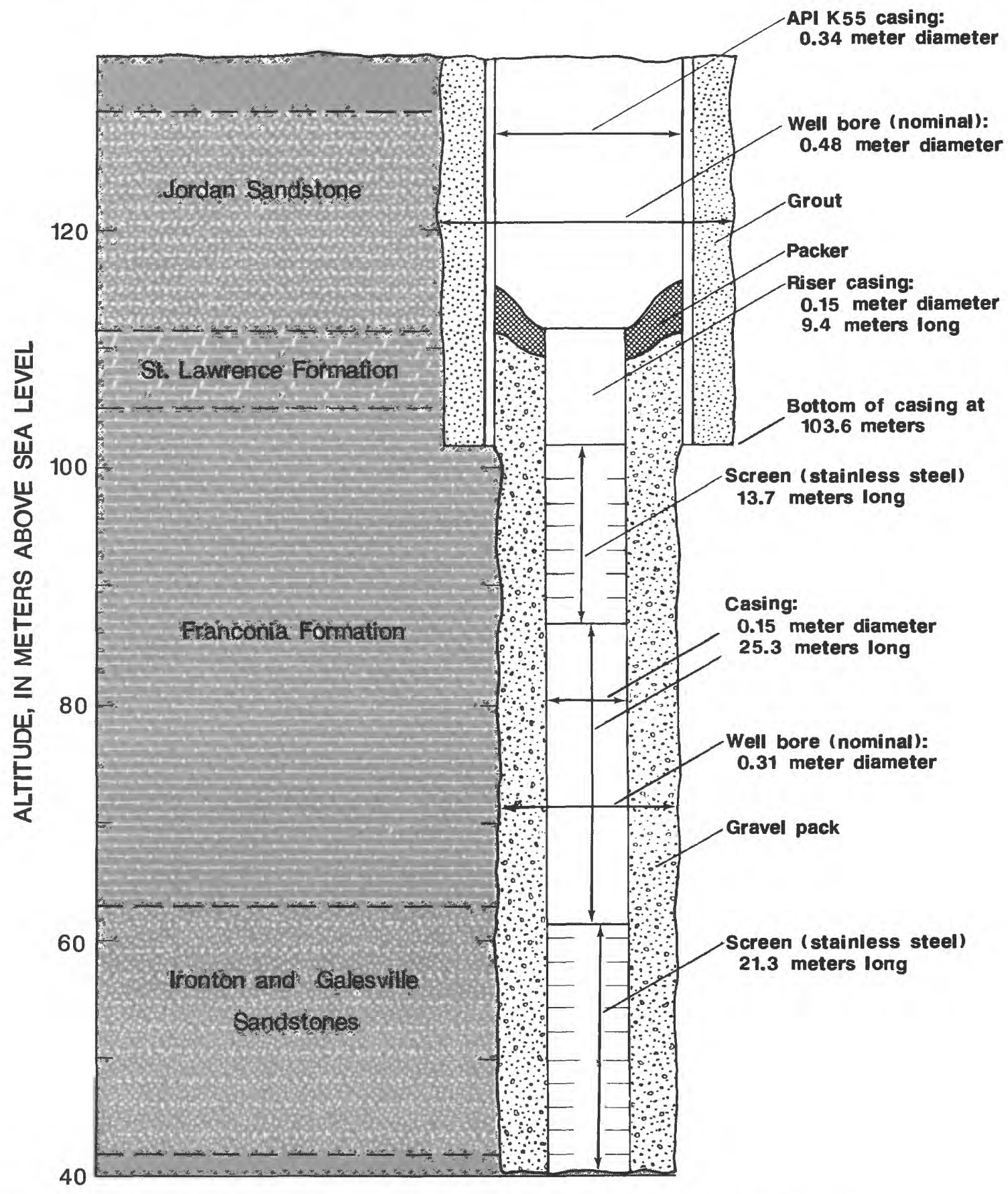

FIGURE 8.-Well completion and screened intervals for production wells A and B.

The lower efficiencies computed for production well A at the greater pumping rates could have been due to improper well construction or poor well development, because less time was spent developing production well A compared to production well $B$. The efficiency could improve with further testing. Nevertheless, the total drawdowns computed for both wells were close for the planned short-term test cycle rate of $18.9 \mathrm{~L} / \mathrm{s}$. A well efficiency of approximately 90 percent for a rate of 18.9
$\mathrm{L} / \mathrm{s}$ was not expected to affect system performance significantly during hot-water testing.

\section{HYDRAULIC PROPERTIES}

\section{ESTIMATES OF TRANSMISSIVITY FROM STEP-DRAWDOWN DATA}

Using the methods described by Harrill (1970), transmissivity was estimated using recovery data from the 

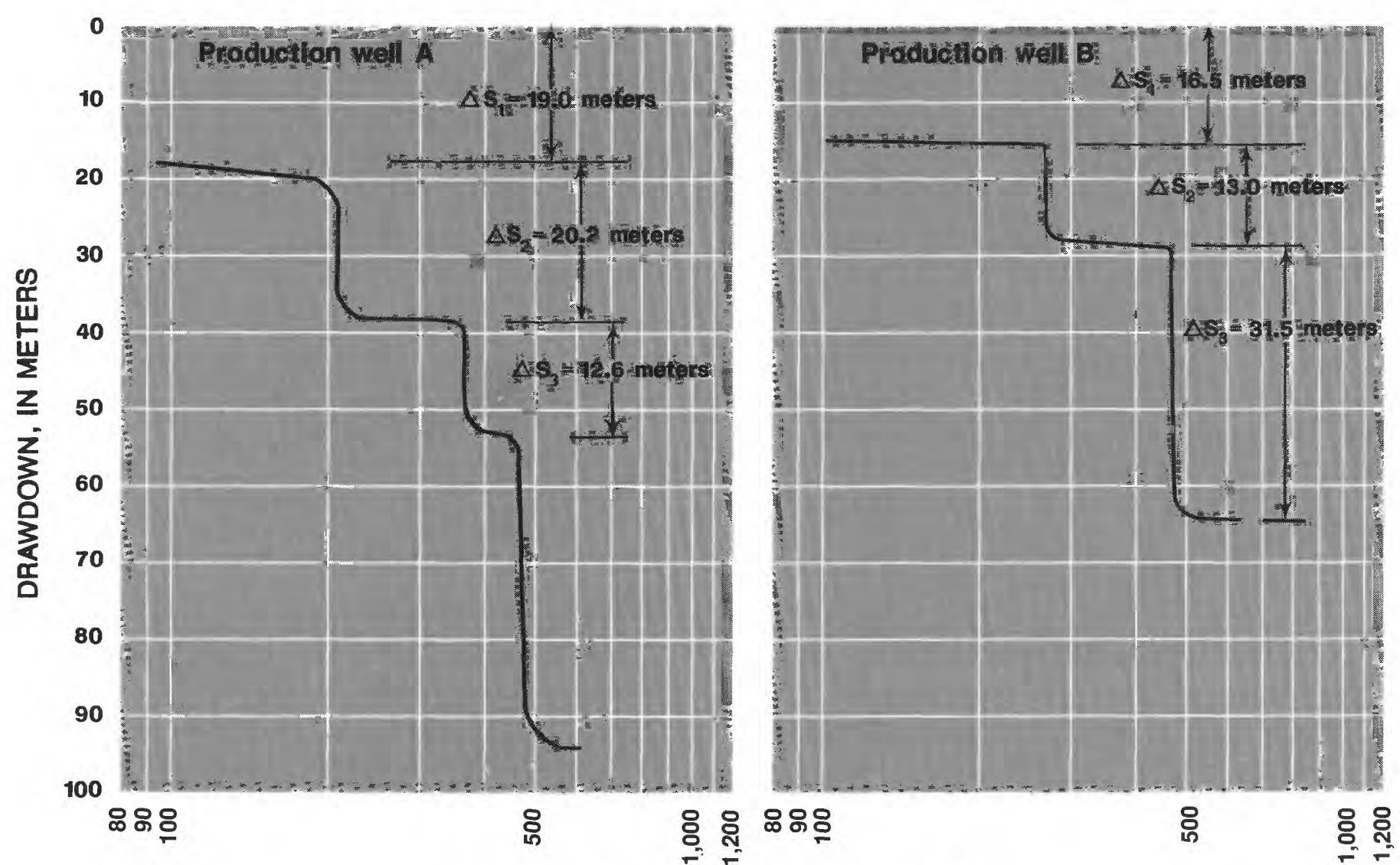

TIME, IN MINUTES FROM START OF TEST

Production well A

$\begin{array}{ccccc}\text { Step } & Q & \Delta S & S_{t} & S_{t} / Q \\ 1 & 16.842 & 19.0 & 19.0 & 1.128 \\ 2 & 30.278 & 20.2 & 39.2 & 1.295 \\ 3 & 36.839 & 12.6 & 51.8 & 1.406\end{array}$

Production well B

$\begin{array}{ccccc}\text { Step } & Q & \Delta S & S_{t} & S_{t} / Q \\ 1 & 13.878 & 16.5 & 16.5 & 1.189 \\ 2 & 23.970 & 13.0 & 29.5 & 1.231 \\ 3 & 46.395 & 31.5 & 61.0 & 1.315\end{array}$

\footnotetext{
Q, discharge in liters per second;

$\Delta S$, drawdown in meters;

$\mathbf{S}$, total drawdown in meters;

$S / Q$, total drawdown/discharge in meters

per liter per second
}

FIGURE 9. - Drawdowns for the step-drawdown tests conducted on production wells A and B.

step-drawdown test of production well B. Harrill's method is a modified form of the Theis recovery formula (Theis, 1935). On semilogarithmic paper, residual drawdown (S) is plotted against the corresponding stepdrawdown-test value of

$$
\frac{t_{1}\left(\frac{\Delta Q_{1}}{Q_{n}}\right) t_{2}\left(\frac{\Delta Q_{2}}{Q_{n}}\right) \ldots t_{n}\left(\frac{\Delta Q_{n}}{Q_{n}}\right)}{t^{\prime}}
$$

where

$t_{1}, t_{2}, \ldots t_{n}=$ elapsed times since the pump was turned on or discharge increased at each step, in days

$t^{\prime}=$ the elapsed time since the pump was turned off, in days,

$Q_{1}, Q_{2}, \ldots Q_{n}=$ the well discharge rates for each step in liters per day, and

$\Delta Q_{1}, \ldots \Delta Q_{2}, \Delta Q_{n}=$ the incremental increases in discharge between steps in liters per day. 


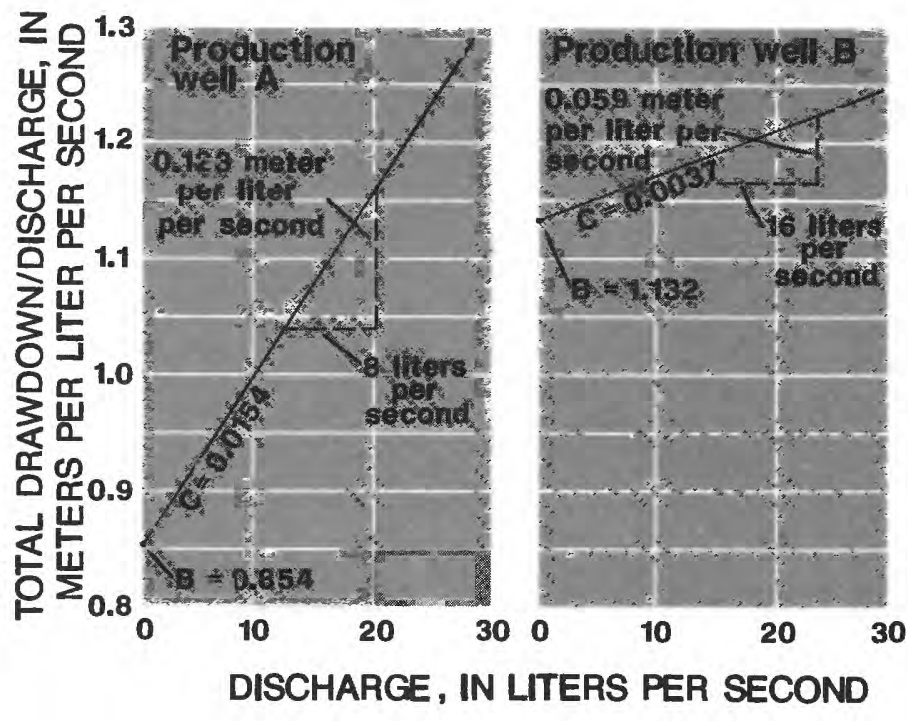

$B$, head-Ioss coefficient due to laminar flow in the aquifer in meters per liter per second

C, (slope) head-loss coefficient due to turbulent flow near the well in meters

FIGURE 10. - Relation of discharge to drawdown divided by discharge for step-drawdown test data from production wells A and B.
The value of $S$ is plotted on the arithmetic scale. After the value of $t^{\prime}$ is sufficiently large, the observed data fall on a straight line. If the value of equation 12 is chosen over one log cycle, its logarithm is unity and the transmissivity, in $\mathrm{m}^{2} / \mathrm{d}$, may be computed from

$$
T=\frac{1.83 \times 10^{-4} Q_{n}}{S}
$$

where $S$ is the change in residual drawdown in meters per log cycle of time (Harrill, 1970). Figure 11 illustrates the semilogarithmic plot of recovery data from the step-drawdown test at site B. Values of $S$ and transmissivity were computed as $6.7 \mathrm{~m}$ and $109.5 \mathrm{~m}^{2} / \mathrm{d}$, respectively.

The lack of a reliable determination of pumping rate during the fourth step of the step-drawdown test for production well A made calculation of the transmissivity by Harrill's (1970) method impossible. Instead, an estimation of the transmissivity was obtained using specificcapacity data computed from the first step. A specific capacity of 0.93 liters per second per meter $((\mathrm{L} / \mathrm{s}) / \mathrm{m})$ was calculated after 1 hour of pumping. Using this value, a transmissivity of $97.5 \mathrm{~m}^{2} / \mathrm{d}$ was computed based on curves from Walton (1981). This value is in agreement with the $109.5 \mathrm{~m}^{2} / \mathrm{d}$ calculated for production well $\mathrm{B}$.

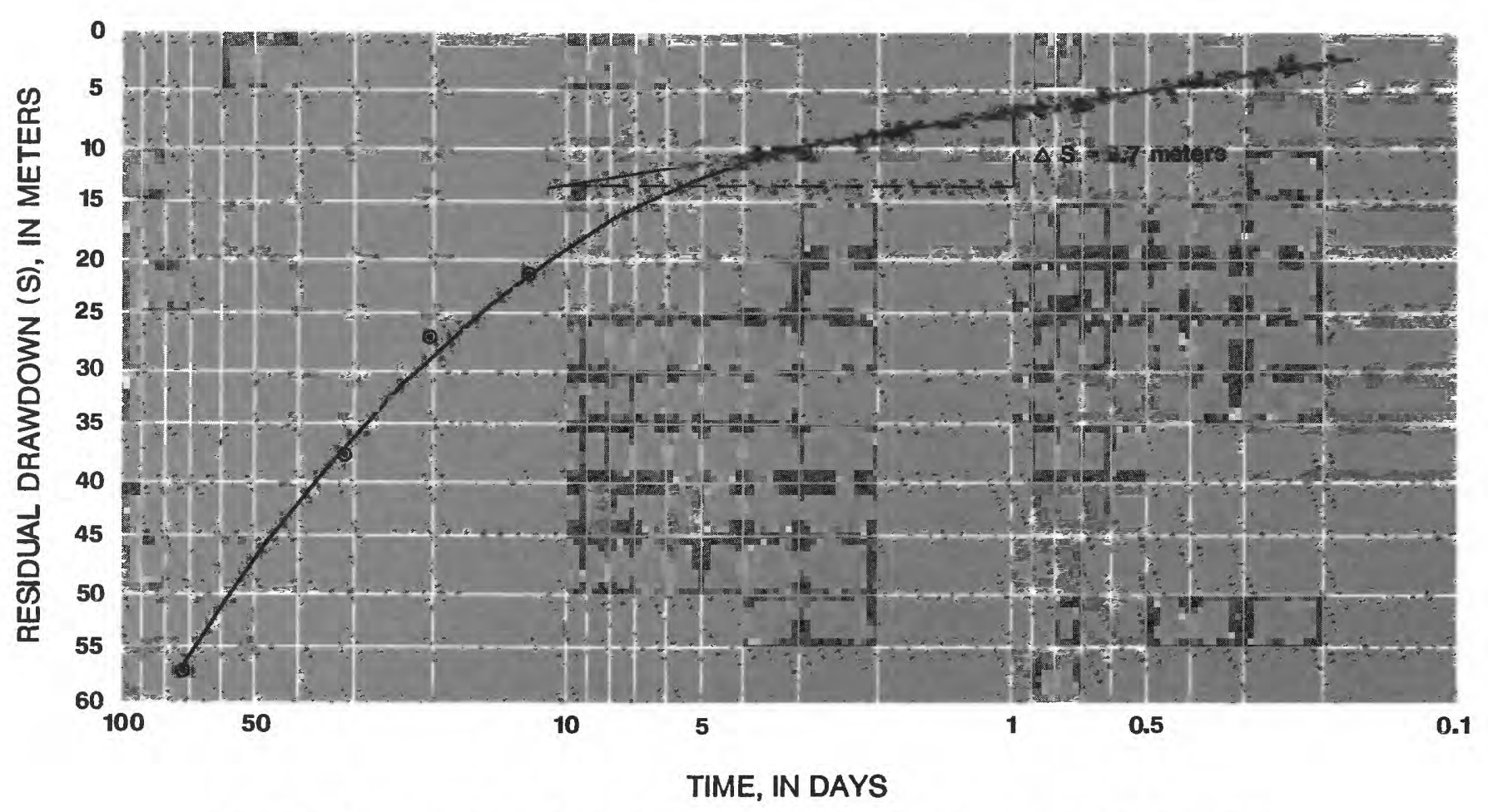

FIGURE 11. - Recovery of ground-water levels following the step-drawdown test at production well B. 


\section{ESTIMATES OF TRANSMISSIVITY AND AREAL ANISOTROPY FROM CONSTANT-RATE AQUIFER TESTS}

Two methods were used to analyze the aquifer-test data. The first method, described by Lohman (1972), was used to estimate the transmissivity and storage coefficient of a leaky confined aquifer with vertical movement. The second method, described by Papadopulos (1967), was used to estimate aquifer anisotropy.

A constant-rate aquifer test was conducted using production well A. The well was pumped for approximately 4.5 days at an average rate of $21.5 \mathrm{~L} / \mathrm{s}$. The pumping rate varied for the first 20 minutes of the test from 28.4 to $22.7 \mathrm{~L} / \mathrm{s}$ due to manual adjustment of a discharge-control valve. Pumping was interrupted twice during the latter part of the aquifer test for periods of no longer than 15 minutes because of water freezing in an automatic-cutoff pump-control pressure switch. These interruptions in pumping had negligible effects on analysis of the test data.

Time divided by radius squared was plotted versus drawdown on logarithmic graph paper for selected observation points in the upper part of the Franconia Formation and the Ironton and Galesville Sandstones. The resulting curves were matched against type curves developed by Cooper (1963). Match points were chosen, and values of transmissivity and storage coefficient were calculated as described by Lohman (1972). Table 6 summarizes the transmissivity and storage coefficient calculated for the selected observation points.

Averaging the transmissivity and storage-coefficient values in table 6 for each hydraulic zone gives a transmissivity for the Ironton and Galesville Sandstones of approximately $64.0 \mathrm{~m}^{2} / \mathrm{d}$ and a storage coefficient of $2.4 \times 10^{-5}$ and a transmissivity for the upper part of the Franconia Formation of $33.9 \mathrm{~m}^{2} / \mathrm{d}$ and a storage coefficient of $3.1 \times 10^{-5}$. Summing the two transmissivity values yields a total transmissivity of $97.9 \mathrm{~m}^{2} / \mathrm{d}$ for the Franconia-Ironton-Galesville aquifer, which is very close to the value of $97.5 \mathrm{~m}^{2} / \mathrm{d}$ for the aquifer at well site A calculated from analysis of specific-capacity data. The average storage coefficient is $2.75 \times 10^{-5}$.

The degree of anisotropy of the aquifer in the $\mathrm{x}-\mathrm{y}$ areal plane was determined using the type-curve method described by Papadopulos (1967) for nonsteady flow to a well in an infinite anisotropic aquifer. Miller (1984) describes in detail the determination of the $\mathrm{x}-\mathrm{y}$ areal plane anisotropy for the Franconia-Ironton-Galesville aquifer and examines the sensitivity of the results to errors in observation well locations. Miller's determination of the $\mathrm{x}-\mathrm{y}$ areal anisotropy is summarized below.

A rectangular-coordinate system was designed with the surface location of production well $\mathrm{A}$ as the origin, the $\mathbf{x}$ axis being a line east-west through the surface position of observation well AM2, and the $\mathrm{y}$ axis a line
TABLE 6. - Transmissivity in square meters per day $\left(m^{2} / d\right)$ and storage coefficient at selected observation points

\begin{tabular}{|c|c|c|c|}
\hline $\begin{array}{l}\text { Observation } \\
\text { well number }\end{array}$ & Aquifer hydraulic zone & $\begin{array}{l}\text { Transmissivity } \\
\left(\mathrm{m}^{2} / \mathrm{d}\right)\end{array}$ & $\begin{array}{c}\text { Storage } \\
\text { coefficient } \\
\text { (dimensionless) }\end{array}$ \\
\hline AM2 & $\begin{array}{l}\text { Upper part of the } \\
\text { Franconia Formation }\end{array}$ & 27.9 & $3.9 \times 10^{-5}$ \\
\hline AM2 & $\begin{array}{l}\text { Ironton and Galesville } \\
\text { Sandstones }\end{array}$ & 41.2 & $2.68 \times 10^{-5}$ \\
\hline AM3 & $\begin{array}{l}\text { Ironton and Galesville } \\
\text { Sandstones }\end{array}$ & 70.6 & $1.16 \times 10^{-5}$ \\
\hline CM1 & $\begin{array}{l}\text { Upper part of the } \\
\text { Franconia Formation }\end{array}$ & 28.8 & $1.04 \times 10^{-5}$ \\
\hline $\mathrm{BC1}$ & $\begin{array}{l}\text { Upper part of the } \\
\text { Franconia Formation }\end{array}$ & 45.1 & $4.28 \times 10^{-5}$ \\
\hline BC1 & $\begin{array}{l}\text { Ironton and Galesville } \\
\text { Sandstones }\end{array}$ & 80.4 & $3.46 \times 10^{-5}$ \\
\hline
\end{tabular}

north-south through the surface positions of observation wells AM1, AC1, and AM3. Figure 12 illustrates this coordinate system and shows the locations of observation wells at land surface and horizontal deviations at depth below land surface. Horizontal deviations with respect to depth are not shown for observation well AC1 because of the questionable results of the deviation survey on this well. Horizontal deviation surveys with respect to depth were not available for observation wells BS1, BC1, and CM1, but it is likely that they have similar deviations with depth.

Knowing the relative coordinates of three or more observation points, it is possible, using the methods outlined by Papadopulos (1967), to calculate values for the principal axes of a transmissivity ellipse and a corresponding direction of the principal axes related to a known rectangular coordinate system. Values were calculated for the Ironton and Galesville Sandstones with drawdown data from observation wells AM2, AM3, BC1, and CM1, and for the upper part of the Franconia Formation with data from observation wells AM2, BS1, and $\mathrm{BC} 1$ (fig. 12).

When data from more than three observation wells are available, they can be grouped into combinations of three. Data from the four observation wells in the Ironton and Galesville Sandstones were grouped into four sets, each containing data from three wells. Table 7 summarizes the grouping and assigns a corresponding set number.

Table 8 summarizes the computed major and minor transmissivity values, their corresponding directions, and the storage coefficients for the Ironton and Galesville Sandstones and the upper part of the Franconia Formation. The direction angles $(\theta)$ are measured from the $\mathrm{x}$-axis in figure 12 to the major axis of transmissivity, $\theta$ being positive in a counterclockwise direction. Summing the respective average major and minor transmissivities 

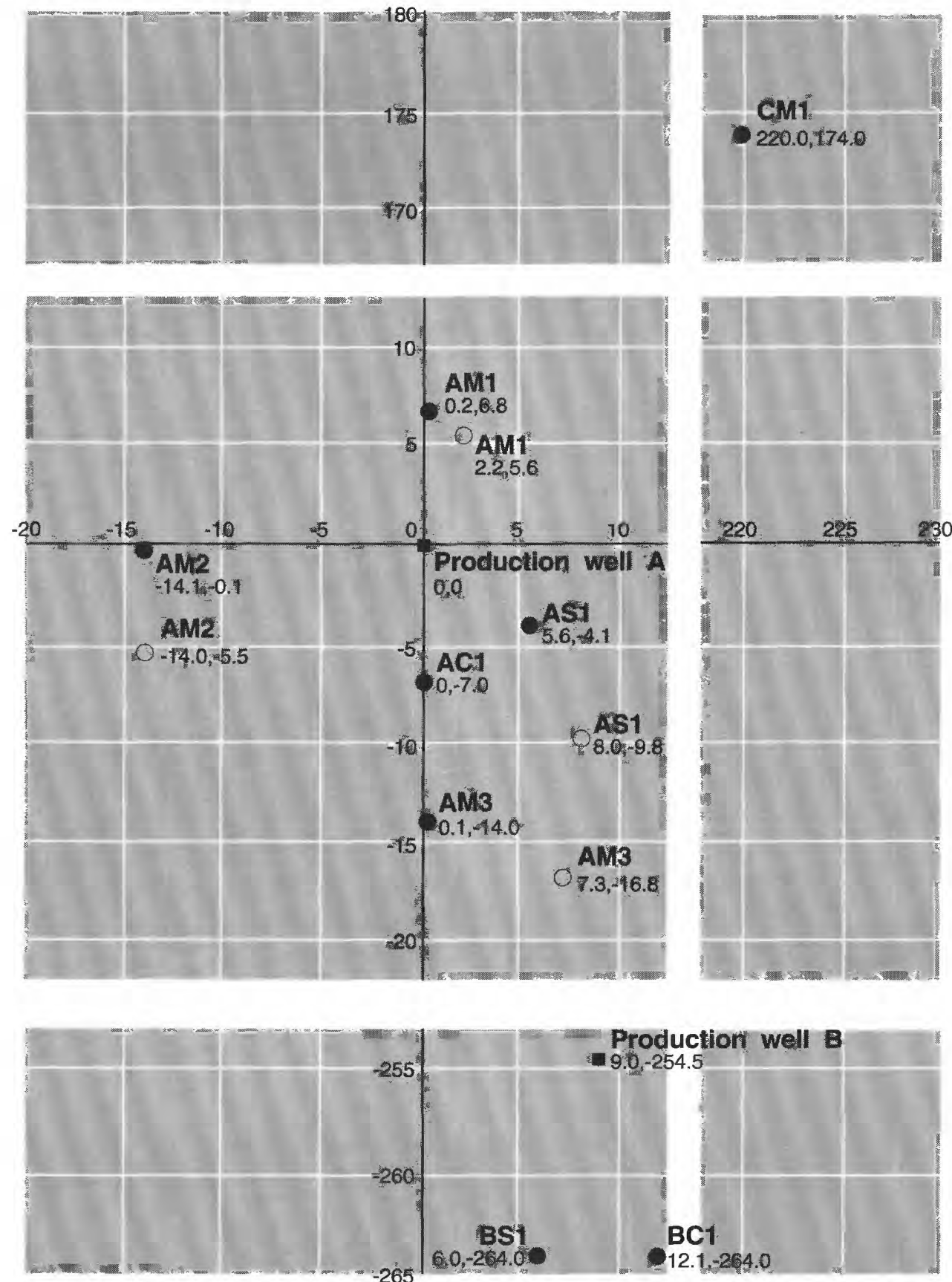

Coordinate system distances are

measured in meters from

production well $\mathrm{A}$

\section{EXPLANATION}

- Observation well

Well deviation at 234.7 meters below land surface

FIGURE 12.-Arbitrary coordinate system, in meters, indicating location and known deviation of production wells $\mathrm{A}$ and $\mathrm{B}$ and observation wells $\mathrm{AC1}$, AM1, AM2, AM3, AS1, BC1, BS1, and CM1. 
TABLE 7.-Observation-well combinations and corresponding set numbers used for determining aquifer anisotropy

\begin{tabular}{lcc}
\hline Aquifer hydraulic zone & $\begin{array}{c}\text { Set } \\
\text { number }\end{array}$ & $\begin{array}{c}\text { Observation wells } \\
\text { in set }\end{array}$ \\
\hline $\begin{array}{l}\text { Ironton and Galesville } \\
\text { Sandstones }\end{array}$ & 1 & $\mathrm{AM} 2, \mathrm{AM} 3, \mathrm{BC} 1$ \\
$\quad$ Do. & 2 & $\mathrm{AM} 2, \mathrm{AM} 3, \mathrm{CM} 1$ \\
Do. & 3 & $\mathrm{AM} 2, \mathrm{BC} 1, \mathrm{CM} 1$ \\
$\quad$ Do. & 4 & $\mathrm{AM}, \mathrm{BC1}, \mathrm{CM} 1$ \\
Upper part of the & 1 & $\mathrm{AM} 2, \mathrm{BS1}, \mathrm{BC} 1$ \\
Franconia Formation & & \\
\hline
\end{tabular}

TABLE 8.-Computed values of transmissivity, in square meters per day $\left(\mathrm{m}^{2} / \mathrm{d}\right)$, storage coefficient, and direction of major axis of transmissivity by set number

\begin{tabular}{|c|c|c|c|c|c|}
\hline \multirow{2}{*}{ Aquifer hydraulic zone } & \multirow{2}{*}{$\begin{array}{c}\text { Set } \\
\text { number }\end{array}$} & \multicolumn{2}{|c|}{$\begin{array}{l}\text { Transmissivity } \\
\left(\mathrm{m}^{2} / \mathrm{d}\right)\end{array}$} & \multirow{2}{*}{$\begin{array}{l}\text { Storage } \\
\text { coefficient }\end{array}$} & \multirow{2}{*}{$\begin{array}{c}\theta \\
\text { (degrees*) }\end{array}$} \\
\hline & & Major & Minor & & \\
\hline $\begin{array}{l}\text { Ironton and Galesville } \\
\text { Sandstones }\end{array}$ & 1 & 115.2 & 37.2 & $2.7 \times 10^{-5}$ & 64 \\
\hline Do. & 2 & 124.5 & 34.4 & $4.4 \times 10^{-5}$ & 71 \\
\hline Do. & 3 & 71.5 & 60.4 & $5.9 \times 10^{-5}$ & 67 \\
\hline \multirow[t]{2}{*}{ Do. } & 4 & 94.8 & 46.5 & $4.8 \times 10^{-5}$ & 76 \\
\hline & Average & 101.5 & 44.6 & $4.5 \times 10^{-5}$ & \\
\hline $\begin{array}{l}\text { Upper part of the } \\
\text { Franconia Formation }\end{array}$ & n & 40.0 & 24.0 & $3.7 \times 10^{-5}$ & 68 \\
\hline
\end{tabular}

* The direction of the major axis of transmissivity $(\theta)$ is an angle measured from the $\mathrm{x}$-axis positive in a counterclockwise direction.

for the Ironton and Galesville Sandstones and the upper part of the Franconia Formation and calculating the harmonic mean for the total average transmissivity yields a value of approximately $104.8 \mathrm{~m}^{2} / \mathrm{d}$. This value is very close to the transmissivity of $97.9 \mathrm{~m}^{2} / \mathrm{d}$ calculated with the method described by Lohman (1972) and 109.5 $\mathrm{m}^{2} / \mathrm{d}$ calculated with the step-drawdown recovery method described by Harrill (1970). Values of storage coefficient calculated with this method also are similar to those calculated by the method of Lohman (1972) given in table 6 .

\section{ESTIMATES OF EFFECTIVE POROSITY}

The porosity of the Franconia-Ironton-Galesville aquifer and the St. Lawrence Formation and Eau Claire Formation confining units were estimated from a combination of neutron borehole geophysical logs and from laboratory determinations of effective porosity of core samples.

Figure 13 shows a comparison between the naturalgamma and gamma-gamma density logs for observation well AM1 and the laboratory-determined value of effective porosity of core samples from corehole AC1. The neutron $\log$ indicates distinct zonation of the aquifer, related to values of porosity, by general shifts in the log.

At the approximate altitude from 98 to $104 \mathrm{~m}$, the neutron $\log$ indicates a shift toward higher porosity. Examination of the gamma-gamma density log at about the 98-m altitude also indicates a large shift to the right. Examination of well-driller's records suggests that the shift probably is caused by cement grout installed by the driller during observation-well completion. The effective porosity determined from laboratory analysis of core samples opposite the zone does not indicate a large increase in porosity, suggesting that the neutronporosity log may not be representative of the aquifer in this area; thus, this part of the log was disregarded in determining estimated porosity values.

To estimate effective-porosity values, a linear regression was performed on laboratory values of effective porosity, in percent, and the corresponding neutron value, in counts per second (cps), shown in figure 13 . The resulting linear equation for estimating effective porosity from neutron-log values is

$$
\phi=-0.0169 x+41.68
$$

where

$$
\begin{aligned}
& \phi=\text { effective porosity, and } \\
& x=\text { neutron-log value, in cps. }
\end{aligned}
$$

The average effective porosity was determined for the aquifer and confining layers using equation 14; values ranged from 0.25 to 0.31 .

\section{AMBIENT-TEMPERATURE WATER-INJECTION TESTING}

Ambient-temperature water-injection testing was conducted on production well $A$ at different injection rates to determine the ability of the aquifer to accept injected water and to obtain pressure data for isothermal-model calibration. Injection of water into production well A was designed to occur within the annular space between the well casing and pump-discharge column. Artificial recharge work by Sniegocki (1963), Foxworthy and Bryant (1967), Foxworthy (1970), and Reeder and others (1976) indicates that unless a positive pressure is maintained at the wellhead, entrainment of air in the injected water can effectively clog the well by reducing the hydraulic conductivity of the aquifer near the well bore. Pressures measured near the well head indicated that water flowing into the well entered at atmospheric pressure. Because a positive pressure was not maintained at the well head (the sound of water cascading inside the well was heard during the injection period), it is likely that air entrained in the injected water was responsible for clogging production well $\mathrm{A}$ during the first attempt at injection of ambient-temperature water. 


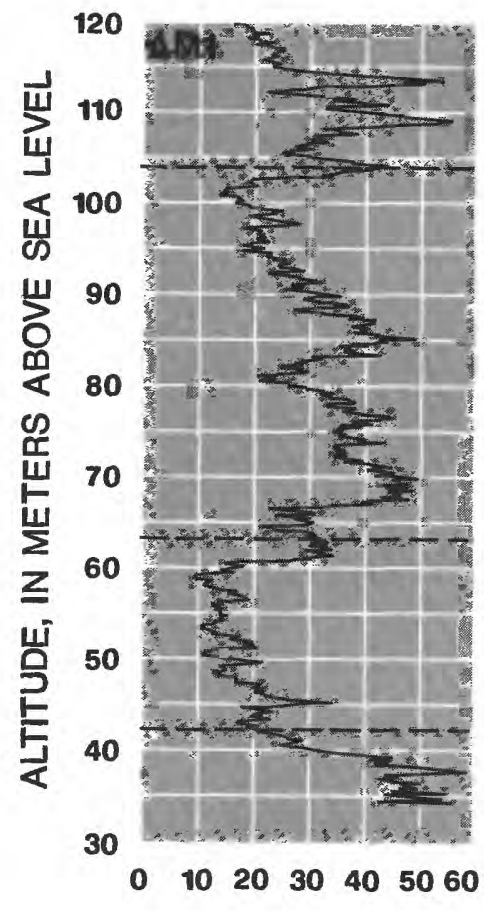

NATURAL GAMMA, IN COUNTS PER SECOND IN COUNTS PER SECOND

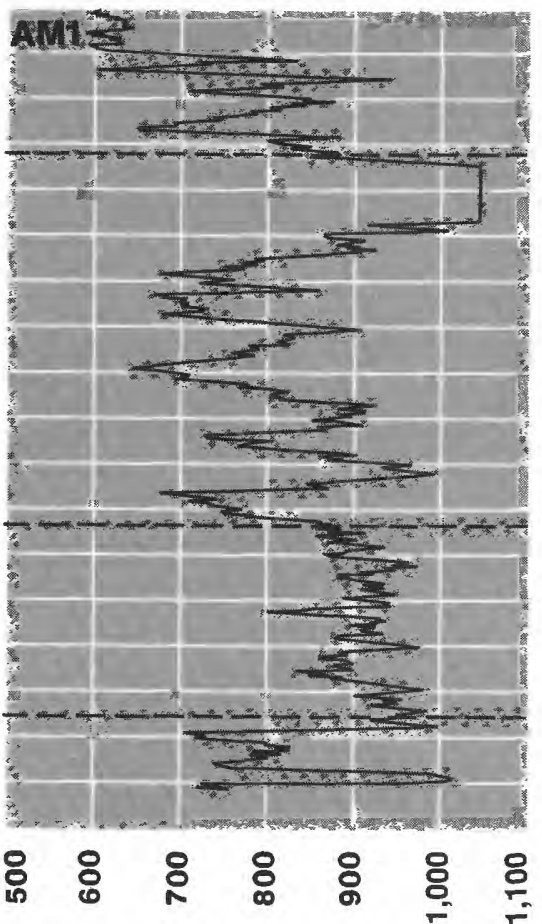

GAMMA-GAMMA,
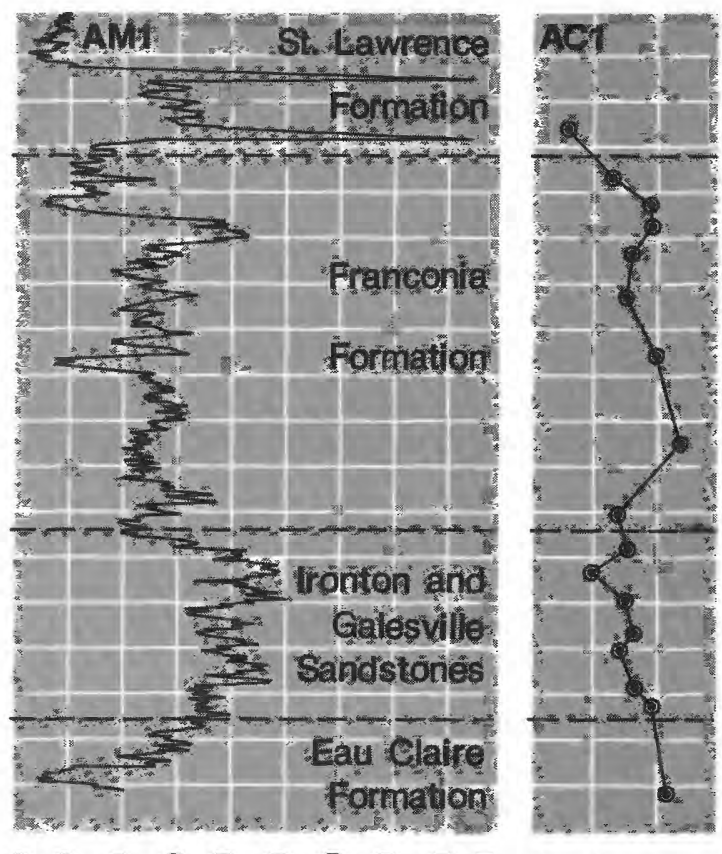

잉

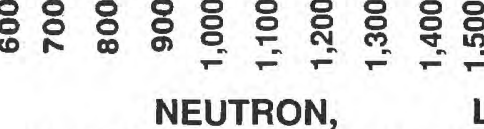
IN COUNTS PER SECOND

\section{LAB POROSITY,} IN PERCENT

FIGURE 13. - Natural gamma, neutron porosity, and gamma-gamma density logs with laboratory-determined values of effective porosity.

Water at a temperature of approximately $10^{\circ} \mathrm{C}$ was pumped from production well $\mathrm{B}$ at approximately 22.0 $\mathrm{L} / \mathrm{s}$ and injected into production well $\mathrm{A}$ at approximately $8.0 \mathrm{~L} / \mathrm{s}$. The remaining $14.0 \mathrm{~L} / \mathrm{s}$ from production well $\mathrm{B}$ was pumped to waste. Pumping to waste was necessary because of the large capacity of the pumps, which could be adjusted only by closing a series of valves. Closing the valves create back pressures in the above-ground piping that, for a pumping rate of $8.0 \mathrm{~L} / \mathrm{s}$, exceeded the designed safety standards of the valves. For pumping rates above $13 \mathrm{~L} / \mathrm{s}$, back pressure was not severe and diverting water to waste to maintain a specific injection rate was not necessary.

Figure 14 illustrates the pressure changes in production well A, the upper and lower parts of the Franconia Formation, and in the Ironton and Galesville Sandstones at observation well AM2 for approximately 1 day of injection at $8.0 \mathrm{~L} / \mathrm{s}$.

Adjustment of the injection rate during the early part of testing took approximately 30 minutes. This is shown in figure 14 in the step-pressure changes in production well A. Pressures continued to rise in the aquifer until about 150 minutes into injection when pressure declines started in production well $\mathrm{A}$ and in the upper part of the Franconia Formation and the Ironton and Galesville Sandstones. These pressure declines were a result of well interference caused by production well $\mathrm{B}$, which was pumping at approximately $22.0 \mathrm{~L} / \mathrm{s}$. Well-interference effects were measured in the observation well in the lower part of the Franconia Formation after approximately 300 minutes of injection. The pressure changes in the lower part of the Franconia Formation lag behind those in the upper part of the Franconia Formation and in the Ironton and Galesville Sandstones because (1) the lower part of the formation is cased off, thus, there is no direct injection or withdrawal in this part of the aquifer and (2) the lower part of the Franconia Formation has a considerably lower hydraulic conductivity than the upper part of the Franconia Formation or the Ironton and Galesville Sandstones.

After 1,440 minutes of injection at $8.0 \mathrm{~L} / \mathrm{s}$ the rate was increased to $18.9 \mathrm{~L} / \mathrm{s}$. Increasing the rate dropped back pressures in the above-ground piping substantially, which enabled withdrawals from production well B and injection into production well $A$ to be equal. Figure 15 illustrates pressure changes in production well $\mathrm{A}$ for the period at injection of $18.9 \mathrm{~L} / \mathrm{s}$. Pressures represent changes from the final pressure recorded after 1,440 minutes of injection at $8.0 \mathrm{~L} / \mathrm{s}$, as shown in figure 14 .

It took approximately 30 minutes from the start of injection at $18.9 \mathrm{~L} / \mathrm{s}$ to adjust the injection rate into production well A. Effects of the adjustment are 


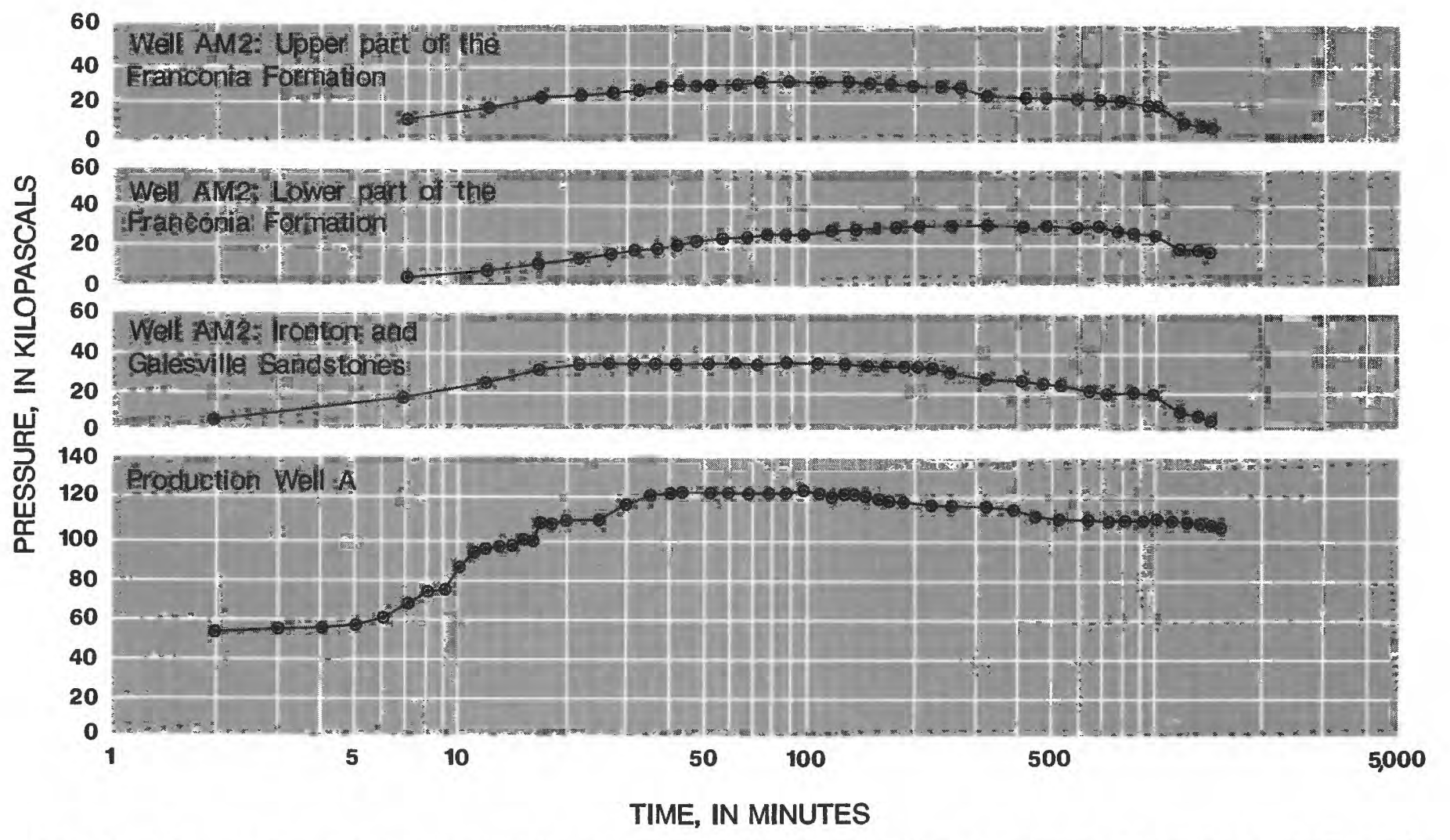

FIGURE 14.- Pressure changes for injection at 8.0 liters per second at observation well AM2 in the upper and lower parts of the Franconia Formation and in the Ironton and Galesville Sandstones and in production well A.

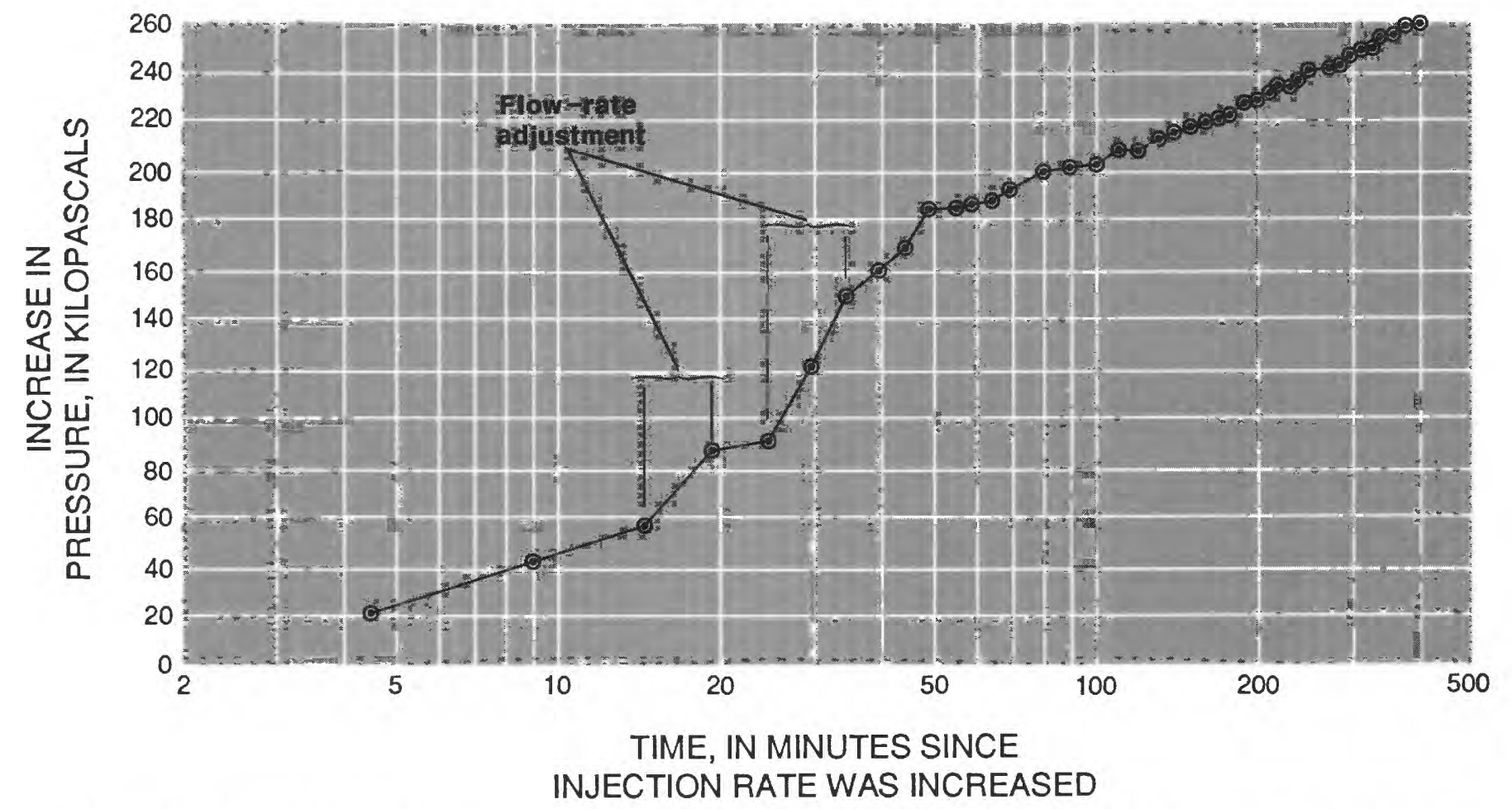

FIGURE 15. - Pressure changes in production well A at 18.9 liters per second after 1,440 minutes of injection at 8.0 liters per second. 

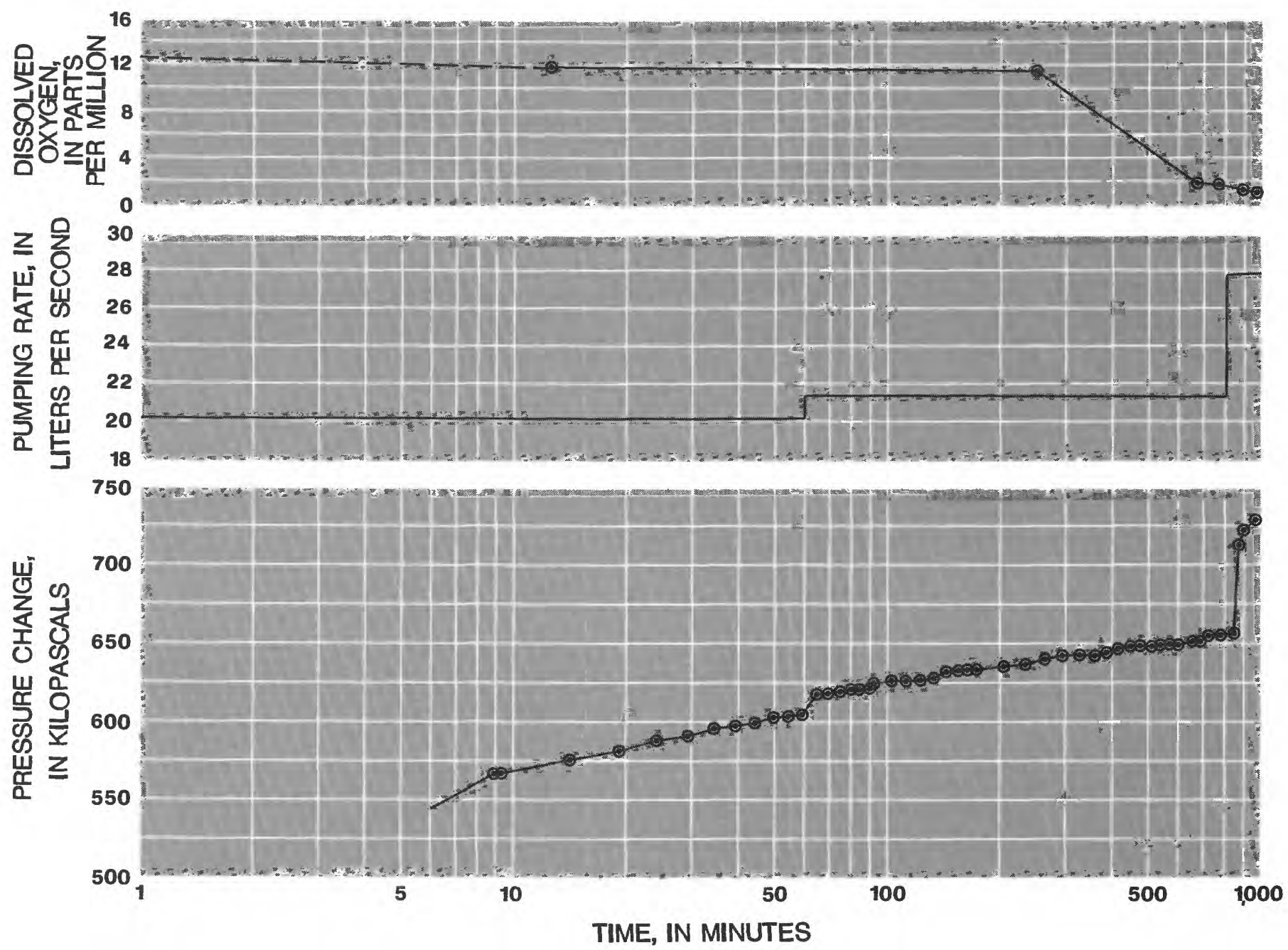

FIGURE 16. - Pressure change, pumping rate, and dissolved oxygen content during rehabilitation of production well A.

illustrated in figure 15 by the large pressure-step increases in production well A during the early part of the injection. Following the adjustment period, the pressure continued to rise steadily for the next 20 minutes, which probably was a combination of the effects of a higher injection rate into production well $\mathrm{A}$ and overcoming the interference effects from production well $\mathrm{B}$, in which the withdrawal rate was decreased from 22.0 to $18.9 \mathrm{~L} / \mathrm{s}$.

Pressures in production well A continued to increase. During the last 100 minutes of injection, the rate of change of pressure started to increase. This increase indicated potential clogging because of air entrained in the injection water. Therefore, after 400 minutes, injection was stopped before any further air entrainment clogging reduced the injection potential of the aquifer.

Water levels in production well A returned to within $0.30 \mathrm{~m}$ of preinjection levels after approximately 12 hours of recovery. Well rehabilitation consisted of pump- ing production well A continuously for approximately 18 hours, increasing the rate in three steps. Dissolvedoxygen levels were measured during redevelopment. The dissolved-oxygen concentrations in the injection water before injection were between 0.1 and 0.05 milligrams per liter (mg/L), were about $12 \mathrm{mg} / \mathrm{L}$ during redevelopment, and were between 0.5 and $0.1 \mathrm{mg} / \mathrm{L}$ after redevelopment. Figure 16 illustrates the pressure changes, pumping rate, duration, and dissolved-oxygen concentrations during redevelopment of production well A. Water levels were allowed to recover for approximately 8 days, at which time the water level in production well $\mathrm{A}$ was within $0.06 \mathrm{~m}$ of the preinjection level.

After 8 days of recovery, a second injection test was performed on production well $\mathrm{A}$. To reduce the potential for air entrainment, water was injected through the pump-discharge column. A positive pressure of approximately 1,030 kilopascals $(\mathrm{kPa})$ was maintained at the well head throughout the injection test, thus reducing the 


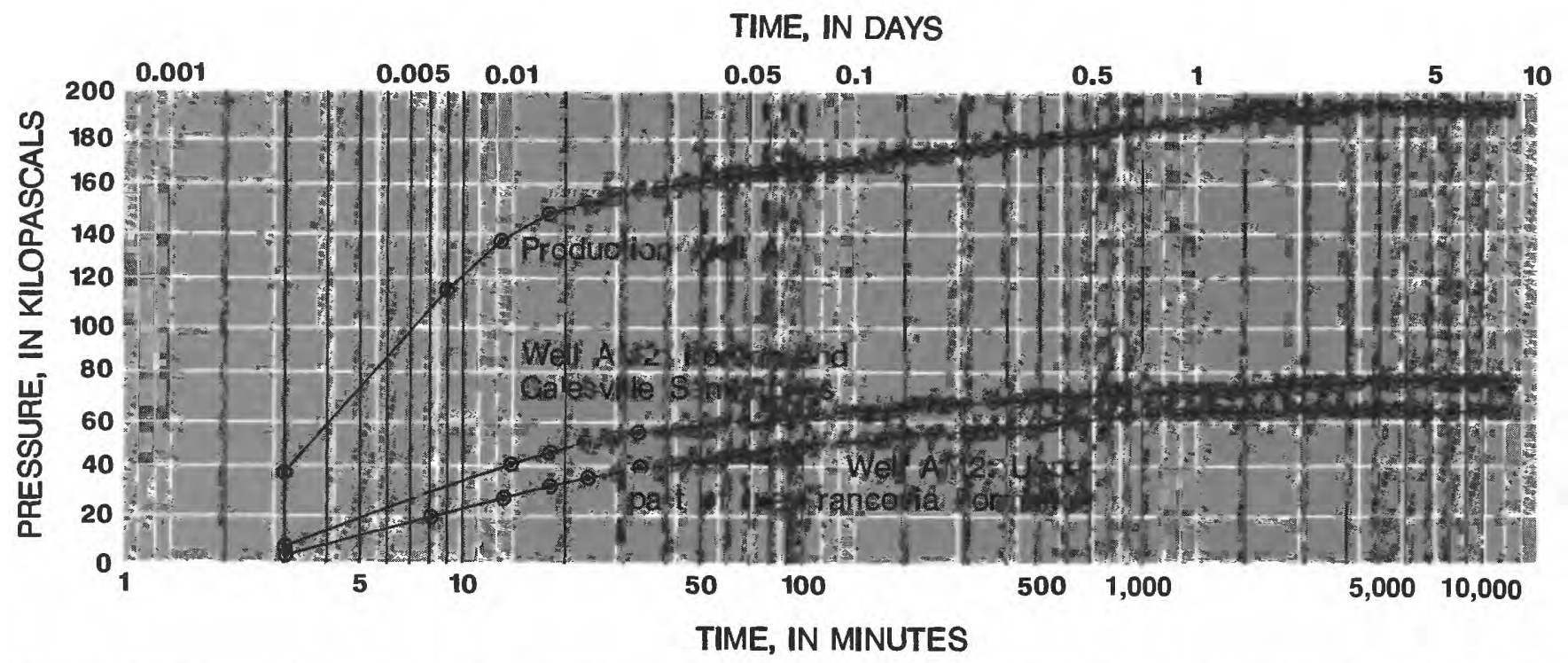

FigURE 17. - Pressure changes for injection at 18.6 liters per second at observation well AM2 in the upper part of the Franconia Formation and in the Ironton and Galesville Sandstones and in production well A.

potential for air entrainment and subsequent clogging. Figure 17 shows the pressure changes in production well A and in observation well AM2 for the upper part of the Franconia Formation and for the Ironton and Galesville Sandstones for 8 days of injection at $18.6 \mathrm{~L} / \mathrm{s}$. Most of the pressure build up in production well A occurred within the first day of injection. The rate of pressure change in well $\mathrm{A}$ and in the observation well was extremely low after 2 days of injection, which suggests that the aquifer approaches steady state quickly during injection. Figure 17 also indicates that redevelopment of production well $\mathrm{A}$ was successful and that aquifer characteristics near the well bore were not seriously changed by air-entrainment clogging. It is likely that not all the injected air was removed from the aquifer during redevelopment and that values of hydraulic conductivity were lowered slightly near the well bore. However, interpretation of data from hot-water-injection testing should not be significantly affected.

\section{PRELIMINARY MODELING ANALYSIS}

Two models were constructed to analyze ground-water flow and thermal-energy transport. Early in the study, a preliminary two-dimensional, radial-flow, isotropic, nonisothermal, ground-water-flow and thermal-energytransport model was constructed from available data. This model was used (1) for short-term sensitivity analyses of selected hydrogeologic and thermal characteristics of the aquifer, (2) to determine the potential for buoyancy-flow effects, (3) to develop a method to exam- ine the efficiency of the aquifer for heat storage, and (4) to demonstrate how changes in cyclic injection and withdrawal rates and duration can affect aquifer efficiencies and production well temperatures.

The second model was a three-dimensional anisotropic, nonisothermal ground-water-flow and thermal-energytransport model. This model was developed to more accurately represent field conditions and to simulate the doublet-well system and the short-term heat-injection testing. Both models use the same computer code.

\section{CONCEPTUAL MODEL}

A conceptual model of ground-water movement was developed from the field observations previously described and from water-level measurements in the Franconia-Ironton-Galesville aquifer and in the confining units of the St. Lawrence and Eau Claire Formations. Figure 18 illustrates water levels from piezometers completed in the St. Lawrence and Eau Claire Formations confining units, the upper and lower parts of the Franconia Formation, and the Ironton and Galesville Sandstones for monitoring wells AM1 and AM2 (see figs. 3 and 12 for depth and location). The predominant hydraulic-head gradient is downward because hydraulic heads decrease with depth beneath the site.

Horizontal flow in the upper part of the Franconia Formation differs from horizontal flow in the Ironton and Galesville Sandstones. Because of its relatively low hydraulic conductivity, the lower part of the Franconia Formation acts as a confining layer for water in the Ironton and Galesville Sandstones. Water levels at sites 


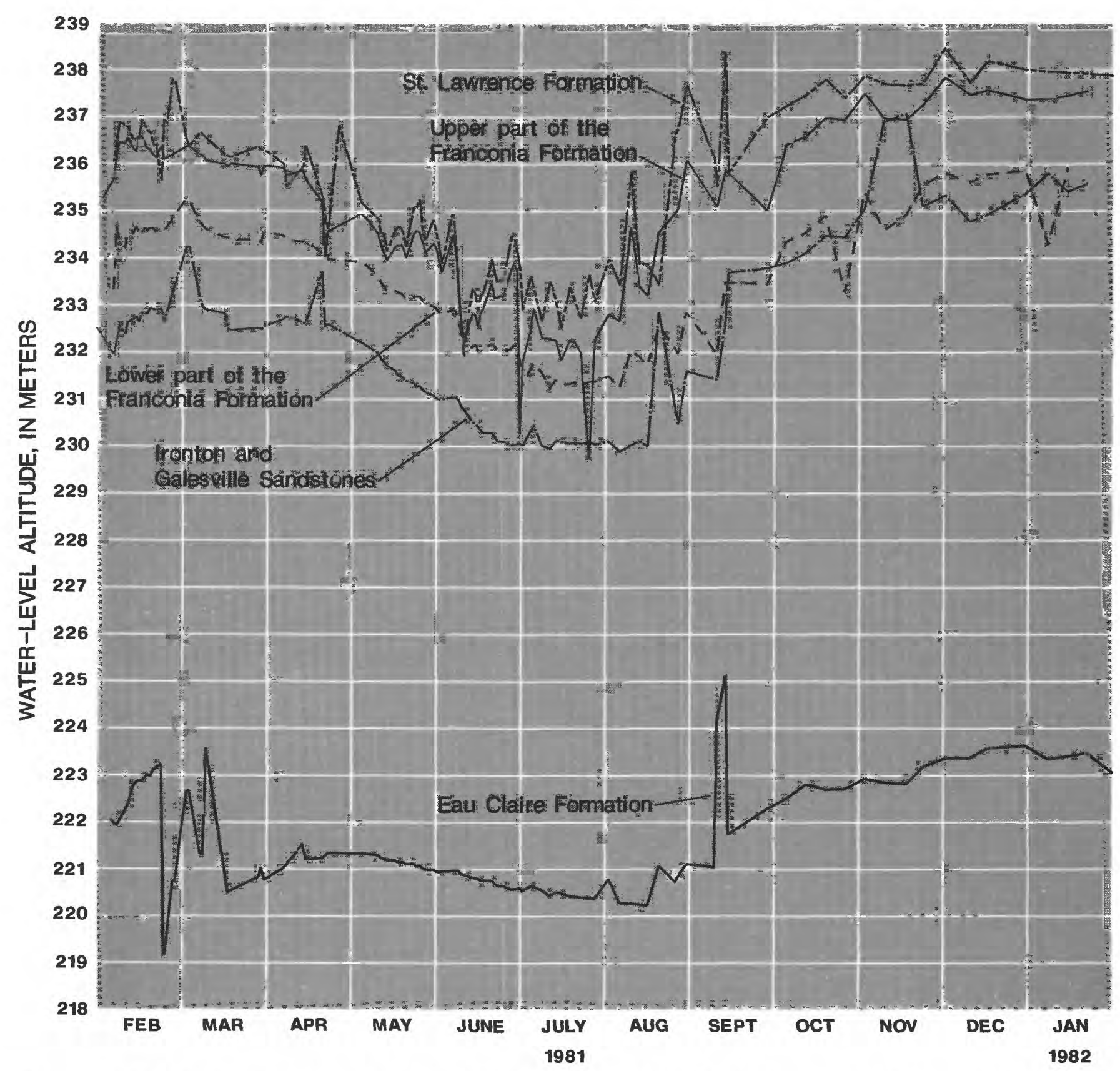

FIGURE 18. - Water-level measurements from February 1981 through January 1982 for the St. Lawrence, Franconia, and Eau Claire Formations and Ironton and Galesville Sandstones.

$\mathrm{A}, \mathrm{B}$, and $\mathrm{C}$ indicate a gradient of $2.6 \times 10^{-3}$ for the upper part of the Franconia Formation and a gradient of $7.0 \times 10^{-4}$ for the Ironton and Galesville Sandstones. The direction of horizontal ground-water flow is from site $\mathrm{C}$ toward site B.

Average linear water velocities in the upper part of the Franconia Formation and in the Ironton and Galesville Sandstones were determined from the equation (Freeze and Cherry, 1979)

$$
V=\frac{K \Delta h}{\phi \Delta l}
$$

where

$V=$ the average linear velocity $[l / t](\mathrm{m} / \mathrm{yr})$,

$K=$ horizontal hydraulic conductivity $[l / t](\mathrm{m} / \mathrm{d})$,

$\frac{\Delta h}{\Delta l}=$ hydraulic gradient $[l / l](\mathrm{m} / \mathrm{m})$, and $\phi=$ porosity [dimensionless]. 


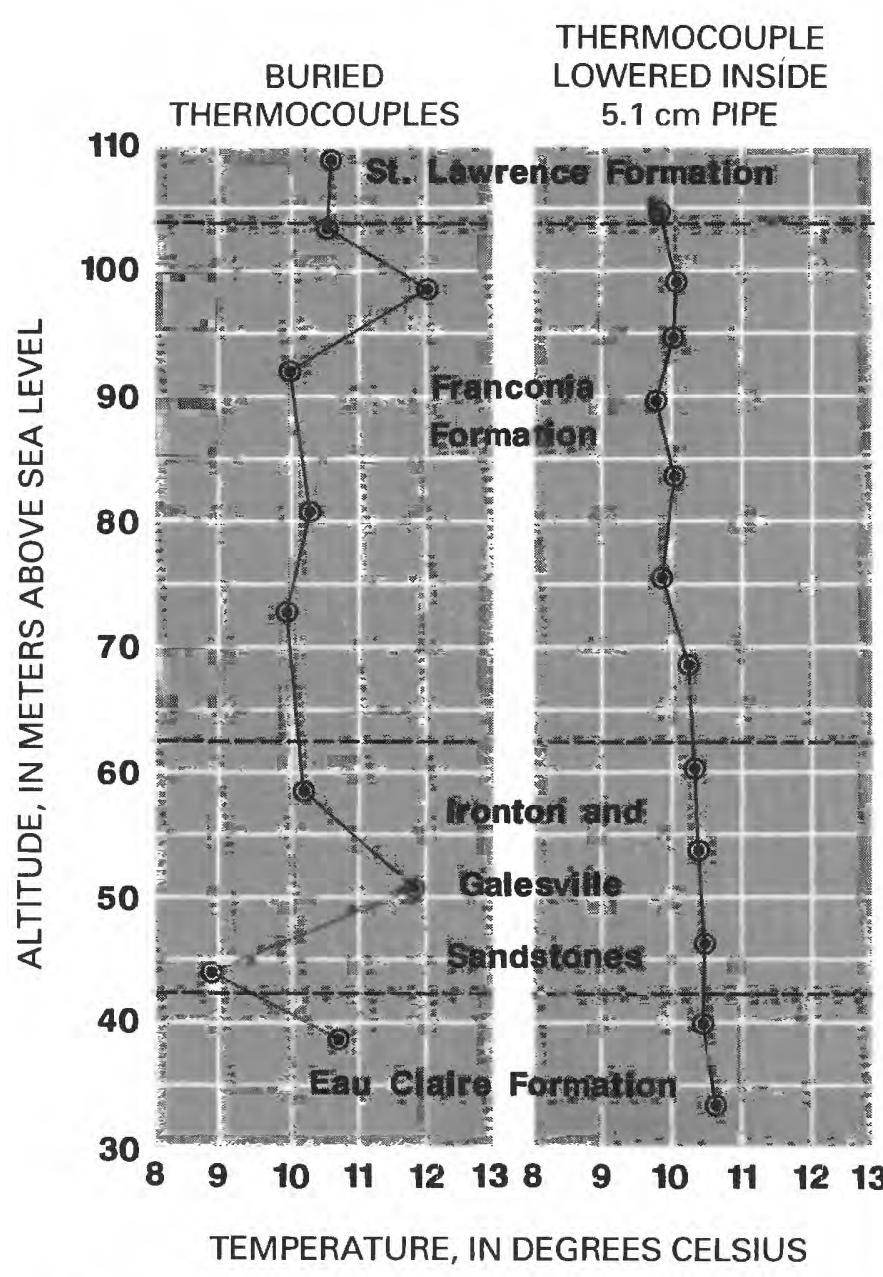

FIGURE 19, - Temperature profile for observation well AM1.

The average values of horizontal hydraulic conductivity determined from the transmissivities in table 8, a porosity of 25 percent and the hydraulic gradient determined from observation well measurements (fig. 18), were used in this equation. The results show the average linear velocity of water in the upper part of the Franconia Formation is $2 \times 10^{2}$ meters per year $(\mathrm{m} / \mathrm{yr})$; and the velocity in the Ironton and Galesville Sandstones is $1.3 \times 10^{2} \mathrm{~m} / \mathrm{yr}$.

The thermal gradient increases with depth at a rate of approximately $0.5^{\circ} \mathrm{C}$ per $30 \mathrm{~m}$. Figure 19 illustrates a temperature profile for observation well AM1 for the St. Lawrence Formation through the Eau Claire Formation for a thermocouple lowered inside a 5.2-cm-diameter pipe and for thermocouples buried outside the pipe. The variations in temperature at altitudes of approximately 100,51 , and $45 \mathrm{~m}$ are due to individual broken cables in the buried thermocouples.

\section{DESCRIPTION OF NUMERICAL MODELING}

The finite-difference ground-water-flow and thermalenergy-transport model used in this study was developed for waste-injection problems (Intercomp, 1976) and is referred to here as the Survey Waste Injection Program (SWIP) code. The SWIP code considers ground-water flow and heat, and solute transport in a liquid-saturated porous medium; it contains both reservoir and well-bore modeling capabilities.

The major model assumptions include the following (Intercomp, 1976):

1. Three-dimensional, transient, laminar (Darcy) flow.

2. Fluid density as a function of pressure, temperature, and concentration.

3. Fluid viscosity as a function of temperature and concentration.

4. The injected fluid is miscible with the in-place fluids.

5. Aquifer properties vary with location.

6. Hydrodynamic dispersion is described as a function of fluid velocity.

7. The energy equation can be described as enthalpy in minus enthalpy out equals the change in internal energy of the system.

8. Boundary conditions allow natural water movement in the aquifer, heat losses to the adjacent formation, and the location of injection, withdrawal, and observation points anywhere within the system.

9. Thermal equilibrium exists within the simulation area.

\section{MODEL EQUATIONS}

The basic equation describing single-phase flow in a porous medium results from a combination of the continuity equation and Darcy's law in three dimensions and results in the basic flow equation (Intercomp, 1976, p. 3.4)

$$
\nabla \times\left(\frac{\rho k}{\mu}(\nabla p-\rho g \nabla z)\right)-q^{\prime}=\frac{\partial}{\partial t}(\phi \rho)
$$

where

$\rho=$ fluid density $\left[\mathrm{m} / \mathrm{l}^{3}\right]\left(\mathrm{kg} / \mathrm{m}^{3}\right)$,

$\mu=$ fluid viscosity $[\mathrm{m} / \mathrm{l}-\mathrm{t}]$ (Pa-s),

$k=$ intrinsic permeability $\left[l^{2}\right]\left(\mathrm{m}^{2}\right)$,

$g=$ gravitational acceleration $\left[l / t^{2}\right]\left(\mathrm{m} / \mathrm{s}^{2}\right)$,

$z=$ spatial dimension in direction of gravity $[l]$ $(\mathrm{m})$,

$p=$ pressure $\left[\mathrm{m} / \mathrm{l}-\mathrm{t}^{2}\right](\mathrm{Pa})$,

$q^{\prime}=$ mass rate of flow per unit volume from sources or sinks $\left[\mathrm{m} / \mathrm{t}-\mathrm{l}^{3}\right]\left(\mathrm{kg} / \mathrm{s}-\mathrm{m}^{3}\right)$,

$t=$ time $[t]$ (s),

$\phi=$ porosity [dimensionless], and

$\nabla=$ gradient operator (for an axially symmetric 

cylindrical coordinate system $\nabla$ is: $\left(\frac{1}{r}\right)\left(\frac{\partial}{\partial r}\right)+$
$\left(\frac{\partial}{\partial z}\right)$ where $r$ is the radial dimension).

This equation may be combined with an energy balance (defined as enthalpy in minus enthalpy out equals change in internal energy) to describe the transport of thermal energy in a ground-water system, as (Intercomp, 1976, p. 3.4)

$$
\begin{aligned}
& \nabla \times\left(\frac{\rho k}{\mu} H(\nabla p-\rho g \nabla z)\right)+\nabla \times K \times \nabla T-q_{L}-q^{\prime} H= \\
& \frac{\partial}{\partial t}\left(\phi \rho U+(1-\phi)\left(\rho C_{p}\right)_{R} T\right)
\end{aligned}
$$

where

$H=$ enthalpy per unit mass of fluid $[E / m](\mathrm{J} / \mathrm{kg})$,

$K=$ hydrodynamic thermal dispersion plus convection $[E / t / l-T]\left(\mathrm{W} / \mathrm{m}-{ }^{\circ} \mathrm{C}\right)$,

$T=$ temperature $[T]\left({ }^{\circ} \mathrm{C}\right)$,

$q_{L}=$ heat loss across boundaries $\left[E / t / l^{3}\right]\left(\mathrm{W} / \mathrm{m}^{3}\right)$,

$U=$ internal energy per unit mass of fluid $[E / m]$ $(\mathrm{J} / \mathrm{kg})$,

$\left(\rho C_{\mathrm{p}}\right)_{\mathrm{R}}=$ heat capacity of the aquifer matrix $\left[E / l^{3}-T\right]$ $\left(\mathrm{J} / \mathrm{m}^{3}-^{\circ} \mathrm{C}\right)$, and

$C_{p}=$ specific heat of aquifer matrix $[E / m-T](\mathrm{J} / \mathrm{kg}-$ ${ }^{\circ} \mathrm{C}$ )

and all other terms are previously defined.

Equation 17 is a nonlinear system of coupled partialdifferential equations that are solved numerically by subdividing the aquifer into discrete blocks in three dimensions (or two dimensions for radial flow) and developing finite-difference approximations.

Finite-difference equations (Intercomp, 1976, p. 3.4) whose solution closely approximates the solution of equations 16 and 17 are, for the basic flow equation

$$
\Delta\left(T_{W}(\Delta p-\rho g \Delta z)\right)-q=\frac{V}{\Delta t} \delta(\phi \rho)
$$

and for the energy equation

$\Delta\left(T_{W} H(\Delta p-\rho g \Delta z)\right)+\Delta\left(T_{C} \Delta T\right)-q_{L}-q^{\prime} H=\frac{V}{\Delta t} \delta\left(\begin{array}{l}\phi \rho U+(1- \\ \phi)\left(\rho C_{p}\right)_{R} T\end{array}\right)$

where

$$
\text { and } \quad \begin{aligned}
\delta \chi & =\chi^{n+1}-\chi^{n} \\
T_{W} & =\frac{K A \rho}{\mu l} \\
T_{C} & =\frac{K A}{l}
\end{aligned}
$$

where

$A=$ area perpendicular to flow (that is, $\Delta x \Delta y$, $\Delta x \Delta z$, or $\Delta y \Delta z)$, and

$l=$ distance between grid block centers and all other terms are as previously defined.

The finite-difference operators are defined as

$$
\Delta\left(T_{w} \Delta p\right)=\Delta_{x}\left(T_{w} \Delta_{x} p\right)+\Delta_{y}\left(T_{w} \Delta_{y} p\right)+\Delta_{z}\left(T_{w} \Delta_{z} p\right)
$$

with the terms

$$
\begin{array}{r}
\Delta_{x}\left(T_{W} \Delta_{x} p\right)=T_{W, i+0.5, j, k}\left(p_{i+1, j, k}^{n+1}-p_{i, j, k}^{n+1}\right) \\
T_{W, i-0.5, j, k}\left(p_{i, j, k}^{n+1}-p_{i-1, j, k}^{n+1}\right)
\end{array}
$$

where the subscripts $x, y, z=$ the cartesian space coordinates,

$$
\begin{gathered}
i, j, k=\text { grid block indices, } \\
n=\text { time level, } t_{n}
\end{gathered}
$$

and all other terms as previously defined.

Finally, the thermal-conductance term, $K$, in equation 21 may be further defined as (Intercomp, 1976, p. 3.7)

$$
\left.K=\phi\left(\frac{\alpha u}{\phi}\right) \rho C_{p}\right)_{w}+K_{m}
$$

where

$$
\begin{aligned}
\alpha= & \text { the thermal dispersivity }[l](\mathrm{m}), \\
\phi= & \text { porosity [dimensionless }] \\
u= & \text { volumetric flux (Darcy velocity) }[l / t](\mathrm{m} / \mathrm{s}), \\
\left(\rho C_{p}\right)_{w}= & \text { heat capacity of water }\left[E / l^{3}-t\right]\left(\mathrm{J} / \mathrm{m}^{3}-{ }^{\circ} \mathrm{C}\right), \text { and } \\
K_{m}= & \text { molecular heat conductivity of porous media } \\
& {[E / t-l-t]\left(\mathrm{W} / \mathrm{m}-{ }^{\circ} \mathrm{C}\right) . }
\end{aligned}
$$

\section{DESCRIPTION OF RADIAL-FLOW MODEL}

As described earlier, the ATES system consisted of a doublet-well system. The steady-state flow field for a doublet-well system with well spacing equal to that of the ATES system $(250 \mathrm{~m})$ is shown in figure 20 . The equipotentials indicate that the preliminary model assumption of radial flow was less exact with increasing distance from the center of either well bore. For the preliminary model simulations described in this report, all the injected heat was maintained within the boxed area around the injection well shown in figure 20. Figure 20 also shows the location of the preliminary model boundary in relation to the doublet-well flow field.

Most of the injected heat, calculated by the preliminary model during sensitivity-analysis simulations, was concentrated within a radial distance of approximately $14 \mathrm{~m}$ from the injection well. None of the sensitivityanalysis simulations calculated movement of injected heat beyond approximately $17 \mathrm{~m}$. The $17-\mathrm{m}$ and $14-\mathrm{m}$ 


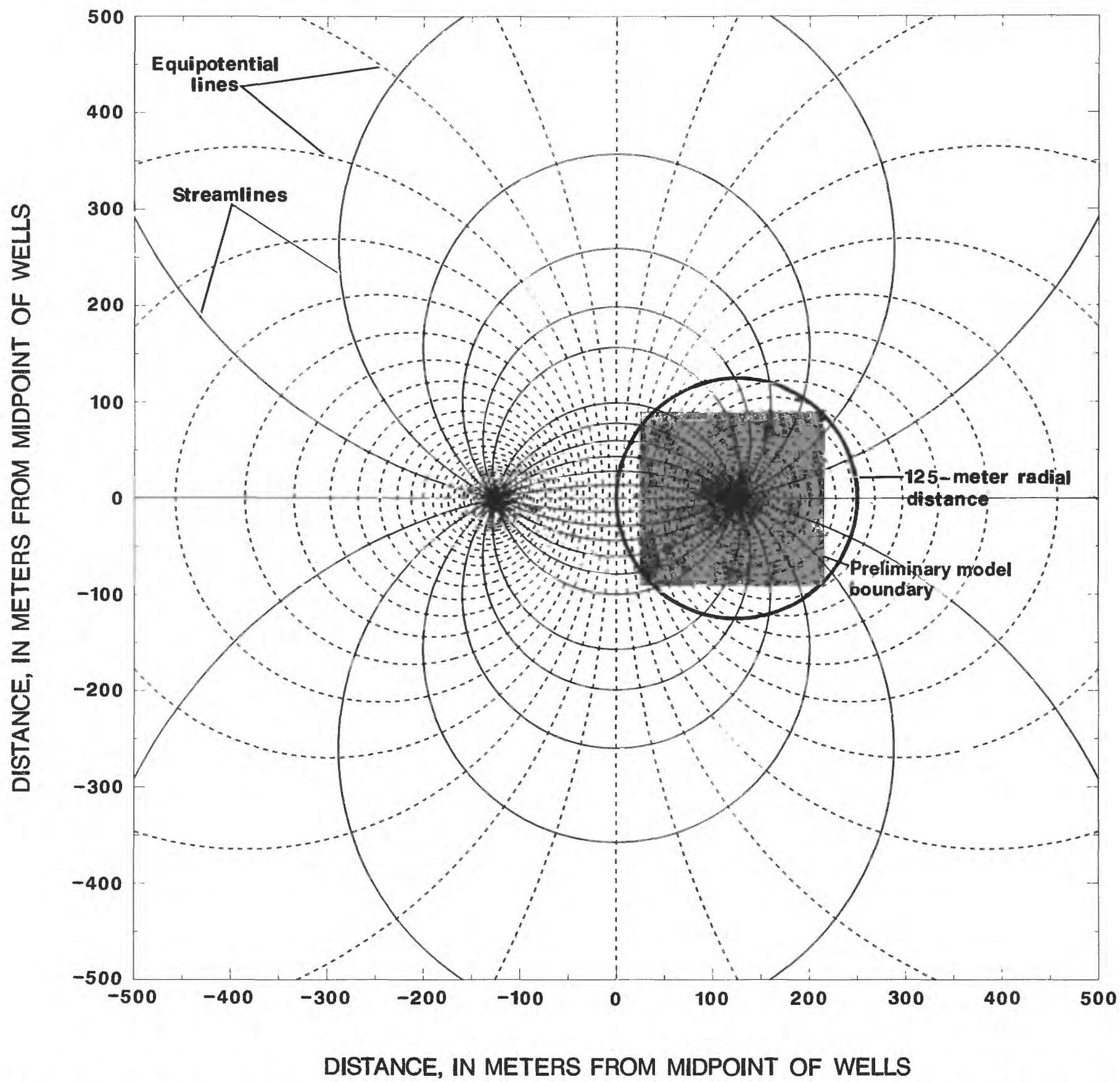

FIGURE 20.-Flow net showing a doublet-well system similar to the Aquifer Thermal-Energy Storage system and the preliminary model boundary.

radial distances from the well are shown in figure 21 , which is an enlargement of the box area shown in figure 20. Comparison of the equipotentials for the doublet-well system and the 17-m model-computed radial extent of heat indicates that the preliminary model radial-flow assumption was fairly accurate for the sensitivityanalysis simulations. However, as indicated in the discussion of buoyancy flow, the sensitivity of certain properties may change with longer-term cycles (greater than 60 days).

\section{SENSITIVITY ANALYSIS}

\section{APPROACH}

Sensitivity analyses were performed on the preliminary model for the hydraulic properties of hydraulic 


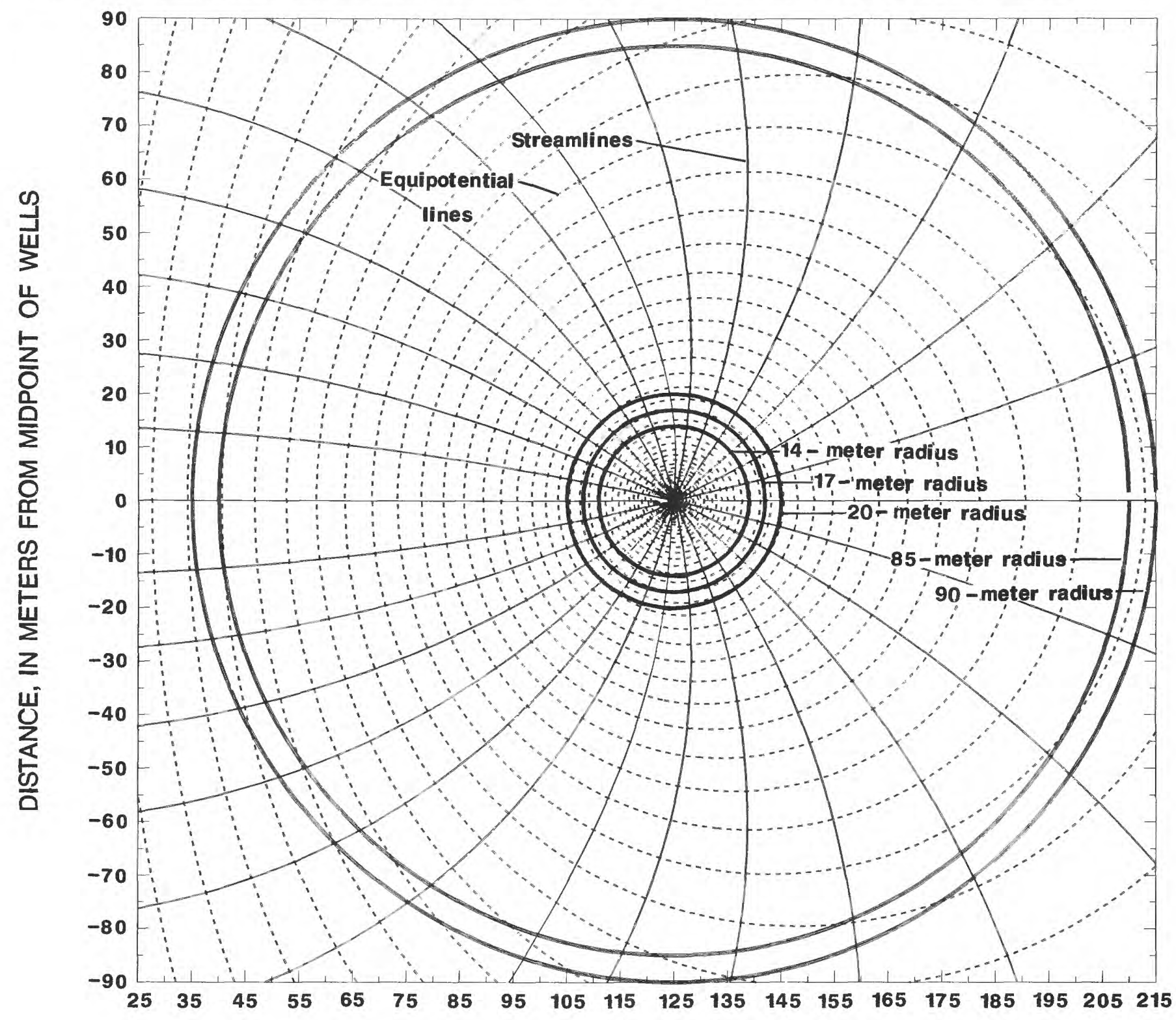

\section{DISTANCE, IN METERS FROM MIDPOINT OF WELLS}

FiguRE 21. - Flow net within the preliminary model boundary for a doublet-well system similar to the Aquifer Thermal-Energy Storage system. (From Miller and Voss, 1986.)

conductivity, porosity, and vertical anisotropy, and on the thermal properties of rock-thermal conductivity, rock-heat capacity, and thermal dispersivity. A radialflow base model was constructed with data from borehole-geophysical logs, analysis of core samples, inflatable-packer tests, previous studies, and laboratory values reported in text books. Base-model-hydraulic and thermal characteristics are presented in tables 9 and 10 , respectively.

The purpose of the sensitivity analysis was to determine the relative importance of individual hydraulic and thermal characteristics in the computation of temperatures and aquifer-thermal efficiency in relation to the preliminary radial-flow model. This information was used to guide data collection and to adjust model-input properties during calibration of subsequent models which used data from the 24-day test cycles. Therefore, the simulation used in sensitivity analysis consisted of 8 days of injection of $150^{\circ} \mathrm{C}$ water at a rate of $18.9 \mathrm{~L} / \mathrm{s}$, 8 days of storage, and 8 days of withdrawal at a rate of $18.9 \mathrm{~L} / \mathrm{s}$. 


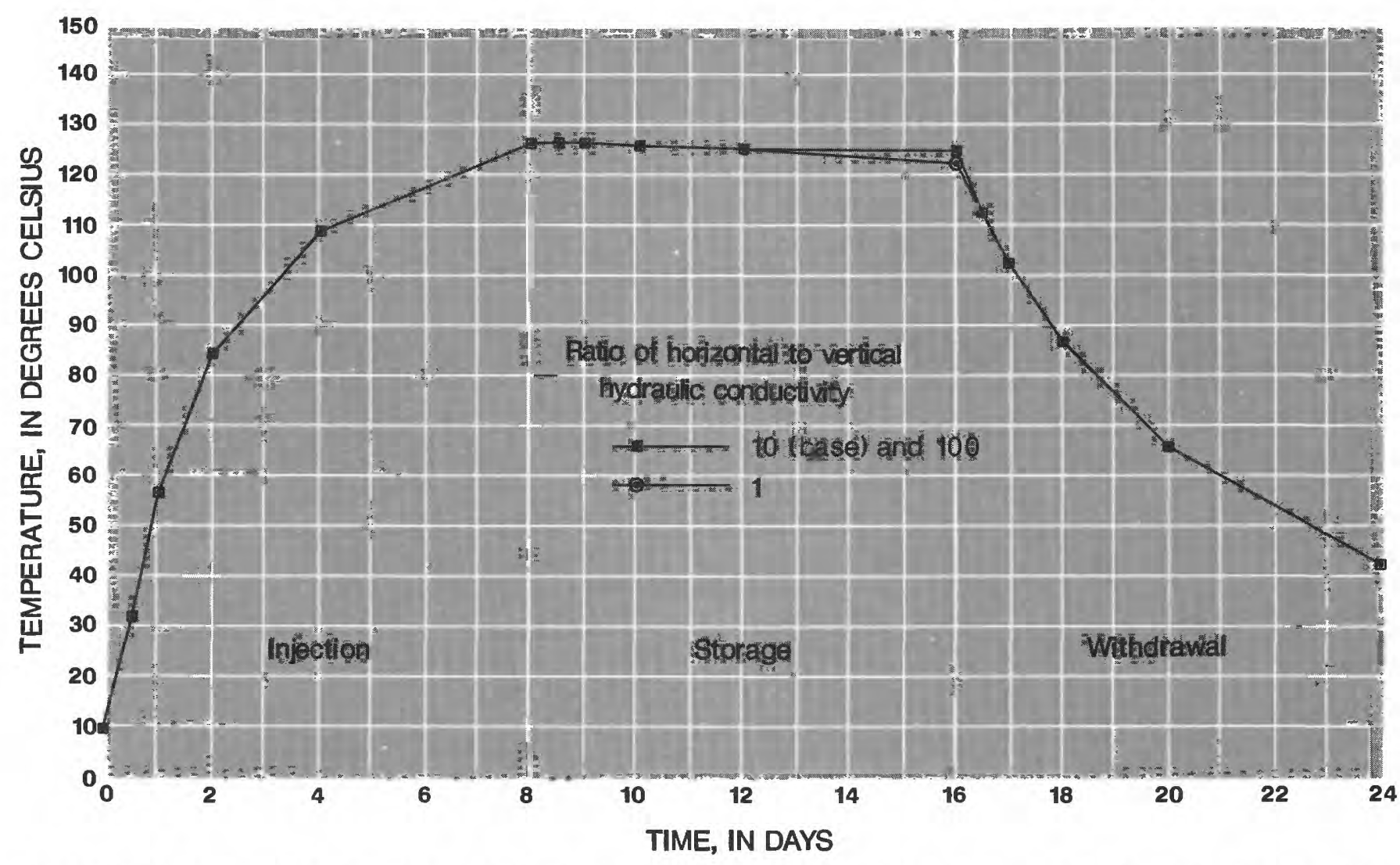

FigURE 22. - Model-computed temperatures for different values of horizontal to vertical hydraulic conductivity. (From Miller and Voss, 1986.)

TABLE 9.-Hydraulic zonation, thickness, and horizontal hydraulic conductivity determined from borehole geophysical logs, core samples, and inflatable packer-test data

\begin{tabular}{lcc}
\hline Horizontal zone & $\begin{array}{c}\text { Thickness } \\
\text { (meters) }\end{array}$ & $\begin{array}{c}\text { Horizontal } \\
\text { hydraulic } \\
\text { conductivity } \\
\text { (meters per day) }\end{array}$ \\
\hline $\begin{array}{l}\text { Upper part of the Franconia } \\
\quad \text { Formation }\end{array}$ & 13.7 & 0.6 \\
$\begin{array}{l}\text { Lower part of the Franconia } \\
\quad \text { Formation }\end{array}$ & 24.4 & .03 \\
$\begin{array}{l}\text { Ironton Sandstone } \\
\text { Galesville Sandstone }\end{array}$ & 15.2 & 1.2 \\
\hline
\end{tabular}

To determine the relative sensitivity of the model to different values of selected properties, temperature versus time plots were constructed from model results and compared with similar plots for the base-model simulation. The temperatures represent a point within the Ironton and Galesville Sandstones at a radial distance of approximately $6.5 \mathrm{~m}$ from the injection well. Aquifer thermal efficiency was calculated as a percentage by dividing the total heat produced during withdrawal by the total heat injected. The aquifer thermal efficiency of the base simulation is 51.0 percent. The following discus-
TABLE 10. - Summary of relevant system thermal properties

\begin{tabular}{lll}
\hline $\begin{array}{l}\text { Rock-thermal } \\
\text { conductivity (aquifer } \\
\text { and confining units) }\end{array}$ & $=2.20 \times 10^{-5}$ & $\begin{array}{l}\text { joules per meter per } \\
\text { day per degree } \\
\text { Celsius }\end{array}$ \\
$\begin{array}{ll}\text { Thermal dispersivity } \\
\text { Rock-heat capacity }\end{array}$ & $=3.81 \times 10^{6}$ & $\begin{array}{l}\text { meters } \\
\text { joules per cubic meter } \\
\text { per degree Celsius }\end{array}$ \\
\hline
\end{tabular}

sion of individual properties is ordered from least to most sensitive in the model simulation.

\section{HYDRAULIC AND THERMAL PROPERTIES}

Ratio of Horizontal to Vertical Hydraulic Conductivity

In the radial-flow model, horizontal hydraulic conductivity $\left(K_{H}\right)$ was equal in all horizontal directions. Therefore, the only anisotropy that could be simulated was the ratio of the horizontal to vertical hydraulic conductivity $\left(K_{H} / K_{V}\right)$.

The ratio of $K_{H}$ to $K_{V}$ was varied from an isotropic condition $\left(K_{H} / K_{V}=1\right)$ to $K_{H} / K_{V}$ equal to 100 . The base value of $K_{H} / K_{V}$ is assumed to be 10 (Norvitch and others, 1973). Figure 22 shows that simulation of different values of $K_{H} / K_{V}$ had negligible effect on model-computed temperatures. The calculated aquifer efficiencies were 


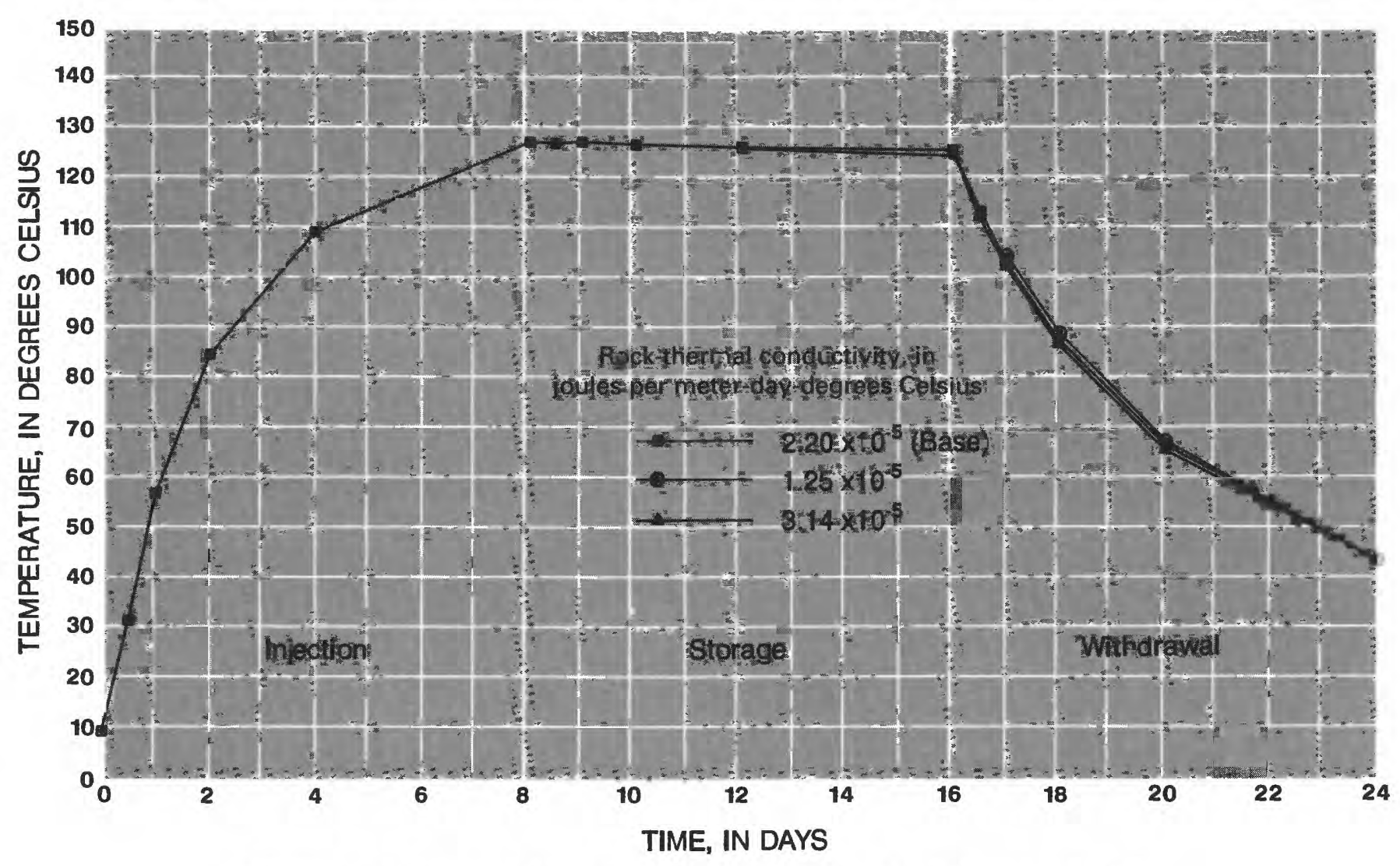

FiguRE 23.-Model-computed temperatures for different values of rock-thermal conductivity.

50.7 percent for $K_{H} / K_{V}$ equal to 1 , and 50.9 percent for $K_{H} / K_{V}$ equal to 100 . Insensitivity of the model to the ratio of $K_{H} / K_{V}$ probably was due to the relatively low values of hydraulic conductivity. The ratio of $K_{H}$ to $K_{V}$ will be shown to be more important in the simulation of heat convection at the thermal front because of density differences between the warm injection water and the cooler ground water. The relation between the ratio of $K_{H}$ to $K_{V}$ and water-density differences is described in the section on buoyancy flow.

Rock-Thermal Conductivity

Values of rock-thermal conductivity were varied in the model according to approximate values given in Clark (1966) for sandstones comparable in composition to those in the Franconia-Ironton-Galesville aquifer. The reduction of rock-thermal conductivity with increase in temperature, as reported by Birch and Clark (1940), Somerton and others (1965), and Clark (1966), is not accounted for in the SWIP code. This difference probably did not present problems because the reduction of rock-thermal conductivity described by these authors is small for the injection temperature $\left(150^{\circ} \mathrm{C}\right)$ and is within the range described for sandstone aquifers (Clark, 1966) and used in the sensitivity analysis. Figure 23 shows the computed temperatures for different values of rock-thermal conductivity. The plots indicate a small divergence in the computed temperatures during storage, which is reflected in computed aquifer thermal efficiencies of 51.8 and 50.3 percent for the rock-thermal conductivities of $1.25 \times 10^{-5}$ and $3.14 \times 10^{-5} \mathrm{~J} /\left(\mathrm{m}-\mathrm{d}-{ }^{\circ} \mathrm{C}\right)$, respectively. This divergence in temperature probably is due to the effects of the rock-thermal conductivity, which are small during injection in comparison to the effects of heat convection in the moving ground water. Therefore, the simulated effects of thermal conductivity are not observed until the storage period and then remain constant through withdrawal.

\section{Horizontal Hydraulic Conductivity}

Values of horizontal hydraulic conductivity (fig. 24) an order of magnitude greater than and less than the assumed base value (table 9 ) were simulated in the model with the base ratio of $K_{H} / K_{V}$ equal to 10 . The lesser value resulted in computed temperatures and an aquifer thermal efficiency that differed only slightly from the base simulation. The greater value of hydraulic conductivity resulted in lower computed temperatures during storage and a calculated aquifer thermal efficiency of 49.5 percent (base value equals 51.0 percent). This difference 


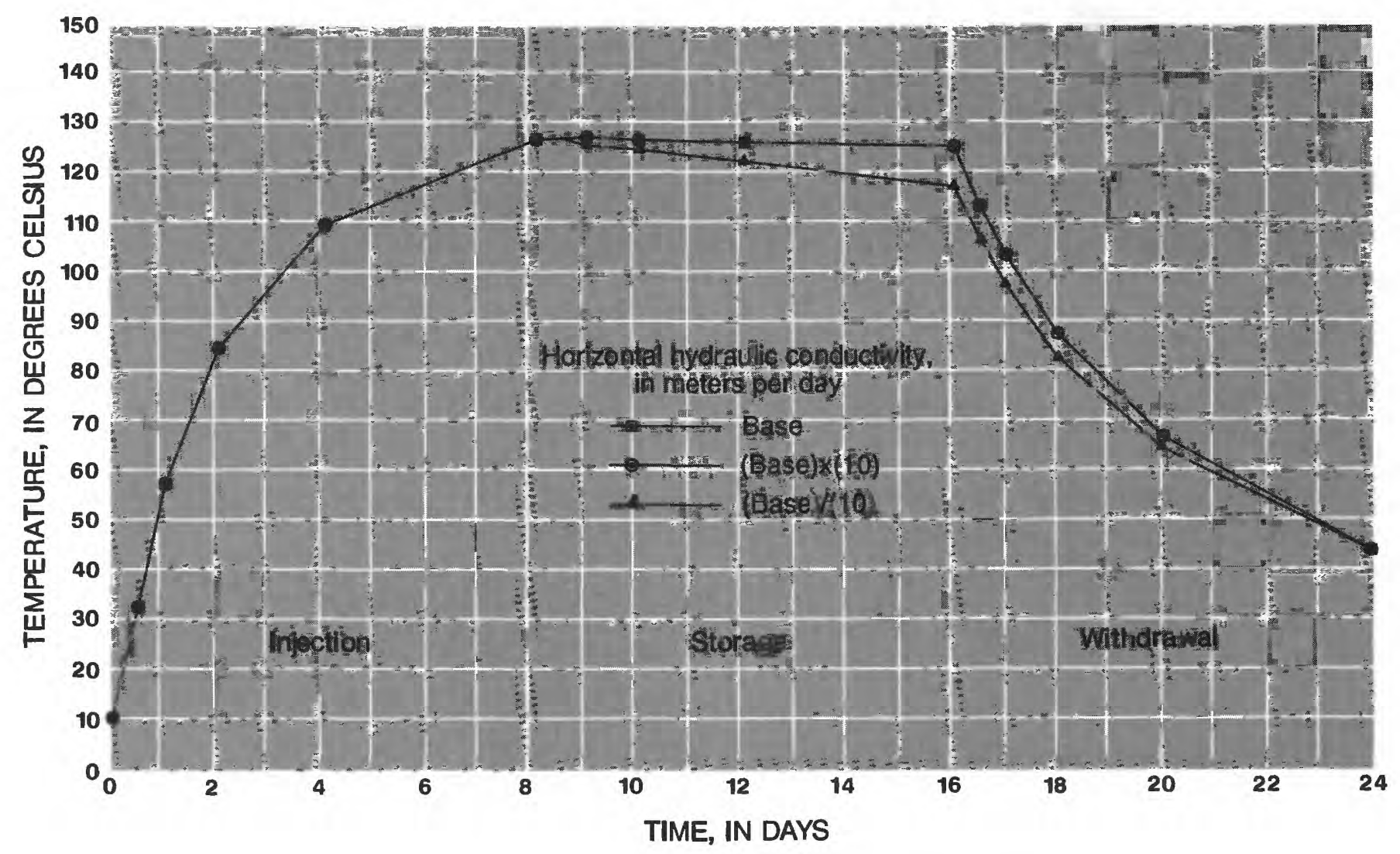

\section{EXPLANATION}

Horizontal Hydraulic Conductivity

[in meters per day]

\begin{tabular}{lccc}
\hline \multicolumn{1}{c}{ Formation } & Base & $($ Base $) \times(10)$ & $($ Base $) /(10)$ \\
\hline Upper part of the Franconia Formation & 0.6 & 6 & 0.06 \\
Lower part of the Franconia Formation & .03 & .3 & .003 \\
Ironton Sandstone & 1.2 & 12. & .12 \\
Galesville Sandstone & .3 & 3 & .03 \\
\hline
\end{tabular}

FIGURE 24.-Model-computed temperatures for different values of horizontal hydraulic conductivity.

probably is due to vertical convection resulting from the temperature-induced density differences between the natural and injected ground water. This effect is discussed in more detail in the section on buoyancy flow. In brief, the density differences between the warmer injected water and the cooler water in the aquifer allows hot water to move to the top of the aquifer where heat can be lost to the upper confining layer or move laterally away from the production well.

\section{Porosity}

A range of porosity values was selected from published data (Clark, 1966; Norvitch and others, 1973); from the laboratory analysis of core samples; from natural 


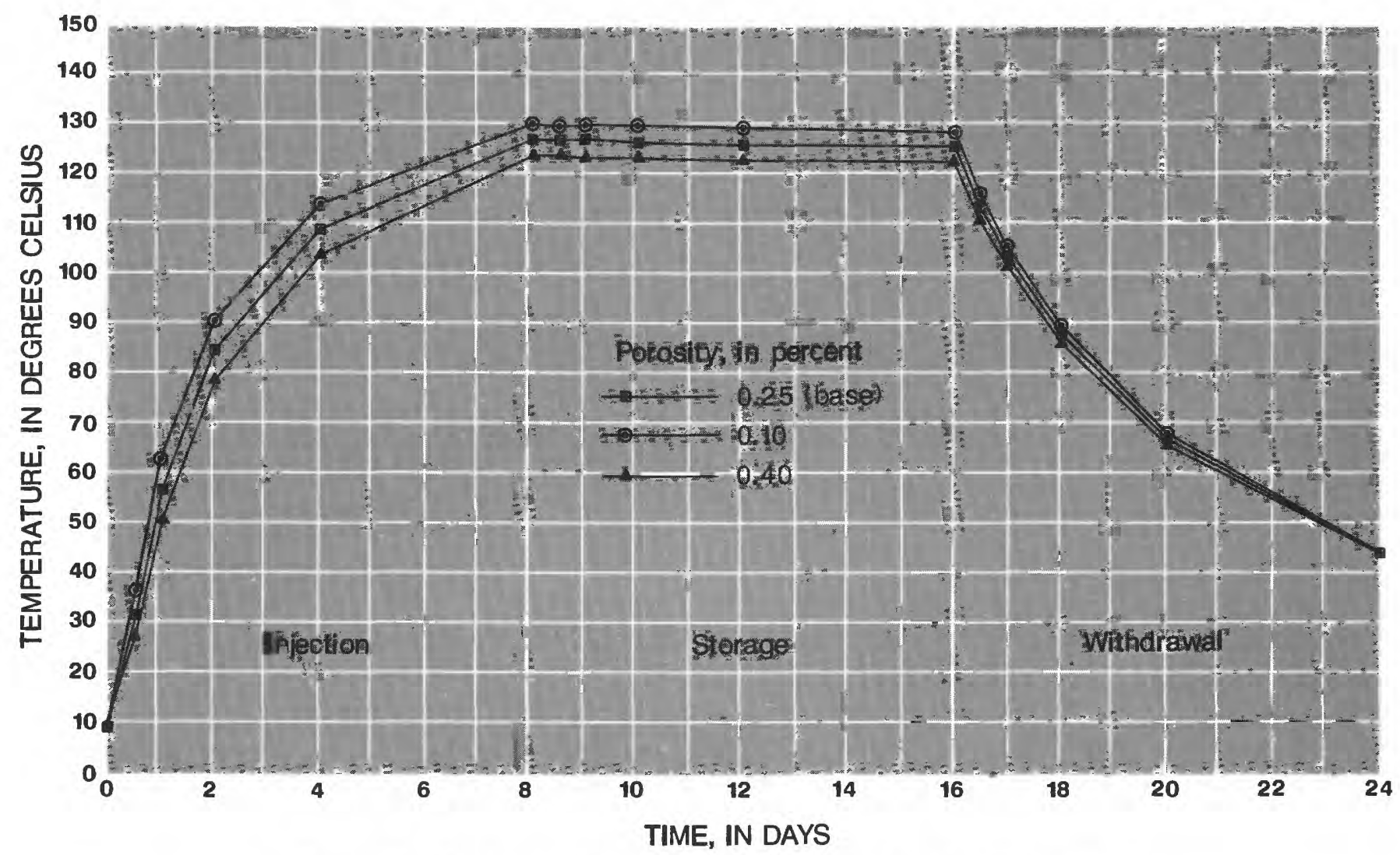

FIGURE 25.-Model-computed temperatures for different values of aquifer porosity.

gamma, gamma-gamma, and neutron borehole geophysical data; and from analyses of cores of the Franconia Formation and of the Ironton and Galesville Sandstones in southern Minnesota (Minnesota Gas Co., oral commun., 1980). The values ranged from 0.10 to 0.40 . The median value, 0.25 , was assumed to be the base value. Differences in model-calculated temperatures (fig. 25) for the value of porosity simulated were greatest during the injection period. These differences probably are due to the inverse proportionality of porosity to groundwater velocity. During injection and withdrawal, convection of heat by the moving ground water is the major mechanism of energy transport near the well where, for this analysis, the observation point is located. The greater the porosity, the slower the heat front will move and, thus, the lower the temperature calculated at the observation point. Model-calculated aquifer efficiencies for the porosities of 0.10 and 0.40 were 51.5 and 50.1 percent, respectively.

An increase in porosity also increases aquifer (water + rock) heat capacity. The greater the aquifer heat capacity, the more energy (heat) is required to raise an equal volume of aquifer $1^{\circ}$. This results in less heat, or a lower temperature, moving away from the well.

\section{Rock-Heat Capacity}

Rock-heat capacity is the product of rock density and rock specific heat and is a measure of the ability of the rock to store heat. Ranges of heat capacity were obtained from Somerton and others (1965) and calculated with data from Somerton and others (1965), Clark (1966), Helgeson and others (1978), and Robie and others (1978), and from methods described by Martin and Dew (1965). The base value for rock-heat capacity represents a sandstone with a composition similar to sandstones in the Franconia-Ironton-Galesville aquifer. The low value of rock-heat capacity represents a quartz-rich sandstone and the high value represents a clay-rich sandstone. The denser the rock, or the higher the specific heat, the greater the energy required to heat the rock. This is reflected in the model-computed temperatures in figure 26 for the different values of rock-heat capacity. Lower temperatures are calculated for higher values of rockheat capacity because of the energy required to heat the rock. Calculated aquifer thermal efficiencies for rockheat capacities of $1.00 \times 10^{6}$ and $2.68 \times 10^{6} \mathrm{~J} /\left(\mathrm{m}^{3}{ }^{\circ} \mathrm{C}\right)$ are 51.7 and 50.3 percent, respectively. 


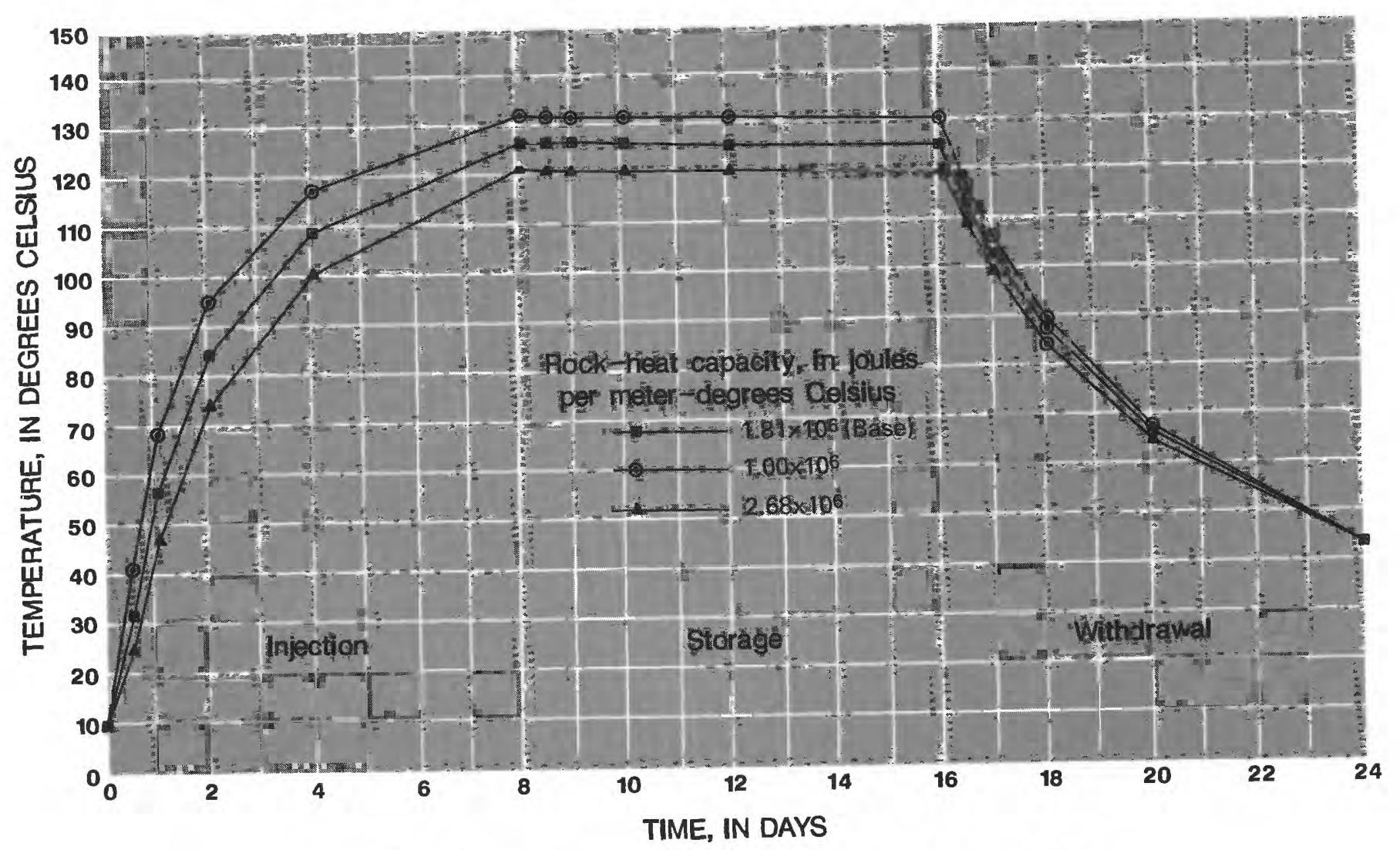

FIGURE 26. - Model-computed temperatures for different values of rock-heat capacity.

Thermal Dispersivity

The model was most sensitive to thermal dispersivity, which, unfortunately, is the most difficult property to measure in the ground-water-flow system. Although few data exist, Sauty and others (1978) conclude from heatinjection-tracer tests and model studies that thermal dispersivity probably is of the same order of magnitude as dispersivities measured by means of chemical tracers. Sauty and others (1978) also describe thermal dispersivity as a function of scale, suggesting a value of $0.1 \mathrm{~m}$ for a heat-storage radius of $10 \mathrm{~m}$ in isotropic aquifers. A base value of $3 \mathrm{~m}$ was assumed for sensitivity analysis.

In general, thermal dispersivity may be interpreted as dispersion of the thermal front; the length of the path a particle might take going from one point to another point in the aquifer is a function of the properties of the aquifer. The thermal front, defined for this report, is the transition zone between the warm injected water and the cooler water in the aquifer. Figure 27 shows a plan view of a hypothetical thermal front. It is important to note that the width of the thermal front can vary within the aquifer. When the particle path is more direct, the thermal dispersivity is smaller, the thermal front is thinner, and the heated water moves past a given point faster. When the path is longer, the dispersivity is

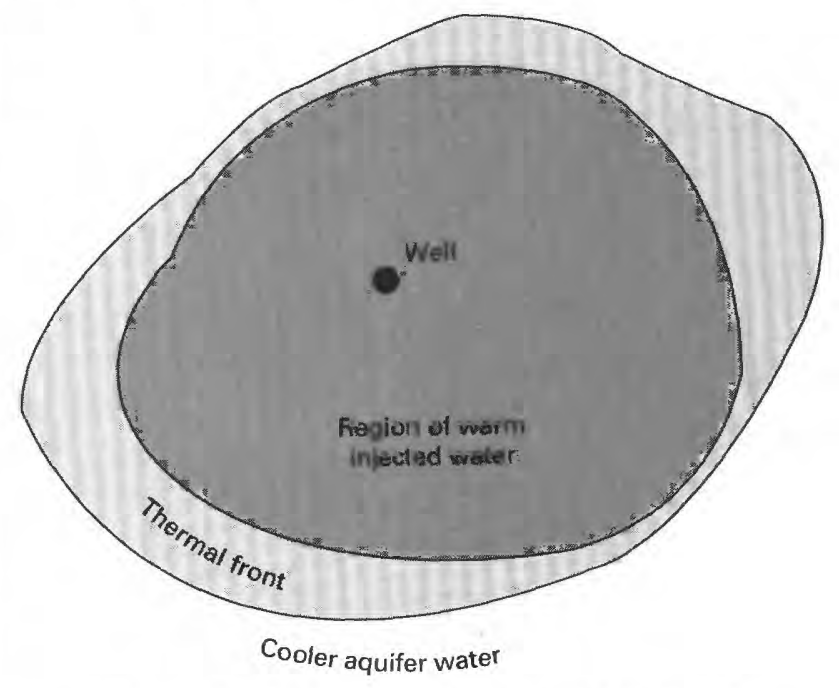

FIGURE 27.-Plan view of hypothetical heat front.

larger, the thermal front is wider, and the heated water moves past a given point slower. This variation is apparent in the very high temperature computed by the model early in the injection period. As shown in figure 28, a much higher temperature was computed for a thermal dispersivity of $0.0 \mathrm{~m}$ than was computed for a thermal dispersivity of $6.0 \mathrm{~m}$. 


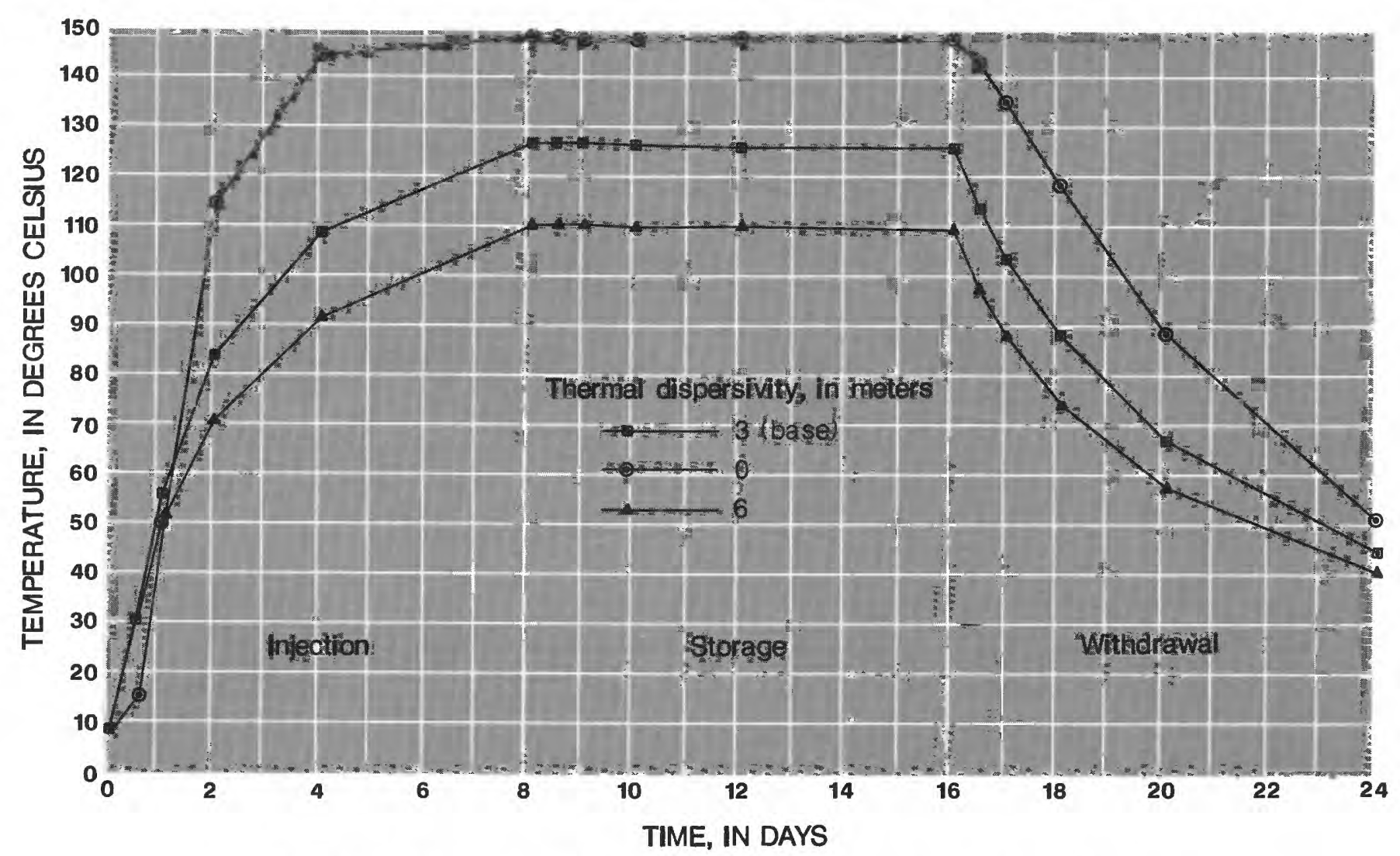

FIGURE 28. - Model-computed temperatures for different values of thermal dispersivity.

Of all the properties, thermal dispersivity has the greatest effect on the model-computed aquifer thermal efficiencies. A dispersivity of $0.0 \mathrm{~m}$ results in an efficiency of 66.8 percent, and a dispersivity of $6.0 \mathrm{~m}$ results in an efficiency of 43.4 percent.

\section{Buoyancy Flow}

Hellstrom and others (1979) describe the effects of thermal convection, called buoyancy flow, as the result of differences in density of the injected hot water and the cooler water in the aquifer. Their work was related to heat storage in shallow glacioalluvial aquifers, which generally have permeabilities higher than values reported for the Franconia-Ironton-Galesville aquifer. Figure 29 illustrates the effects of buoyancy flow. During early injection, the thermal front is approximately vertical. The thermal front is unstable because the hotter, lower-density water tends to rise convectively above the more dense cold water, resulting in thermal stratification in the aquifer and tilting of the thermal front. Heat losses from the aquifer to the confining units are roughly proportional to the areas of the upper and lower surfaces of the warm water region (fig. 29), (Hellstrom and others, 1979). Since buoyancy flow tends to increase this region, it also increases the potential for heat loss.

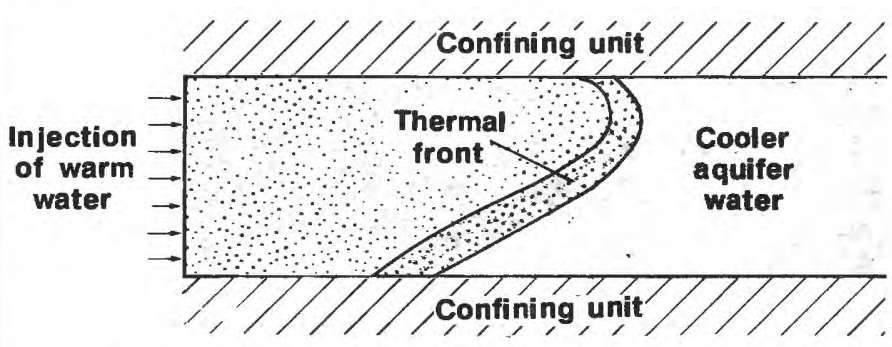

FigURE 29. - Horizontal injection of warm water in an aquifer with excessive thermal stratification illustrating tilting of the thermal front or buoyancy flow.

Excessive buoyancy flow may seriously reduce the efficiency of aquifer thermal storage.

To examine the potential for buoyancy flow and its possible effect on the thermal efficiency of the FranconiaIronton-Galesville aquifer, the nonisothermal, isotropic, single-phase, radial-ground-water-flow, thermal-energytransport model was used to simulate the 24-day test cycle. In this simulation temperature versus depth plots were constructed for selected values of horizontal hydraulic conductivity $\left(K_{H}\right)$ and the ratio $K_{H} / K_{V}$. As in previous simulations, the observation point for modelcomputed temperatures was $6.5 \mathrm{~m}$ radially from the injection well. The 24-day test cycle was simulated in the 


\begin{tabular}{lll}
\hline \multicolumn{1}{c}{ Property } & & Assumed base condition \\
\hline Ratio of horizontal to vertical hydraulic conductivity & 10 & \\
Rock thermal conductivity & $2.2 \times 10^{-5}$ & joules per meter per day per degree Celsius \\
Thermal dispersivity & 3 & meters \\
$\begin{array}{l}\text { Rock-heat capacity } \\
\text { Porosity }\end{array}$ & $1.18 \times 10^{6}$ & joules per cubic meter per degree Celsius \\
Horizontal hydraulic conductivity & 0.25 & \\
$\quad$ Upper part of the Franconia Formation & 0.6 & meters per day \\
$\quad$ Lower part of the Franconia Formation & 0.03 & meters per day \\
$\quad$ Ironton Sandstone & 1.2 & meters per day \\
$\quad$ Galesville Sandstone & 0.3 & meters per day \\
\hline
\end{tabular}

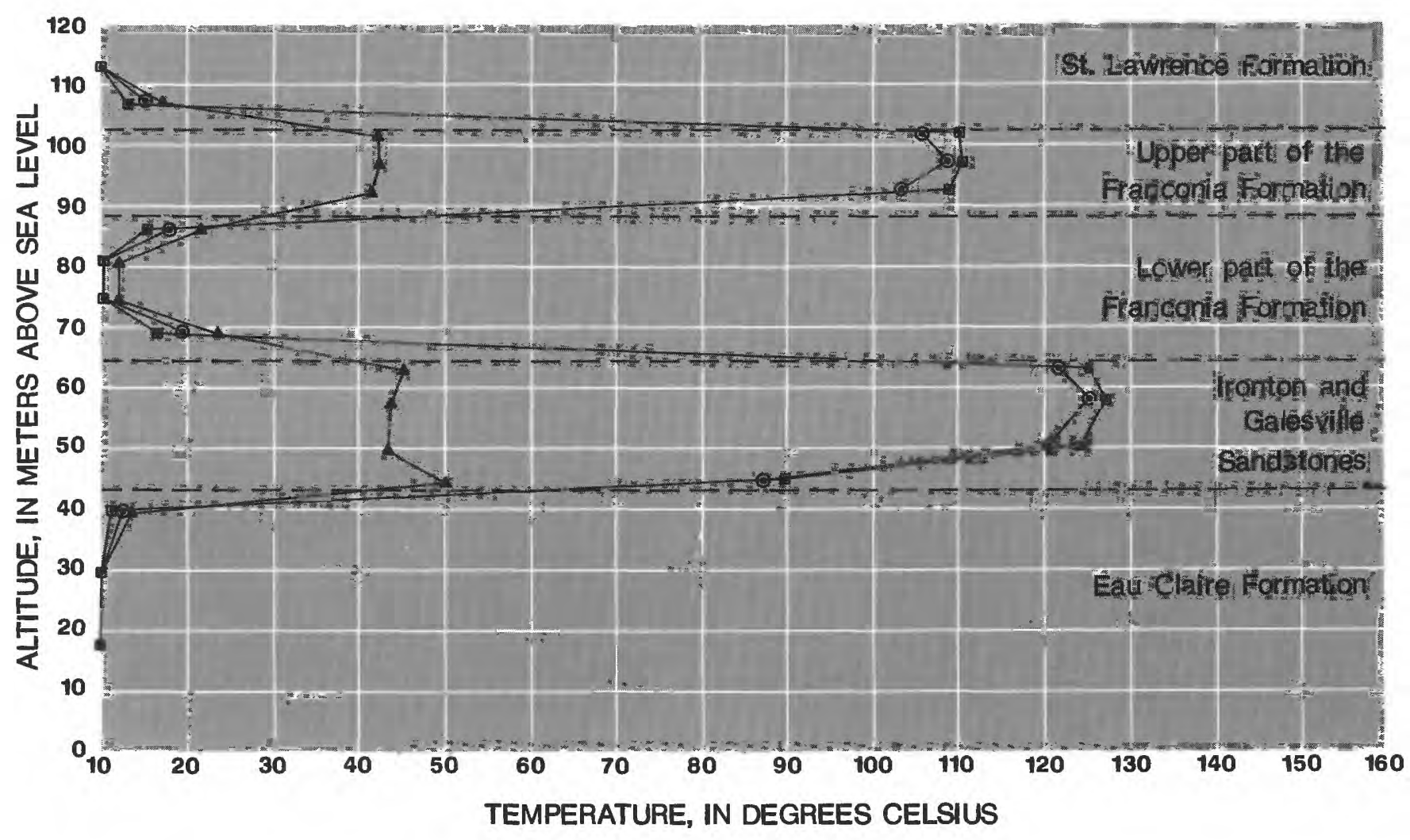

\section{EXPLANATION}

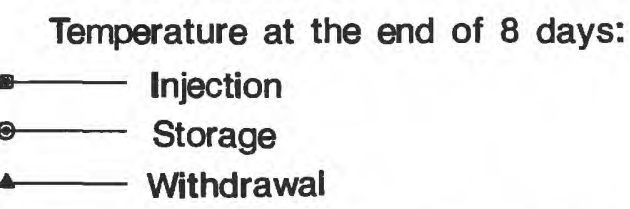

FIGURE 30.-Model-computed temperature profiles at the end of simulated injection, storage, and withdrawal for assumed base conditions.

same way as in the sensitivity analysis with 8 days of injection of $150^{\circ} \mathrm{C}$ water at $18.9 \mathrm{~L} / \mathrm{s}$, followed by 8 days of storage, and 8 days of withdrawal at $18.9 \mathrm{~L} / \mathrm{s}$. To examine the effect of buoyancy flow from natural convection and that from forced convection during injection and withdrawal, vertical temperature profiles were con- structed for the end of simulated injection, storage, and withdrawal periods.

Figure 30 illustrates temperature profiles at a radial distance of $6.5 \mathrm{~m}$ from the injection well for the base conditions (tables 9 and 10) used in the sensitivity analysis and with a $K_{H} / K_{V}$ ratio equal to 10 . At the end 


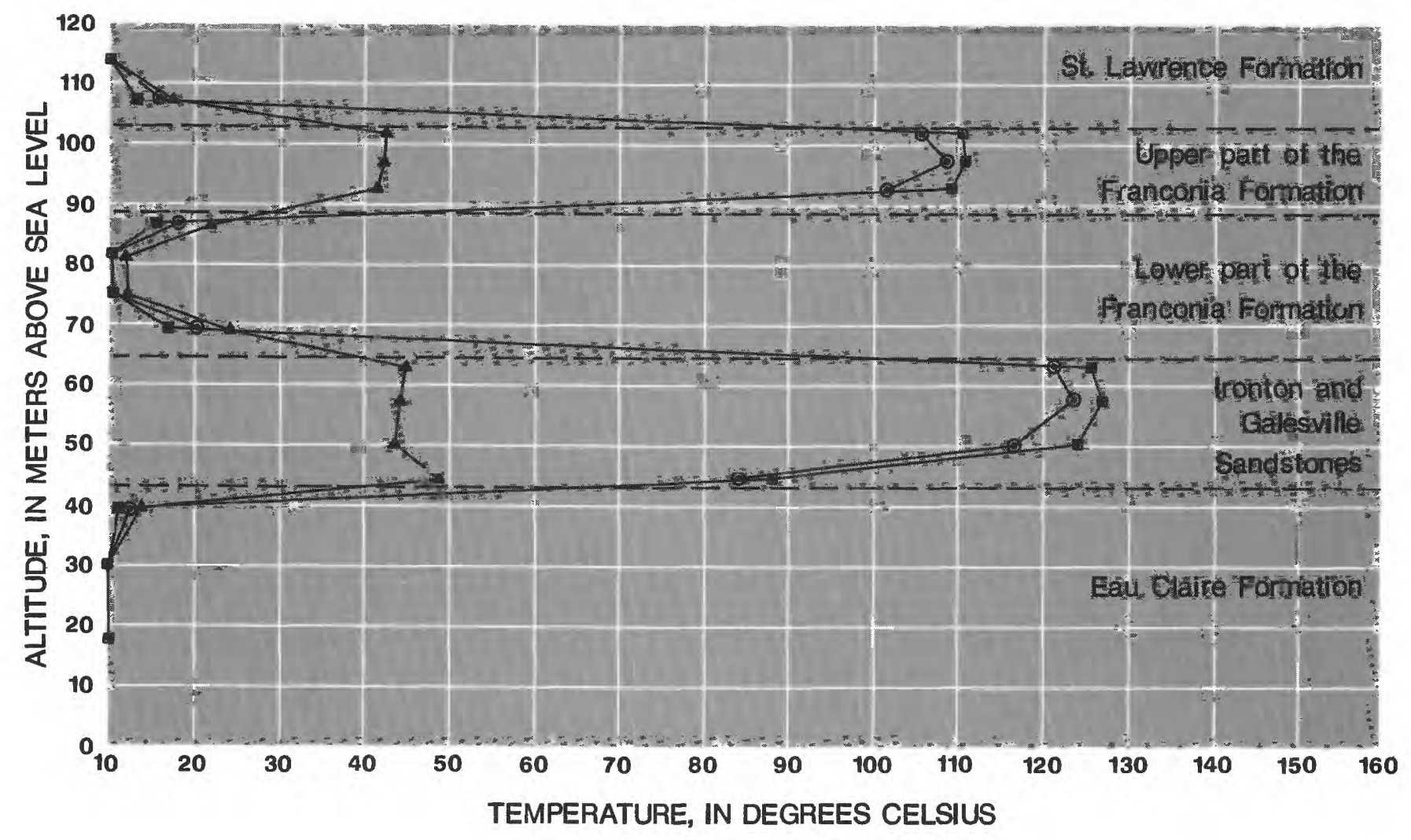

EXPLANATION

Temperature at the end of 8 days:

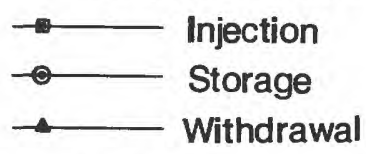

FIGURE 31. - Model-computed temperature profiles at the end of simulated injection, storage, and withdrawal for base conditions and horizontal equal to vertical hydraulic conductivity.

of simulated injection there is little evidence of buoyancy flow. The temperature profile illustrates vertical heat losses to the upper and lower confining units and to the lower part of the Franconia Formation. Vertical and horizontal heat losses are apparent after the storage period, but tilting of the thermal front is small. At the end of withdrawal, thermal tilting is not apparent. It should be noted that there is some vertical convection, which can be observed by comparing the modelcomputed temperatures in the confining units. At the end of the withdrawal period, the temperature within the upper confining unit (St. Lawrence Formation) is warmer than the temperature in the lower confining unit (Eau Claire Formation) even though the temperature in the Ironton and Galesville Sandstones is hotter than the temperature in the upper part of the Franconia Formation. Also, the temperatures in the lower part of the Franconia Formation continued to increase during with- drawal, indicating that heat conduction from above and below is greater than forced convection from pumping into or out of this part of the aquifer. If heat injected or conducted to the lower part of the Franconia Formation is not recoverable, the efficiency of the aquifer thermalstorage system could be significantly reduced.

Figure 31 illustrates the model-computed temperature profile for conditions similar to those in figure 30 except that horizontal and vertical hydraulic conductivity are equal. The computed temperature profiles in figure 31 are similar to figure 30 except for a slightly larger tilt in the thermal front after the storage period and slightly higher temperatures in the upper confining unit (St. Lawrence Formation) and the lowermost point in the lower part of the Franconia Formation. This difference is because simulation of a larger vertical hydraulic conductivity allowed for easier vertical heat conduction resulting in greater thermal stratification and buoyancy flow. 


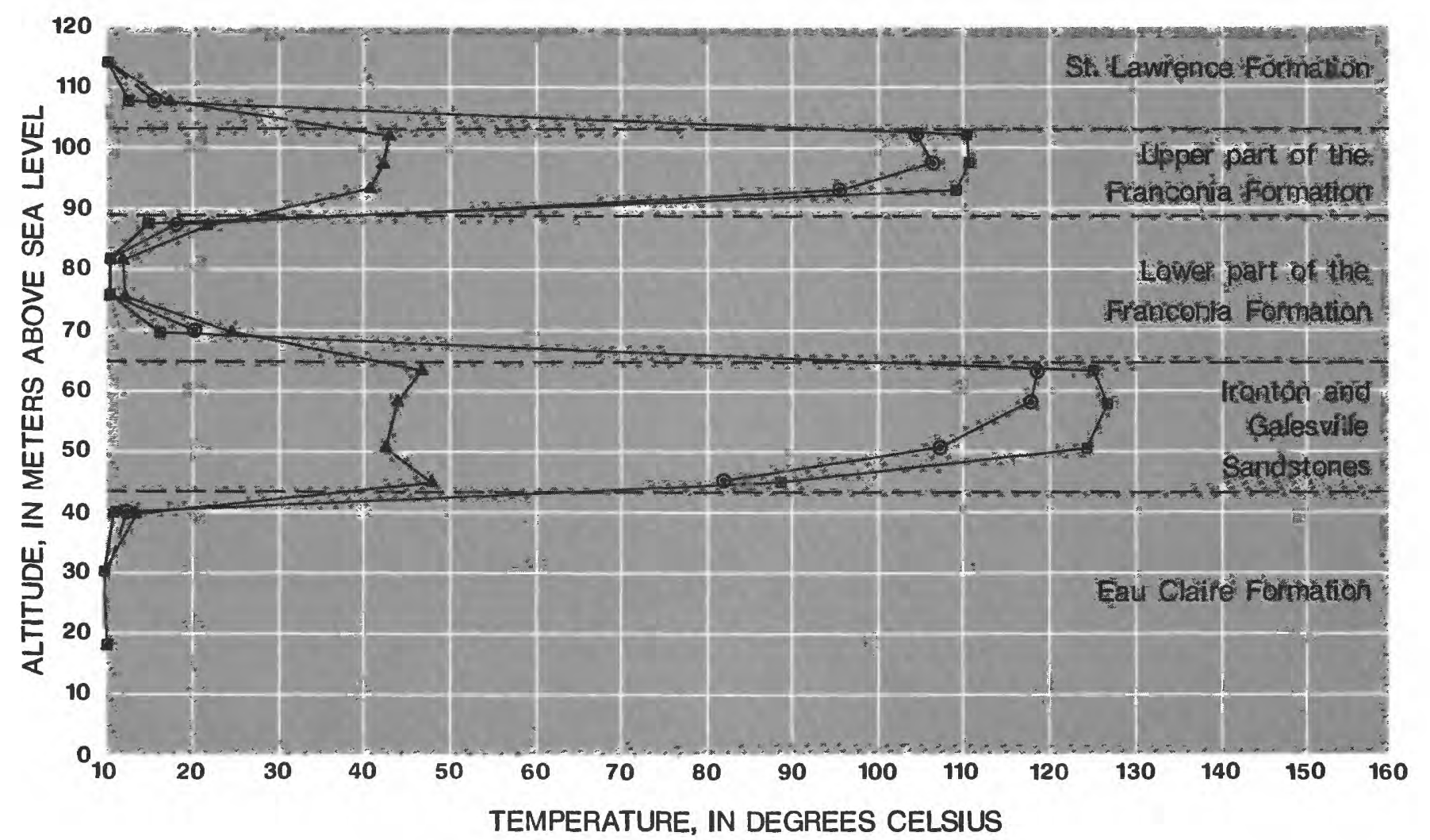

EXPLANATION

Temperature at the end of 8 days:

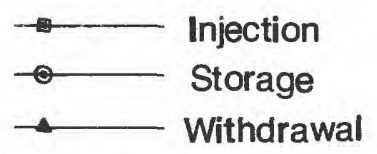

FIGURE 32.-Model-computed temperature profiles at the end of simulated injection, storage, and withdrawal for hydraulic conductivities equal to 10 times the base value.

The small amount of heat lost because of greater buoyancy is reflected in a calculated aquifer thermal efficiency 0.2 percent lower than the aquifer thermal efficiency calculated for base conditions.

To examine further the effects of buoyancy flow within the possible range of hydraulic conductivity for the aquifer, hydraulic conductivity was simulated as 10 times the base values (fig. 32). The computed temperature profiles at the end of the storage period are similar to those in figures 30 and 31 except in the Ironton and Galesville Sandstones where the thermal front is moderately tilted. Also, computed temperatures are higher in the upper part of the Ironton and Galesville Sandstones during the withdrawal period than in the previous simulation. These conditions resulted in greater heat loss to the lower part of the Franconia Formation and an aquifer thermal efficiency 1.3 percent lower than in the base simulation.
Figure 33 illustrates model-computed temperature profiles for hydraulic conductivities 10 times the base values and $K_{V}$ equal to $K_{H}$. Buoyancy flow is evident at the end of the storage and withdrawal periods by the thermal tilting produced in both the upper part of the Franconia Formation and in the Ironton and Galesville Sandstones. The greater buoyancy flow resulted in an aquifer thermal efficiency 2.9 percent lower than in the base simulation.

It is important to note that the temperature in the lower part of the Franconia Formation continued to increase throughout the simulated test cycle for each of the assumed conditions. Losses to the lower part of the Franconia Formation may result in a significantly lower thermal efficiency of the aquifer. A method for possible reduction of heat loss to this part of the aquifer may be to screen only the permeable parts of the upper Franconia Formation and the Ironton and Galesville Sandstones 


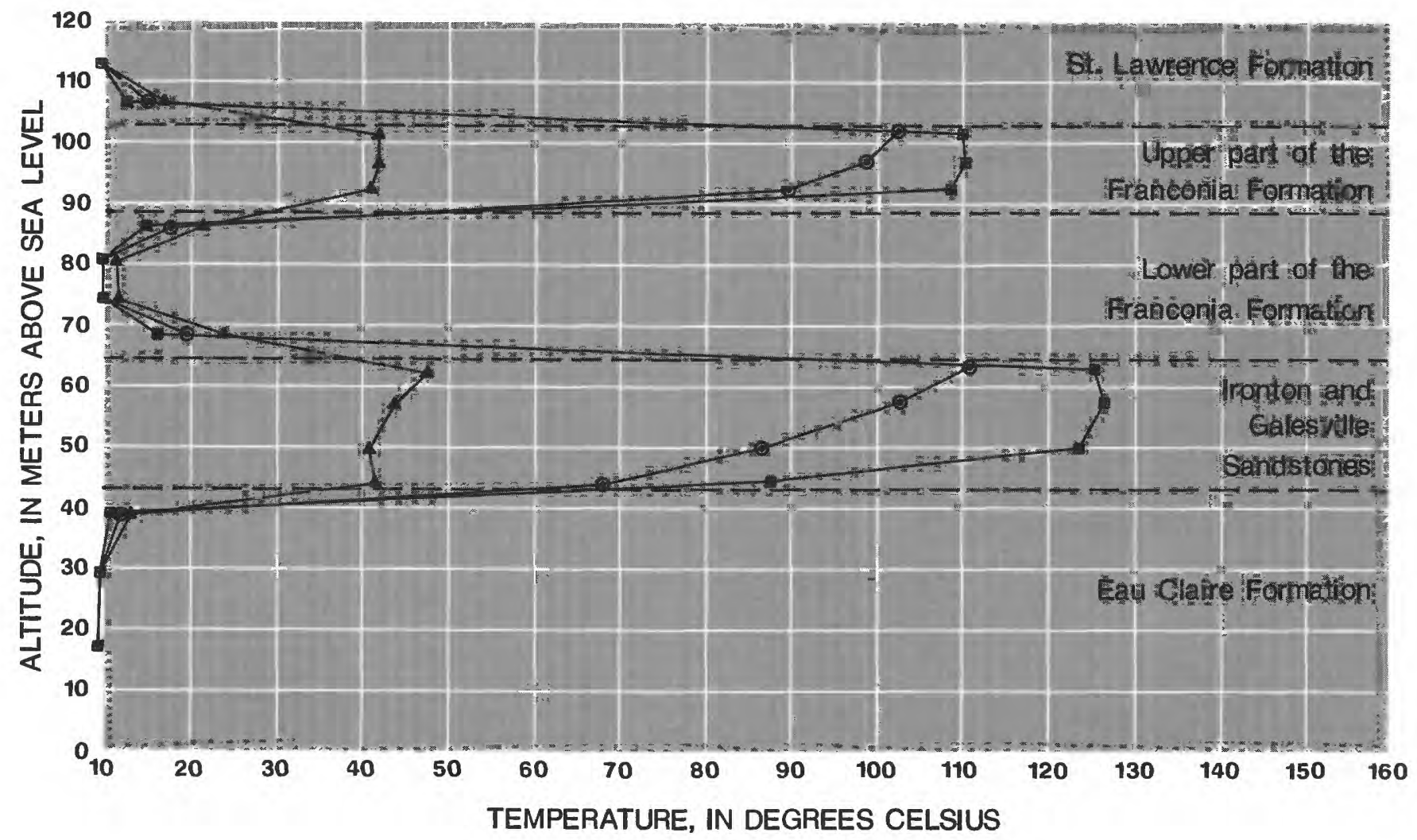

EXPLANATION

Temperature at the end of 8 days:

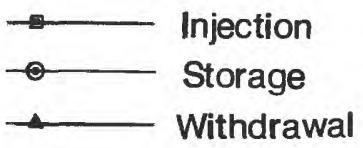

FIGURE 33. - Model-computed temperature profiles at the end of simulated injection, storage, and withdrawal for horizontal hydraulic conductivities equal to 10 times the base value and horizontal equal to vertical hydraulic conductivity.

and, thus, not inject hot water directly into the lower Franconia.

Finally, note that in simulations used to investigate buoyancy flow and tilting of the thermal front, only horizontal and vertical hydraulic conductivity were varied while other hydraulic and thermal properties were not. It is possible that other values of porosity, thermal dispersivity, rock-heat capacity, and thermal conductivity may produce different results for simulations of buoyancy flow.

\section{AQUIFER THERMAL EFFICIENCY}

The feasibility and success of an ATES system are determined by the amount of thermal energy that can be stored in and recovered from the aquifer. Aquifer thermal efficiency, expressed as a percentage, is calculated as the total energy withdrawn divided by the total energy injected. For base values of hydraulic and thermal properties, the flow and energy-transport model calculated a thermal efficiency of 51.0 percent for simulation of short-term test cycles. Although the model is sensitive to values of certain hydraulic and thermal characteristics in terms of calculated temperature, simulation of different values of the properties resulted in only small differences in calculated thermal efficiency. Generally these differences were less than 2 percent; however, when thermal-dispersivity values were changed, differences in calculated thermal efficiencies were approximately 7 percent. In terms of estimating aquifer thermal efficiency, the model sensitivity analysis only indicated the possible range of thermal efficiency based on possible ranges in values of hydraulic and thermal properties. Better definition of these properties is needed to improve model estimates of efficiency. 


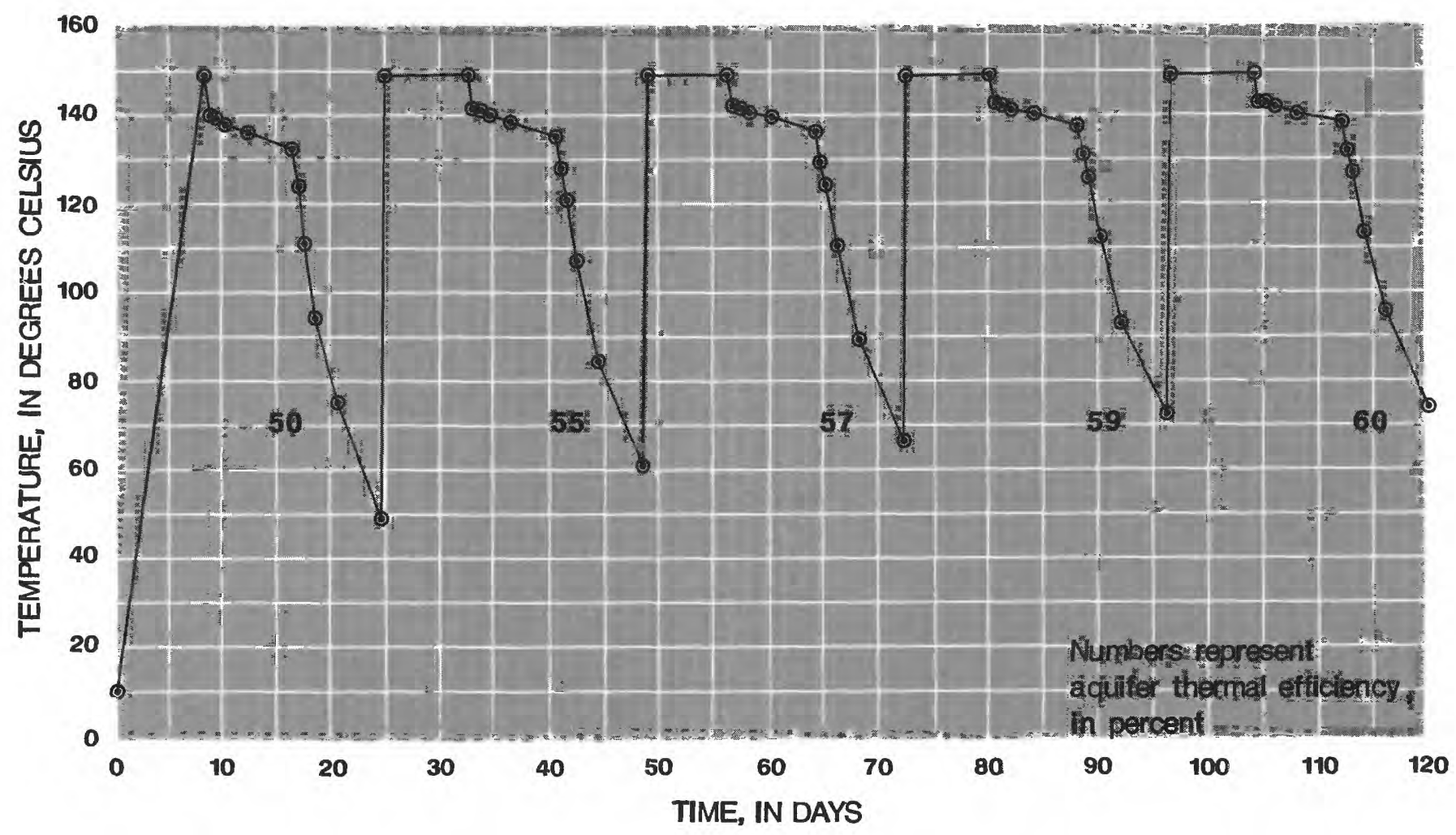

FIGURE 34.-Model-computed well-bore temperatures and aquifer thermal efficiencies for five sequential 24-day test cycles.

The sensitivity analysis indicated which properties need to be defined more precisely to make the model estimate as accurate as possible. However, in addition to the physical properties of the aquifer system, there are also operational factors that affect the thermal efficiency of the ATES system. These factors include temperature of injected water, rate of injection and withdrawal, and duration of injection, storage, and withdrawal. To test the effects of these factors on thermal efficiency, a series of model simulations was performed in which these factors were varied and the results compared. Base values of hydraulic and thermal properties were used in all these simulations.

\section{RADIAL FLOW SIMULATIONS}

The ability of the preliminary radial-flow model to simulate the ATES doublet-well system is related to the radial distance that heat will move from the well for the period of simulation. Model-computed temperatures for the short-term-cycle simulations (fig. 34 ) indicated that injected heat was contained within a radial distance of approximately $20 \mathrm{~m}$. This radial distance is shown in figure 21. Comparison of the equipotentials for the doublet-well system and the 20-m, model-computed, radial extent of heat indicated that the short-term-cycle simulations were representative of the doublet-well system.

The longer term simulations (figs. 35 to 38 ) indicated that heat would be contained within an $85-\mathrm{m}$ radial distance for the 6-month injection periods and a $90-\mathrm{m}$ radial distance for the 8-month injection periods. These two radial distances are plotted on figure 21 . A comparison of the 85-m and 90-m radial distances with the equipotentials for the doublet-well system indicates that the preliminary model radial-flow assumption may not adequately represent the doublet-well system for the longer-term cycles. However, the usefulness of the results of the preliminary model long-term simulations is not affected because the purpose of the simulations is to describe how the operational factors of injection and withdrawal rates and duration can affect the aquifer efficiency. The aquifer efficiencies calculated from the long-term simulations are termed relative. Although they may not exactly represent efficiencies that would be calculated from the working ATES doublet-well system, they are comparable to each other and, thus, serve the intended purpose.

In this study, short-term testing cycles are defined as 8 days of injection at $18.9 \mathrm{~L} / \mathrm{s}$ of $150^{\circ} \mathrm{C}$ water, 8 days of storage, and 8 days of withdrawal at $18.9 \mathrm{~L} / \mathrm{s}$ for a total cycle of 24 days. Figure 34 shows a plot of model- 


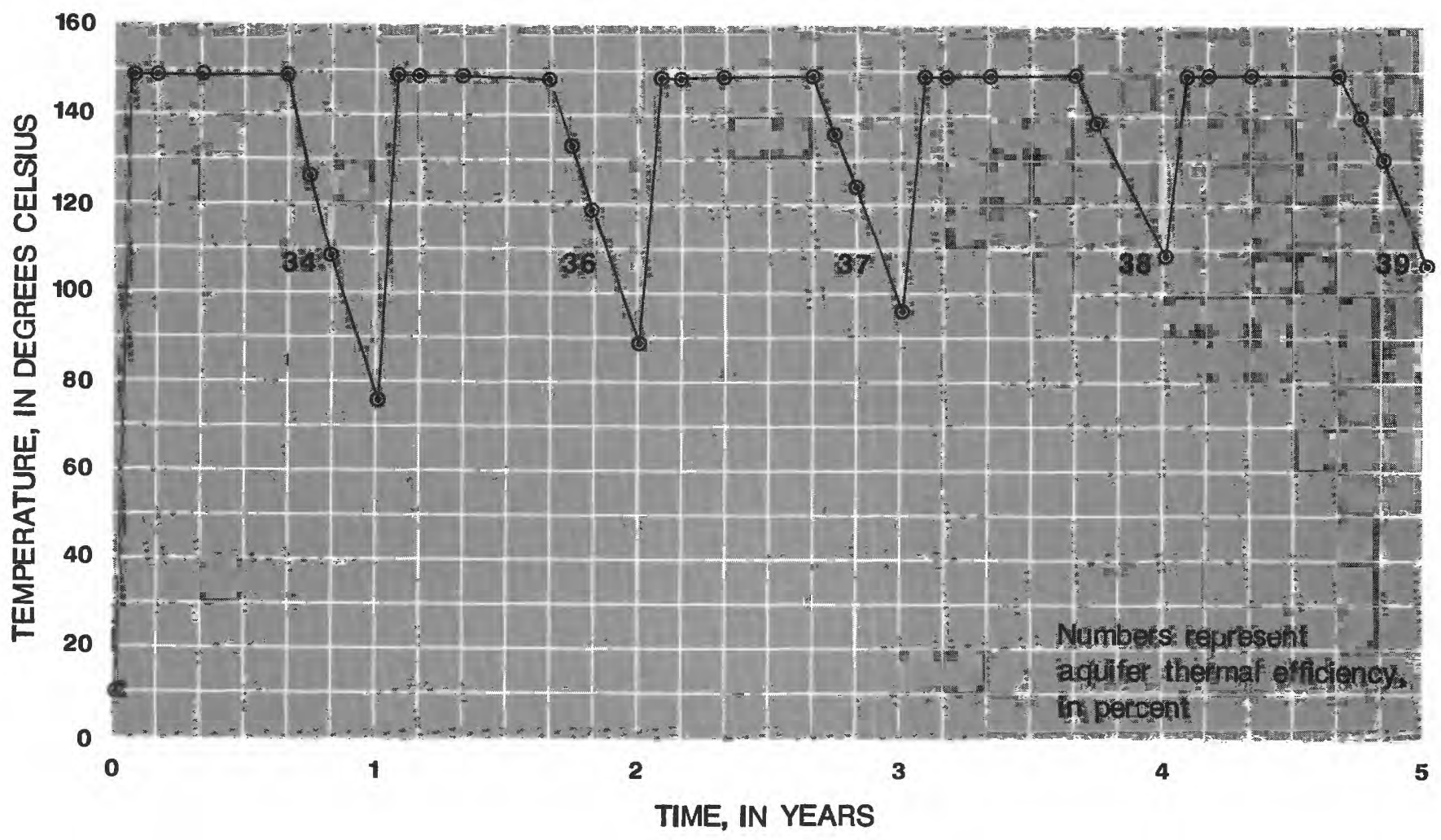

FIGURE 35. - Model-computed well-bore temperatures and aquifer thermal efficiencies for five sequential 1-year cycles, each consisting of 8-months injection at 18.9 liters per second and 4-months withdrawal at 18.9 liters per second.

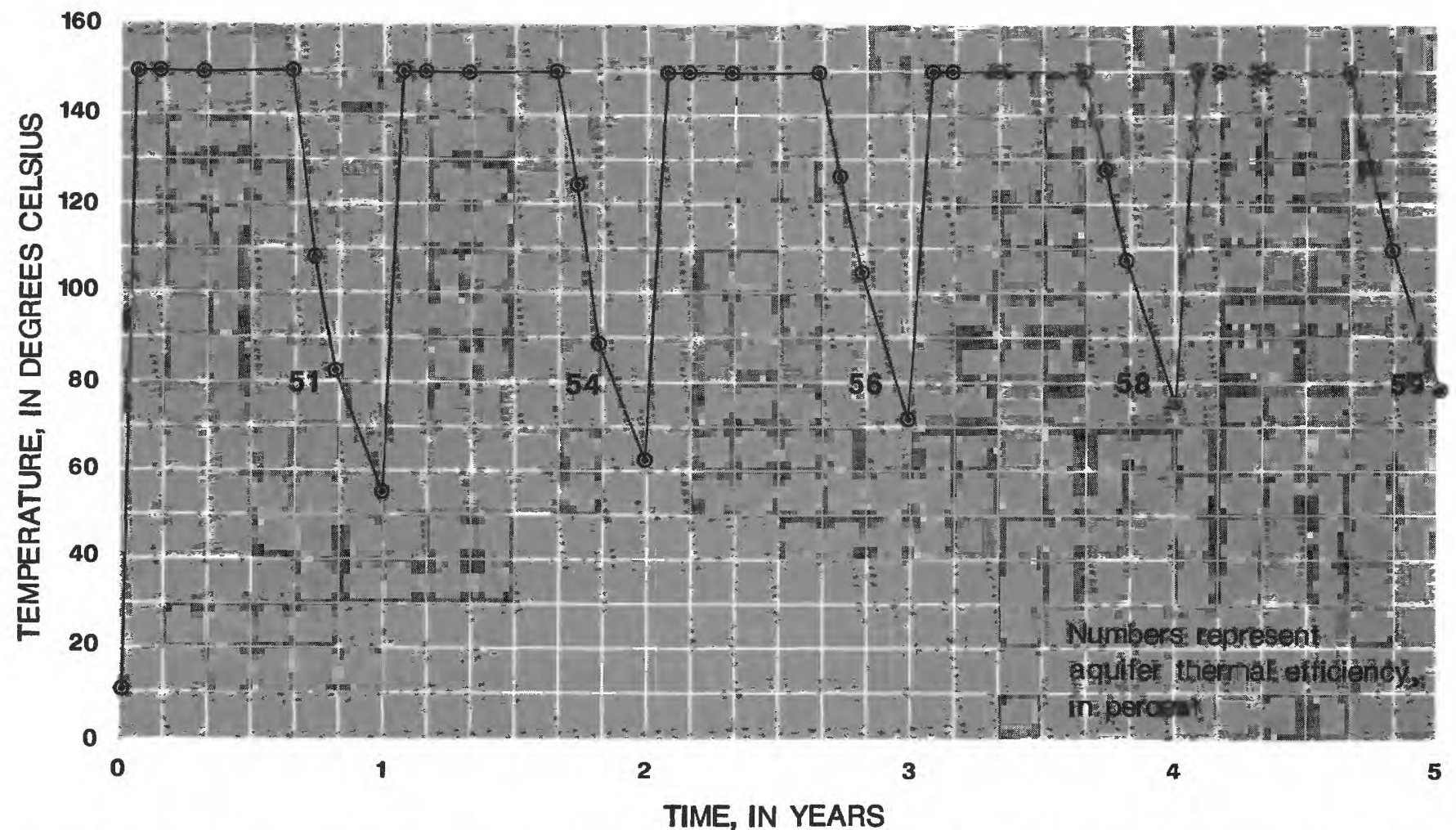

FIGURE 36. - Well-bore temperatures and calculated aquifer relative efficiencies for five hypothetical 1-year cycles, each consisting of 8-months injection at 18.9 liters per second of $150^{\circ} \mathrm{C}$ water and 4-months withdrawal at 37.7 liters per second. 


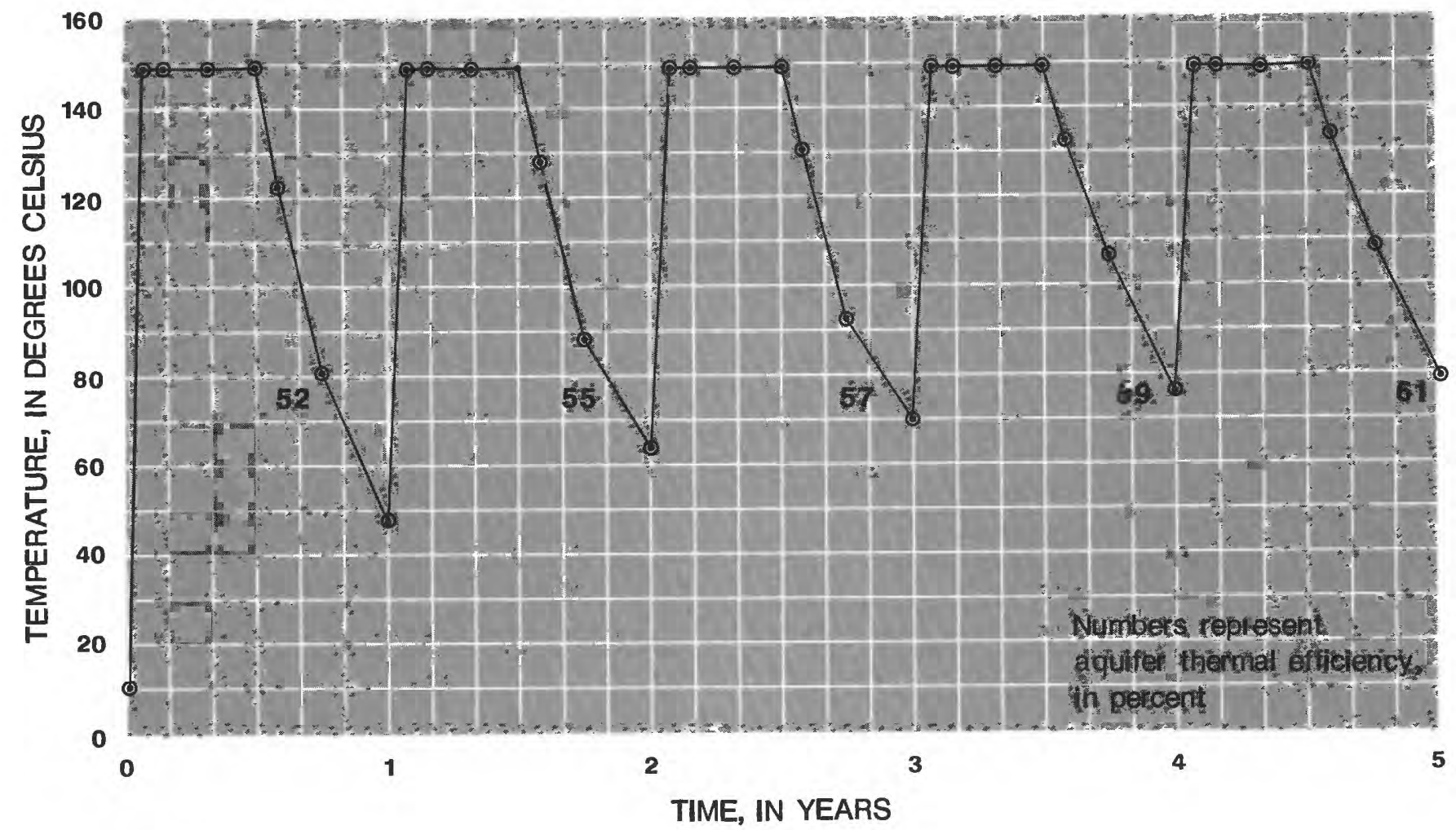

FIGURE 37. - Well-bore temperatures and calculated aquifer relative efficiencies for five hypothetical 1-year cycles, each consisting of 6-months injection at 18.9 liters per second of $150^{\circ} \mathrm{C}$ water and 6 -months withdrawal at 18.9 liters per second.

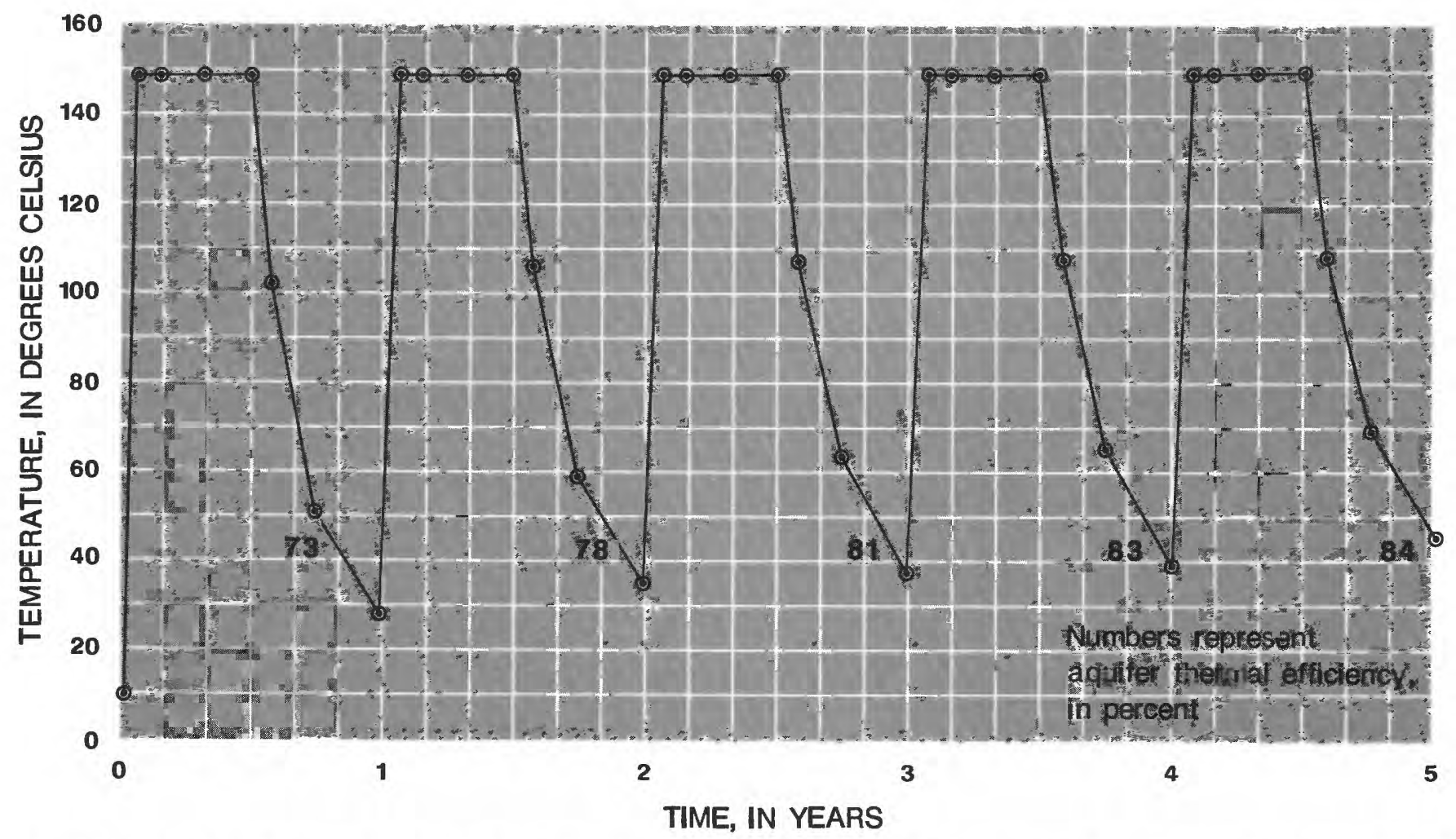

FIGURE 38.-Well-bore temperatures and calculated aquifer relative efficiencies for five hypothetical 1-year cycles, each consisting of 6-months injection at 18.9 liters per second of $150^{\circ} \mathrm{C}$ water and 6 -months withdrawal at 37.8 liters per second. 
computed well-bore temperatures versus time for five sequential 24-day cycles as simulated by the base radialflow model. Also indicated at the end of each 24-day cycle is the aquifer thermal efficiency. The plot indicates that for the short-term test cycles, the aquifer thermal efficiency tends to increase with successive cycles. This increase in efficiency results because the first cycle of injected water heats up the aquifer from its initial ambient temperature of approximately $10^{\circ} \mathrm{C}$. At the beginning of subsequent injections, the aquifer is warmer due to residual heat that was not completely recovered from the previous cycle. The graph also indicates that the aquifer thermal efficiency will approach a maximum value after several cycles. For the simulation depicted in figure 34, the maximum aquifer efficiency probably would be between 60 and 65 percent.

A working ATES system would not operate on the short-term (24-day) test cycles, but rather on yearly cycles based on seasonal thermal-energy surplus and demand. Figure 35 shows model-computed well-bore temperatures and relative thermal efficiencies for five continuous 1-year cycles of 8 months of injection at 18.9 $\mathrm{L} / \mathrm{s}$ and $150^{\circ} \mathrm{C}$ and 4 months of withdrawal at $18.9 \mathrm{~L} / \mathrm{s}$. The model conditions are similar to those previously described for the five 24-day cycles. Relative aquifer thermal efficiencies range from 34 to 39 percent and well-bore temperatures at the end of withdrawal range from approximately 80 to $105^{\circ} \mathrm{C}$.

Figure 36 shows model-computed well-bore temperatures and relative aquifer thermal efficiencies for conditions similar to those shown in figure 35 except that the withdrawal rate is $37.7 \mathrm{~L} / \mathrm{s}$. The relative aquifer thermal efficiency ranges from 51 to 59 percent and the well-bore temperature at the end of each cycle ranges from approximately 55 to $78^{\circ} \mathrm{C}$.

Figure 37 shows model-computed well-bore temperatures and relative aquifer thermal efficiencies calculated for five continuous 1-year cycles each consisting of 6 months of injection at $18.9 \mathrm{~L} / \mathrm{s}$ and $150^{\circ} \mathrm{C}$ and 6 months of withdrawal at $18.9 \mathrm{~L} / \mathrm{s}$. Relative aquifer thermal efficiency at the end of each cycle ranges from 52 to 61 percent and the well-bore temperature at the end of each cycle ranges from approximately 46 to $78^{\circ} \mathrm{C}$.

Figure 38 shows model-computed well-bore temperatures and relative aquifer thermal efficiencies calculated for conditions similar to figure 37 except that the withdrawal rate is $37.8 \mathrm{~L} / \mathrm{s}$. Relative aquifer thermal efficiencies are the highest of any of the simulations and range from 73 to 84 percent. This simulation also produces the lowest well-bore temperatures at the end of each cycle, ranging from approximately 27 to $45^{\circ} \mathrm{C}$.

To summarize, figures 35 through 38 illustrate relative aquifer thermal efficiencies and well-bore temperatures based on 1-year cycles with hypothetical injection and withdrawal rates and periods. A comparison of the graphs shows that operational methods that increase aquifer thermal efficiency also lower well-bore temperatures at the completion of each cycle. Thus, for a working ATES system, a required minimum well-bore temperature may also limit the aquifer thermal efficiency. The simulations shown in figures 34 through 38 also demonstrate one method for developing an optimization scheme for a working ATES system by use of a calibrated ground-water-flow and thermal-energy-transport model.

\section{THREE-DIMENSIONAL MODEL}

Analysis of aquifer-test data described earlier indicates that the upper Franconia and Ironton-Galesville parts of the aquifer are areally anisotropic and at an angle of approximately 30 degrees between the major axis of transmissivity and the axis between the two wells. Although the anisotropy may be considered to be small (less than 3:1), its effect on the movement and direction of heat flow for these particular hydrologic conditions is not known. Reducing the problem to one of radial-flow would neglect this anisotropic effect. The potential errors introduced in the radial-flow assumptions were examined earlier in the section describing the radial-flow model. Based on that discussion, it was decided to construct a three-dimensional model to more accurately represent field conditions and simulate the ATES short-term tests. This section describes the construction and calibration of the isothermal hydraulic-flow part of the model that incorporates the effects of anisotropy.

\section{FINITE-DIFFERENCE GRID DESIGN}

The area around the ATES doublet-well system that can be modeled is severely limited by (1) constraint on the finite-difference grid spacings inherent in the model solution techniques, (2) the fact that the axis of maximum transmissivity and the axis on which the doublet wells are located are not aligned, and (3) the large cost of running the model for large three-dimensional problems. Miller and Voss (1986) describe an analytical solution for steady flow in an isothermal, anisotropic, doublet-well system. They describe a method to simplify and reduce the simulated region to a computationally small size while retaining the main physical attributes of the flow and energy-transport regime. The procedure begins with an analytical solution for flow in an isotropic, isothermal, doublet-well system and modifies the solution for the effects of anisotropy and the nonalignment of principal directions of hydraulic conductivity with the doublet-well axis. 
Bear (1972, p. 320) gives the analytical solution for a two-dimensional flow field around a doublet-well system in an infinite, isotropic, isothermal, confined aquifer where one well is withdrawing water and the other is injecting water at the same rate. In terms of the velocity potential $(\Phi)$ and stream lines $(\Psi)$ the solution can be written

$$
\Phi=\frac{Q}{4 \pi b} \ln \frac{\left(X_{B}+d_{B}\right)^{2}+Y_{B}^{2}}{\left(X_{B}-d_{B}\right)^{2}+Y_{B}^{2}}
$$

Since $\Phi=K \phi$ it follows that

$$
\phi=\frac{Q}{4 \pi K b} \ln \frac{\left(X_{B}+d_{B}\right)^{2}+Y_{B}^{2}}{\left(X_{B}-d_{B}\right)^{2}+Y_{B}^{2}}
$$

finally $T=K b$ therefore

$$
\begin{gathered}
\phi=\frac{Q}{4 \pi T} \ln \frac{\left(X_{B}+d_{B}\right)^{2}+Y_{B}{ }^{2}}{\left(X_{B}-d_{B}\right)^{2}+Y_{B}{ }^{2}} \\
\Psi=\frac{Q}{4 \pi b} \tan ^{-1}\left(\frac{-2 Y_{B} d_{B}}{X_{B}{ }^{2}+Y_{B}{ }^{2}-d_{B}{ }^{2}}\right)
\end{gathered}
$$

where

$$
\begin{aligned}
X_{B}, Y_{B} & =\text { orthogonal coordinates }[l](\mathrm{m}), \\
d_{B} & =\text { one-half distance between two wells }[l](\mathrm{m}), \\
Q= & =\text { rate of flow of source and sink }\left[l^{3} / t\right]\left(\mathrm{m}^{3} / \mathrm{s}\right), \\
T & =\text { aquifer transmissivity, }\left[l^{2} / t\right]\left(\mathrm{m}^{2} / \mathrm{s}\right), \\
b= & \text { aquifer thickness, }[l](\mathrm{m}), \\
K & =\text { aquifer hydraulic conductivity, }[l / t](\mathrm{m} / \mathrm{s}), \\
& \text { and } \\
\phi & =\text { equipotential, }[l](\mathrm{m}) .
\end{aligned}
$$

The first step involves describing the isotropic coordinate system $X_{B}, Y_{B}$, in terms of a rotated coordinate system $X_{i}, Y_{i}$, and $\theta$, where $\theta$ is the angle between the $X_{i}$ and $X_{B}$ axes. Taking the inverse transform and expressing it in matrix notation,

$$
\left[\begin{array}{c}
X_{B} \\
Y_{B}
\end{array}\right]=\left[\begin{array}{c}
\cos \theta \sin \theta \\
-\sin \theta \\
\cos \theta
\end{array}\right]\left[\begin{array}{c}
X_{i} \\
Y_{i}
\end{array}\right]
$$

Then take the transformation from an anisotropic to an equivalent isotropic coordinate system described by Freeze and Cherry (1979) as

$$
\begin{gathered}
X_{i}=X_{f} \\
Y_{i}=Y_{f}\left(\frac{K_{x f}}{K_{y f}}\right)^{1 / 2}
\end{gathered}
$$

where $X_{f}, Y_{f}$ are the true field coordinates in the anisotropic system, and $K_{x f}, K_{y f}$ are the respective maximum and minimum values of horizontal hydraulic conductivity, where $K_{x f}$ is aligned in the $X_{i}$ direction. For the case where the thickness of the confined aquifer is constant, equation 30 may be written in terms of transmissivity as

$$
Y_{i}=Y\left(\frac{T_{x f}}{T_{y f}}\right)^{1 / 2}
$$

Substituting 29, 30, and 31 into 28 and solving for $X_{B}$ and $Y_{B}$ yields

$$
\begin{gathered}
X_{B}=X_{f} \cos \theta+Y_{f}\left(\frac{T_{x f}}{T_{y f}}\right)^{1 / 2} \sin \theta \\
Y_{B}=-X_{f} \sin \theta+Y_{f}\left(\frac{T_{x f}}{T_{y f}}\right)^{1 / 2} \cos \theta
\end{gathered}
$$

which are the coordinates of the isotropic flow-field solution expressed in an anisotropic nonaligned fieldcoordinate system. As described by Miller and Voss (1986) one further correction to the values of $\theta$ and $d_{B}$ is necessary to express them as the true distance between the wells $\left(d_{f}\right)$, and the true field angle $\left(\theta_{f}\right)$ from the maximum transmissivity direction to the well axis. This expression is

$$
d_{B}=\left(\frac{T_{x f}}{T_{y f}}\right)^{1 / 2}\left(\frac{d_{f} \sin \theta_{f}}{\sin \theta}\right)
$$

where $\theta$ is described by

$$
\theta=\tan ^{-1}\left[11 /\left(\tan \theta_{f}\right)\left(\frac{T_{x f}}{T_{y f}}\right)^{1 / 2}\right]
$$

The values of $X_{B}, Y_{B}$ and $d_{B}$ described by equations 32 , 33 , and 34 , respectively, can be substituted into equations 26 and 27 for a description of equipotentials and streamlines in an anisotropic system where the major axis is not aligned with the doublet-well axis.

Figures 39 and 40 illustrate the flow net for the solution to equations 26 and 27 for the Ironton and Galesville Sandstones and the upper part of the Franconia Formation, respectively. It was generated using the average horizontal hydraulic-conductivity data in table 9 and for rates of $15.1 \mathrm{~L} / \mathrm{s}$ for the Ironton and Galesville Sandstones and $3.8 \mathrm{~L} / \mathrm{s}$ for the upper part of the Franconia Formation. The equipotentials and streamlines illustrated in figures 39 and 40 are the steady-state solution to the two-dimensional isothermal flow in a homogeneous, confined, infinite, anisotropic aquifer that has no regional hydraulic gradient. For practical purposes, the Franconia-Ironton-Galesville aquifer may be treated as infinite because it has no lateral boundaries within several miles (Kanivetsky, 1978). The regional gradient was estimated as less than $10^{-3}$, which is taken 


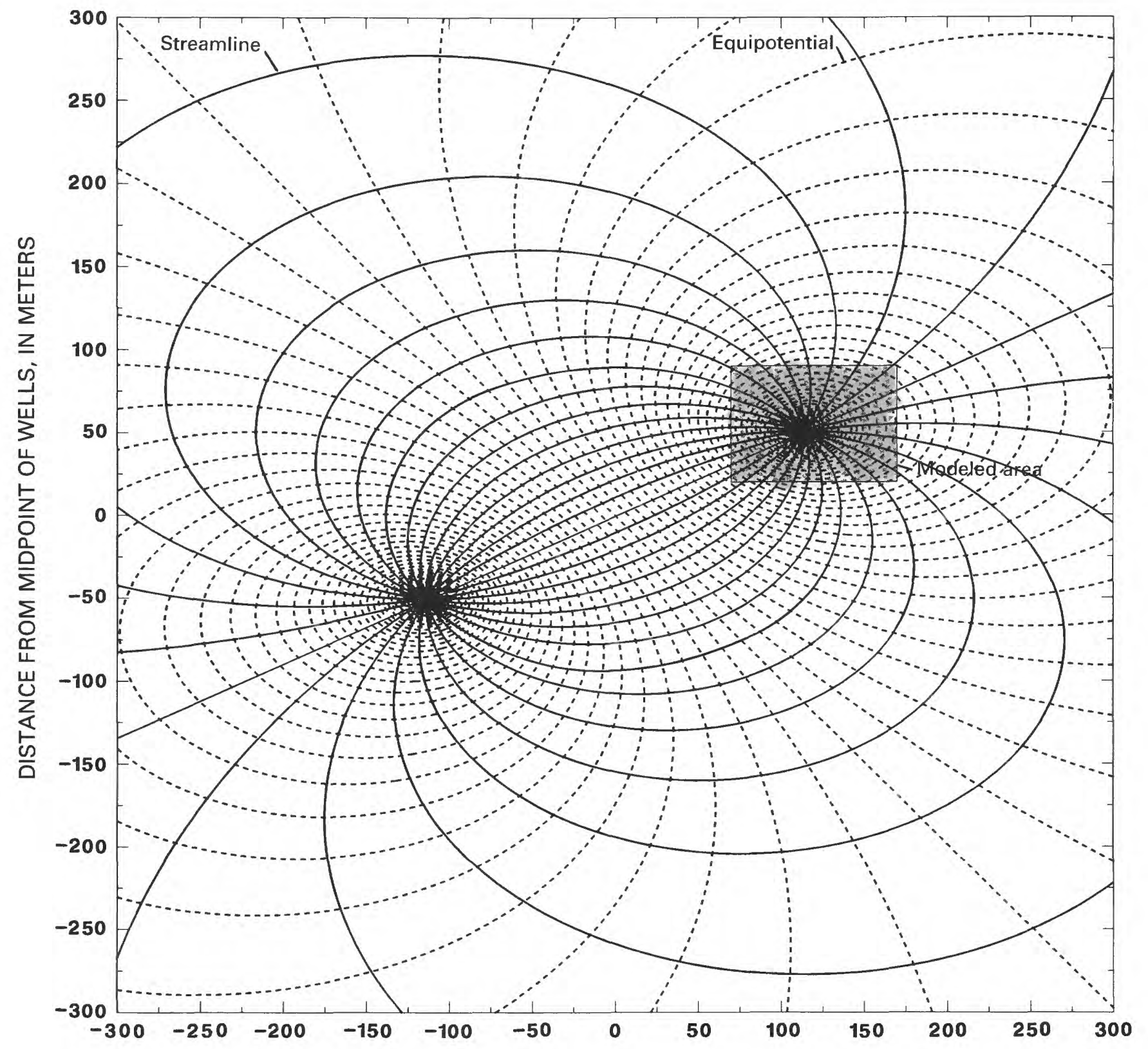

DISTANCE FROM MIDPOINT OF WELLS, IN METERS

Figure 39. - Flow net for the Ironton and Galesville Sandstones for the doublet-well system and location of the modeled area near production well A. (From Miller and Voss, 1986.)

to be negligible. The Ironton and Galesville Sandstones are effectively confined above by the lower part of the Franconia Formation, because the transmissivity of the lower part of the Franconia Formation is approximately one order of magnitude less than the transmissivity of Ironton and Galesville Sandstones. The upper part of the Franconia Formation also is confined below by the lower part of the Franconia Formation.
The finite-difference model grid was aligned with the principal axes of transmissivity, with the horizontalcoordinate direction being the direction of the maximum transmissivity. The origin of the field coordinate system shown in figures 39 and 40 was arbitrarily chosen to be halfway between the wells.

A finite-difference grid for a ground-water-flow model generally is constructed with cells as large as possible to 


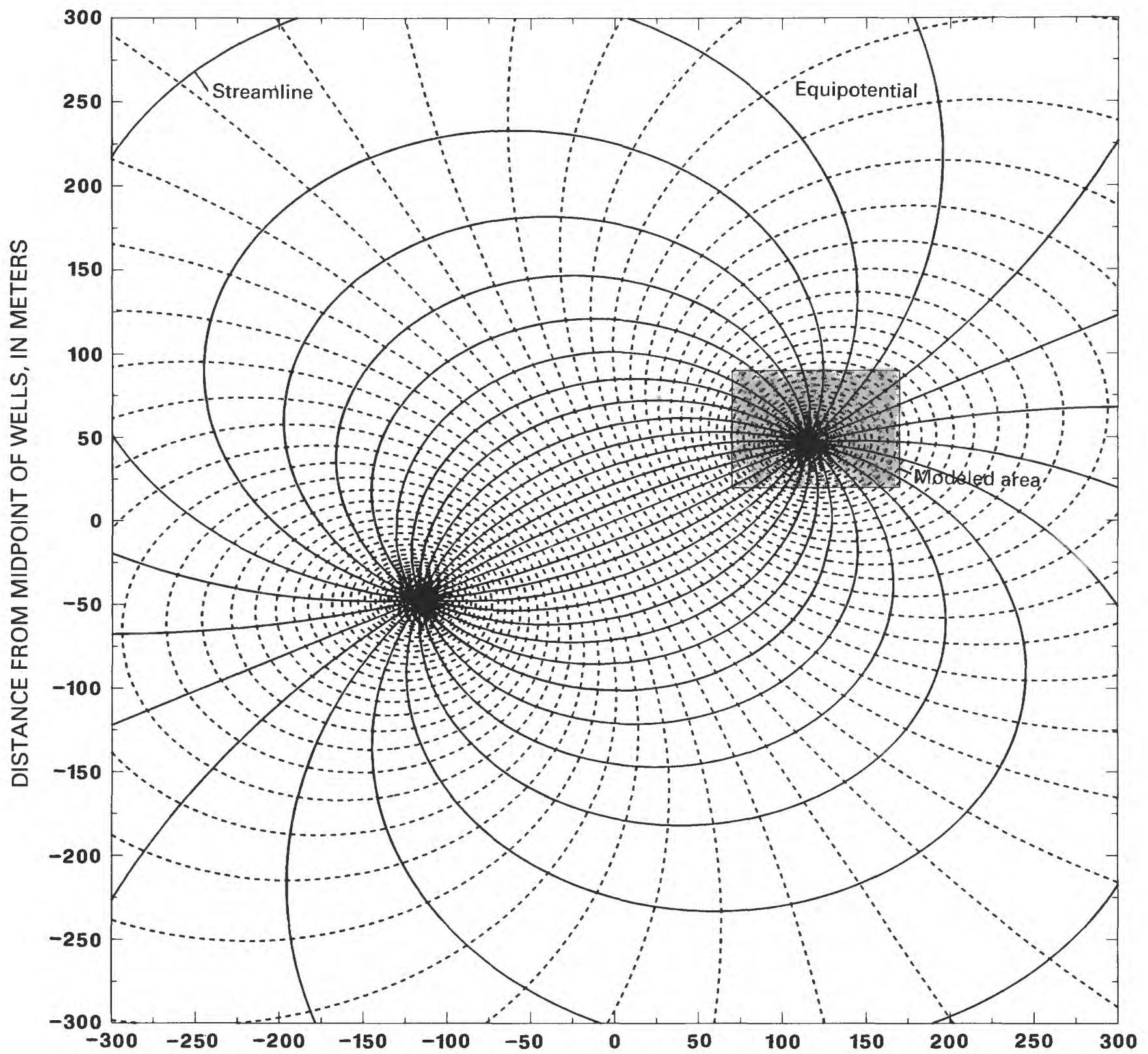

DISTANCE FROM MIDPOINT OF WELLS, IN METERS

FiguRe 40. - Flow net for the upper part of the Franconia Formation for doublet-well system and the location of the modeled area near production well A. (From Miller and Voss, 1986.)

reduce computer storage requirements and computation time while maintaining adequate model accuracy in space. The maximum cell size is determined by the nature of the finite-difference approximation of the ground-water-flow and transport equations. For the solution of transport equations, large cell dimensions may cause oscillations in the distribution of the transported quantity in space. To remedy this, Intercomp
(1976) suggests a restriction on the selection of cell sizes based on the approximate value of the hydrodynamic dispersivity: the cell size should be less than twice the value of dispersivity.

Although it is possible to construct a finite-difference grid that would encompass the entire area illustrated in figures 39 and 40 and would accurately simulate the doublet-well system, the number of resulting cells and 


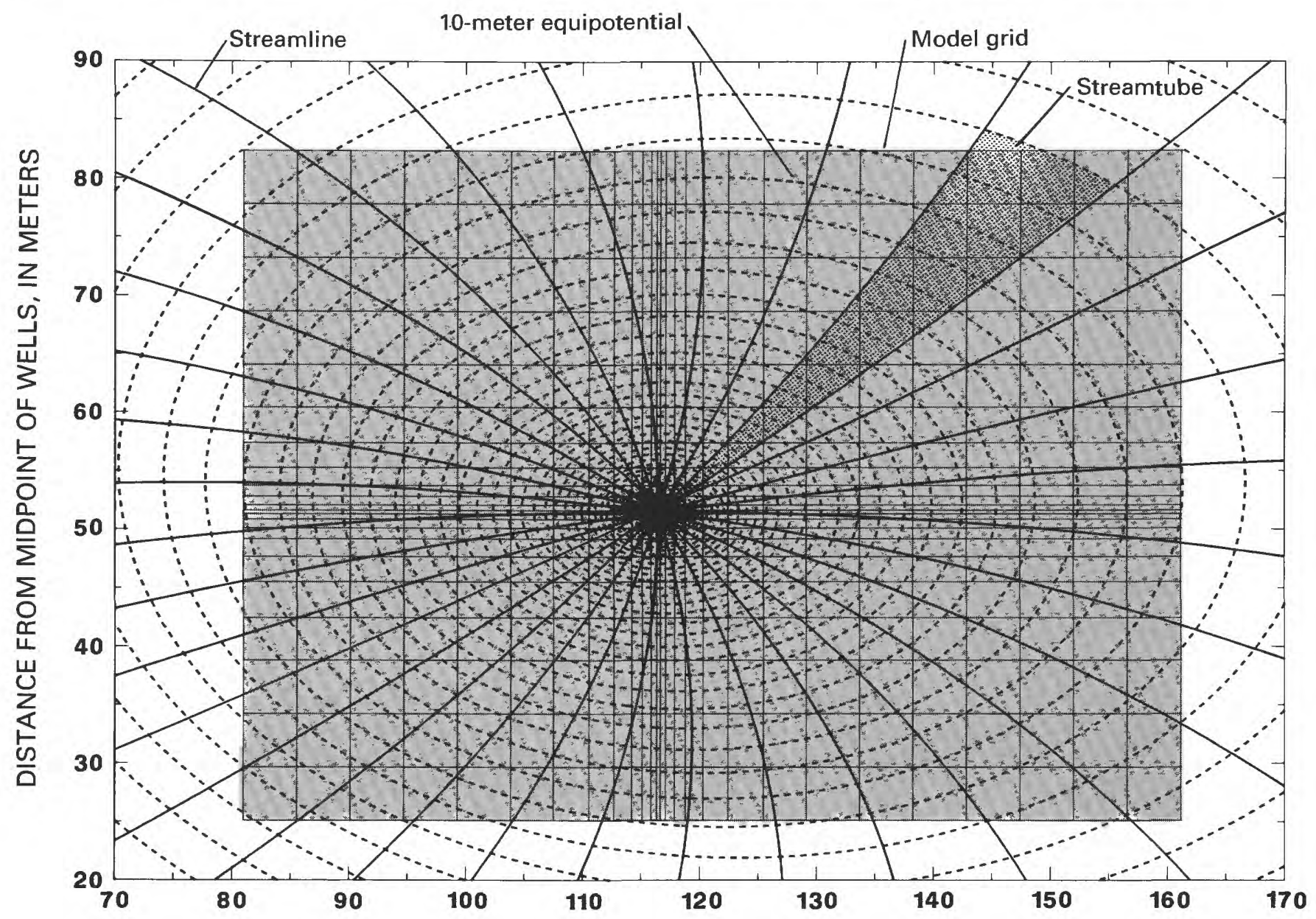

DISTANCE FROM MIDPOINT OF WELLS, IN METERS

Figure 41.-Model grid and flow net for the Ironton and Galesville Sandstones near production well A.

corresponding calculations would be too costly to model with the SWIP code. However, the flow-net analysis described previously makes it possible to reduce the modeled area and simulate flow only in the area around the injection well. This flow region around the well is of greatest concern because this is where energy transport is most prominent. Flow outside this region is represented with prescribed fluxes at model boundaries determined by flow-net analysis.

Figures 41 and 42 illustrate an enlargement of the boxed flow field around the injection well shown in figures 39 and 40, respectively. Because of restrictions on grid size for solution accuracy and stability based on a central-difference-space and backward-difference-time solution method used in the SWIP code (Intercomp, 1976), a variable grid of 22 rows and 27 columns was designed. Cell sizes range from $0.3 \mathrm{~m}$ by $0.3 \mathrm{~m}$ in the center of the grid at the injection well to a maximum of $4.6 \mathrm{~m}$ by $4.6 \mathrm{~m}$, increasing in all directions equally by a factor of 1.5 or less. The model grid covers about 4,800 $\mathrm{m}^{2}$ and has 594 cells per layer. A three-dimensional view of the finite-difference grid is illustrated in figure 43.

Vertical grid spacings were selected to correspond with the four hydraulic zones in the aquifer and with the overlying and underlying confining units. Table 11 summarizes the vertical grid spacing by model layer number shown in figure 43 , the thickness of the layer, and the corresponding hydrogeologic unit. The lateral boundaries of the model correspond to the $10-\mathrm{m}$ equipotential for the Ironton and Galesville Sandstones (fig. 41) and to the 2.9-m equipotential for the upper part of the Franconia Formation (fig. 42). These model boundaries require specified flux rates to accurately simulate the flow field shown in figures 39 and 40.

\section{FLUX CALCULATION AT MODEL BOUNDARIES}

The correct boundary fluxes may be determined based on an analysis of the flow net for steady-state conditions. 


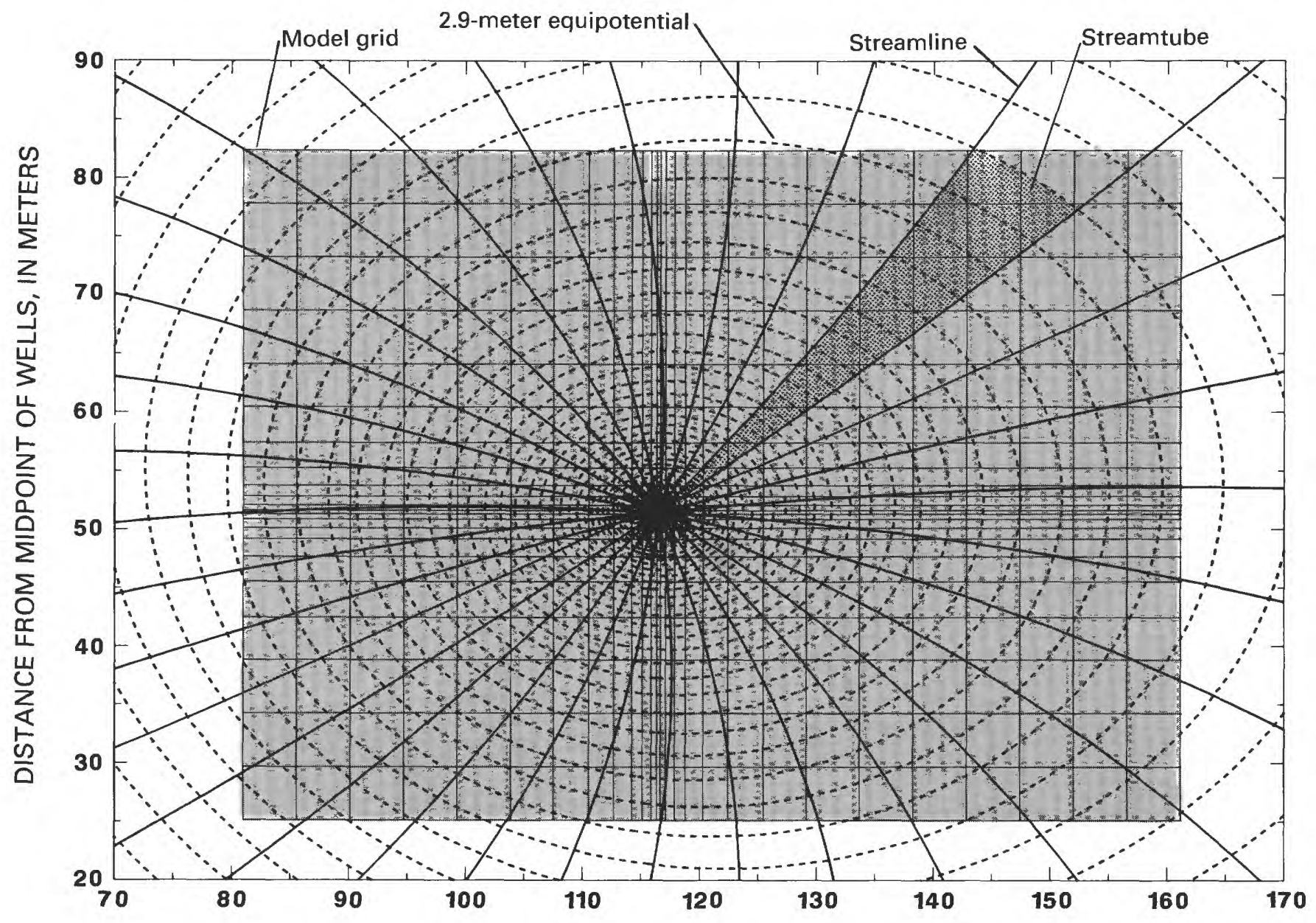

DISTANCE FROM MIDPOINT OF WELLS, IN METERS

FIGURE 42.-Model grid and flow net for the upper part of the Franconia Formation near production well A.

TABLE 11.-Layer number, thickness, and corresponding hydrogeologic unit of vertical grid spacing for the three-dimensional model

\begin{tabular}{|c|c|c|}
\hline Layer & $\begin{array}{l}\text { Thickness } \\
\text { (meters) }\end{array}$ & Hydrogeologic unit \\
\hline 1 & 7.6 & St. Lawrence Formation (confining unit) \\
\hline 2 & 13.7 & $\begin{array}{l}\text { Upper part of the Franconia Formation } \\
\text { (aquifer) }\end{array}$ \\
\hline 3 & 24.4 & $\begin{array}{l}\text { Lower part of the Franconia Formation } \\
\text { (confining unit) }\end{array}$ \\
\hline 4 & 15.2 & Ironton Sandstone (aquifer) \\
\hline 5 & 6.1 & Galesville Sandstone (aquifer) \\
\hline 6 & 30.5 & Eau Claire Formation (confining unit) \\
\hline
\end{tabular}

The total flow crossing an equipotential is equal to the injection rate and is thus known; also, equal-portion flow occurs in each streamtube. Therefore, assuming quasisteady flow, the distribution of fluxes along an equipotential is known for any injection history.
One form of boundary-flux specification allowed by the SWIP code (Intercomp, 1976, p. 3.13) is

$$
e w_{i j}(t)=\alpha_{i j} V\left(P_{I}-P_{i j}^{n+1}\right)
$$

where

$e w_{i j}=$ the fluid influx rate at boundary cell $i, j\left[l^{3} / t\right]$ $\left(\mathrm{m}^{3} / \mathrm{s}\right)$,

$\alpha_{i j}=\mathrm{a}$ constant factor that gives the fraction of the entire grid boundary that cell $i, j$ represents [dimensionless],

$V=$ an aquifer flux coefficient $\left[l^{3} / \mathrm{t}-\left(m / l-t^{2}\right)\right]\left(\mathrm{m}^{3} / \mathrm{s}-\right.$ $\mathrm{Pa})$,

$P_{I}=$ a fixed pressure at some distance outside the aquifer model boundary $\left[\mathrm{m} / \mathrm{l}-\mathrm{t}^{2}\right](\mathrm{Pa})$,

$P_{i j}^{n+1}=$ the pressure in boundary cell $i, j$ at time of the $(n+1)$ th time step $\left[m / l-t^{2}\right](\mathrm{Pa})$.

For an infinite aquifer, $P_{I}$ is maintained at the initial system pressure before pumping. For simulation of the 


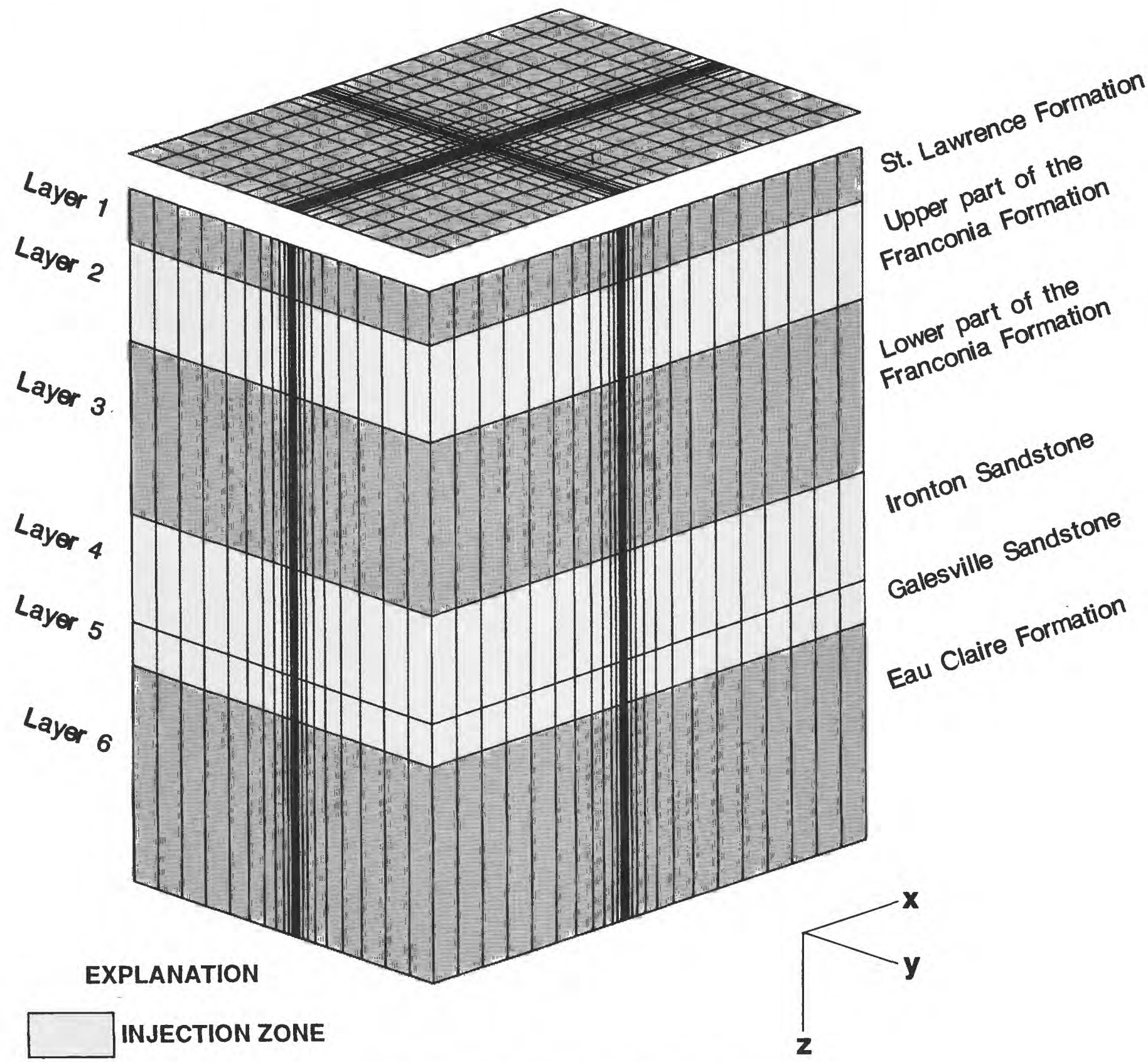

FIGURE 43. - Finite-difference grid in three dimensions.

doublet-well system, the initial pressure $\left(P_{i j}\right)$ is maintained at all times along a locus somewhere between the wells. In a homogeneous isotropic aquifer this locus would be the perpendicular bisector of the well axis. However, in the anisotropic Franconia-IrontonGalesville aquifer, the locus is not along a line perpendicular to the well axis, but rather along a line at an oblique angle to the well axis (see figs. 39 and 40). Thus the coefficient $(V)$ is calculated with equation 36 for an equipotential by letting $P_{I}$ equal initial pressure, $\alpha_{i j}=1$ (representing the entire boundary), $e w_{i j}$ equal the steady injection rate, and $P_{i j}^{n+1}$ equal the steady-state pressure at the equipotential. Values of $V$ were calculated for the 10-m equipotential (fig. 41) for the Ironton and Galesville Sandstones and the 2.9-m equipotential (fig. 42) for the upper part of the Franconia Formation, as 12.6 and 3.8 $\mathrm{m}^{3} / \mathrm{d}-\mathrm{kPa}$, respectively. Noting that the 32 streamtubes illustrated in figures 41 and 42 all have equal rates of flow, values for $\alpha_{i j}$ were determined around the model boundary for each model layer based on the number of 


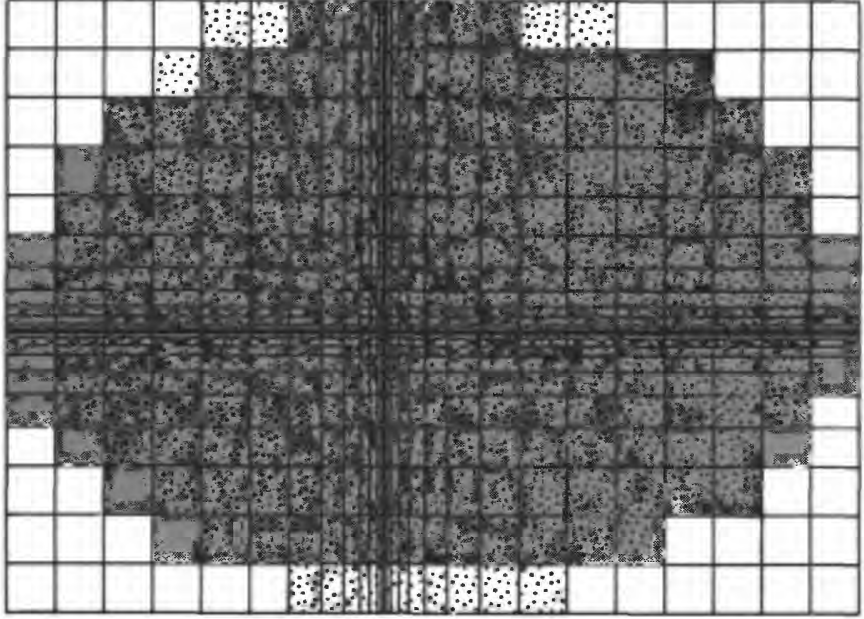

\section{EXPLANATION}

\section{Model area:}

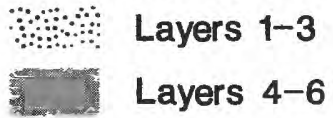

FigURE 44.-Location of lateral flux boundaries in the model. streamtubes that each boundary cell intersects. The respective equipotential boundaries were simulated by the model with the flux boundaries illustrated in figure 44 .

\section{MODEL CALIBRATION FOR ISOTHERMAL CONDITIONS}

Data from an 8-day, ambient-temperature injection test at $18.9 \mathrm{~L} / \mathrm{s}$ were used for model calibration. Table 12 summarizes the hydraulic data by model layer used for isothermal calibration. Pressure changes in production well A and observation well AM2 are compared to model-computed values in figure 45 .

The data shown in figure 45 indicate that model results approximate the field-test data, and that the boundary fluxes are adequately described by equation 36 . Model results also indicate that the method of apportioning flow at the model boundary by flow-net analysis reasonably represents the doublet-well flow field in the anisotropic aquifer. Based on the flow-net analysis of various conditions of injection and withdrawal, the lateral extent of the finite-difference grid around the injection well can be varied. The system can be modeled in an economical and yet physically meaningful manner.

Application of the model to nonisothermal simulations, with boundary fluxes determined from isothermal flownet analysis, is predicated on the assumption that the head near the boundary does not change significantly

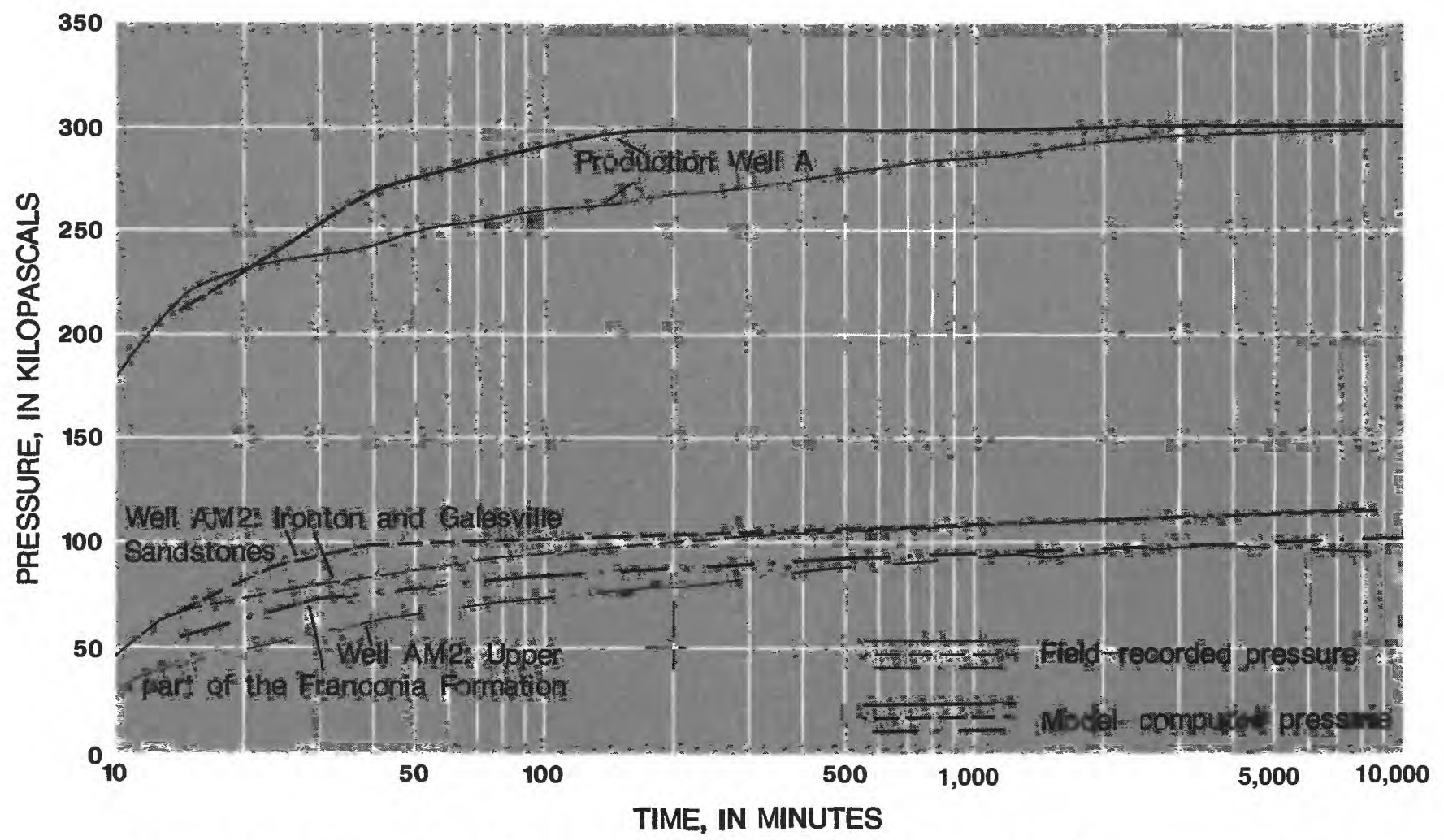

FiguRE 45.-Model-computed and field-recorded pressure changes in production well A and observation well AM2. 


\begin{tabular}{lcccc}
\multicolumn{5}{c}{ TABLE 12. - Hydraulic data by model layer } \\
\hline $\begin{array}{c}\text { Model } \\
\text { layer }\end{array}$ & \multicolumn{3}{c}{$\begin{array}{c}\text { Hydraulic conductivity } \\
\text { in meters per day }\end{array}$} & $\begin{array}{c}\text { Porosity } \\
\text { (percent) }\end{array}$ \\
\cline { 2 - 5 } & $K_{x}$ & $K_{y}$ & $K_{z}$ & 26.8 \\
1 & 0.003 & 0.003 & 0.00003 & 28.2 \\
3 & 2.89 & 1.71 & .222 & 27.3 \\
4 & .03 & .03 & .0003 & 25.2 \\
5 & 5.78 & 2.001 & .380 & 25.6 \\
6 & 1.45 & .628 & .095 & 31.6 \\
\hline
\end{tabular}

because of temperature changes during hot-water injection. To examine this assumption, 8 days of injection of $150^{\circ} \mathrm{C}$ water at $18.9 \mathrm{~L} / \mathrm{s}$ was simulated using the isothermal calibrated model. Equipotentials in the Ironton and Galesville Sandstones were constructed from computed pressure data and compared with the equipotential from the flow-net analysis (fig. 46). The temperature along the model boundary was approximately $38^{\circ} \mathrm{C}$. Figure 46 shows that the shape and position of the 10-m equipotential for simulated hot-water injection is similar in shape and position to that derived from the flow-net analysis of the injection of ambient-temperature water. It may be that injection and withdrawal rates will not remain constant at the planned $18.9 \mathrm{~L} / \mathrm{s}$ rate during hot-water testing because of limitations of the above-ground piping and the need for system maintenance. However, the rates are not expected to fluctuate more than about 3 percent, or $0.6 \mathrm{~L} / \mathrm{s}$. It is possible to account for transient changes in the injection and withdrawal rates; however, with the SWIP code, it is not possible to redefine the boundary-flux condition to accommodate these rate changes to determine the sensitivity of model computed heads to changes in injection and withdrawal rates. Two different 24-day test cycles at injection and withdrawal rates of 15.8 and $22.1 \mathrm{~L} / \mathrm{s}$ were simulated and compared with computed heads for an injection and withdrawal rate of $18.9 \mathrm{~L} / \mathrm{s}$. All three simulations had flux-boundary conditions determined for an injection and withdrawal rate of $18.9 \mathrm{~L} / \mathrm{s}$.

Table 13 summarizes the model-computed headchange data in wells AM2 and AM3 for the injection and withdrawal rates of 15.8 and $22.1 \mathrm{~L} / \mathrm{s}$. The values represent the computed change in head for the respective rate as compared to the computed head for the $18.9 \mathrm{~L} / \mathrm{s}$ rate. Negative values are lower computed heads, and positive values are higher computed heads. The grid locations chosen for comparison correspond to the approximate locations of monitoring wells AM2 and AM3.

The model-computed head changes in table 13 indicate that large head differences may be computed by the model if the model boundary-flux conditions are not determined by a representative rate. The results also suggest that head differences may directly correlate to

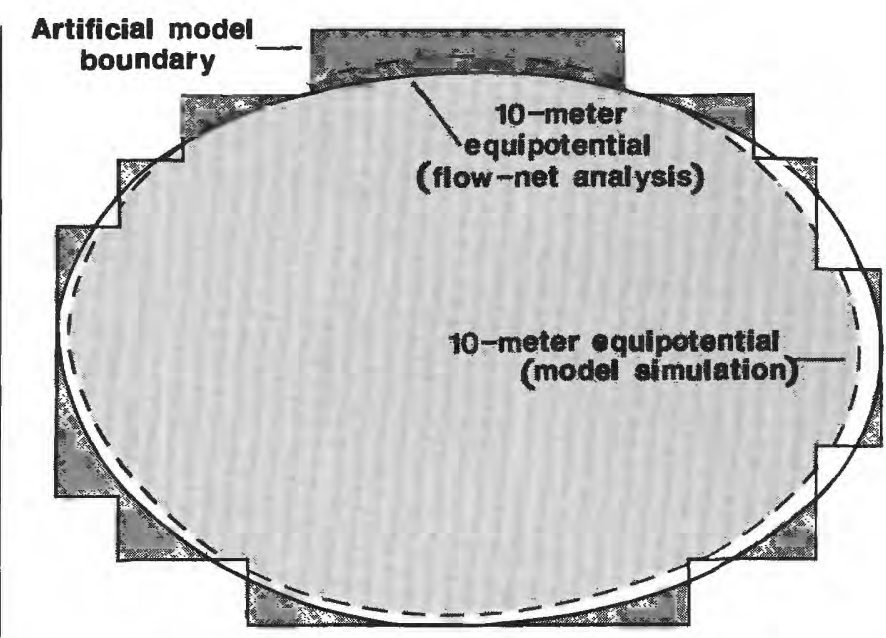

FIGURE 46. - Shape of lines of equipotential after 8 days of injection of ambient-temperature and $150^{\circ} \mathrm{C}$ water at 18.9 liters per second.

TABLE 13.-Difference in computed heads for injection and withdrawal rates of 15.8 and 22.1 liters per second as compared to 18.9 liters per second for a flux-boundary condition determined for 18.9 liters per second

\begin{tabular}{lccccc}
\hline & \multicolumn{4}{c}{ Computed head change, in meters } \\
\cline { 2 - 3 } $\begin{array}{l}\text { Well } \\
\text { number }\end{array}$ & \multicolumn{2}{c}{ Rate of 15.8 liters per second } & & \multicolumn{2}{c}{ Rate of 22.1 liters per second } \\
\cline { 2 - 3 } \cline { 5 - 6 } & Injection & Withdrawal & & Injection & Withdrawal \\
\hline AM2 & -2.88 & -1.85 & & +2.87 & +1.86 \\
AM3 & -2.38 & -1.92 & & +2.40 & +1.91 \\
\hline
\end{tabular}

changes in flow rate regardless of flow direction. The head-change results indicate that the model boundary fluxes are valid for at least relatively short injection periods. It will be necessary, however, to increase the model region if the shape of the equipotentials near the model boundary are affected by temperature during longer simulated periods of injection.

\section{SUMMARY}

In May 1980, the University of Minnesota began an ATES (Aquifer Thermal-Energy Storage) study on the St. Paul campus. The ATES system uses a doublet well with an injection and withdrawal-well spacing of approximately $250 \mathrm{~m}$. Hot water $\left(150^{\circ} \mathrm{C}\right)$ was injected into the deep (180 to $240 \mathrm{~m}$ ) Franconia-Ironton-Galesville aquifer, a consolidated sandstone. The aquifer is confined above by the St. Lawrence Formation, a dolomitic sandstone, and below by the Eau Claire Formation, a shale. Short-term testing consisted of 8 days of injection at $18.9 \mathrm{~L} / \mathrm{s}$ of $150^{\circ} \mathrm{C}$ water, 8 days of storage, and 8 days of withdrawal of heated water at $18.9 \mathrm{~L} / \mathrm{s}$.

Monitoring-well locations were determined by using an analytical one-dimensional radial-flow model. 
Temperature and pressure within the aquifer and the overlying and underlying confining units were measured at four monitoring wells, two at distances of $7 \mathrm{~m}$ and two at distances of $14 \mathrm{~m}$. During testing, pressure at 22 points and temperatures at 56 points were recorded automatically by a central data logger and stored on magnetic tape.

Methods to determine the hydraulic characteristics of the aquifer included packer testing, borehole geophysical logging, core sampling, step-drawdown tests, constantrate aquifer tests, laboratory tests on core samples for permeability and effective porosity, and ambienttemperature water-injection testing. Packer-test results indicate that the aquifer is divided into four zones based on values of relative horizontal hydraulic conductivity. The aquifer is anisotropic. Major and minor transmissivities are 101.5 and $44.6 \mathrm{~m}^{2} / \mathrm{d}$, respectively, for the Ironton and Galesville Sandstones and 40.0 and $24.0 \mathrm{~m}^{2} / \mathrm{d}$, respectively, for the upper part of the Franconia Formation. The average effective porosity for the Franconia-Ironton-Galesville aquifer ranges from 25 to 31 percent and the average storage coefficient is $4.5 \times 10^{-5}$.

Results of ambient-temperature water-injection tests indicate that the aquifer approaches steady-state conditions within 1 day for an injection rate of approximately $19 \mathrm{~L} / \mathrm{s}$.

A preliminary radial-flow model for ground-water flow and thermal-energy transport was constructed using a code developed for waste-injection problems. Vertically, the model consists of six layers ranging from approximately $6 \mathrm{~m}$ to $30 \mathrm{~m}$ thick; these layers simulate the aquifer and the confining units.

Sensitivity analysis was performed on the preliminary radial-flow and thermal-energy-transport model for hydraulic conductivity, porosity, ratio of horizontal hydraulic conductivity $\left(K_{H}\right)$ to vertical hydraulic conductivity $\left(K_{V}\right)$, rock-thermal conductivity, rock-heat capacity, and thermal dispersivity. Each simulation consisted of 8 days of injection of $150^{\circ} \mathrm{C}$ water at $18.9 \mathrm{~L} / \mathrm{s}, 8$ days of storage, and 8 days of withdrawal at $18.9 \mathrm{~L} / \mathrm{s}$ for one complete 24-day cycle. Individual model properties were varied from the assumed base values, and plots of model-computed temperature versus time were constructed at a radial distance of approximately $6.5 \mathrm{~m}$ from the well bore. The resultant curves then were compared with each other and with those for other model properties to determine model sensitivity in terms of calculated temperature and aquifer thermal efficiency. Model results indicate that hydraulic and thermal properties may be ranked in terms of increasing model sensitivity as follows: ratio of $K_{H}$ to $K_{V}$, rock-thermal conductivity, hydraulic conductivity, porosity, rock-heat capacity, and thermal dispersivity.
The preliminary radial-flow and thermal-energytransport model was used to study the potential effects of thermal convection, termed buoyancy flow, that are due to density differences between the cooler ambienttemperature ground water and the heated injection water. Eight-day injection of $150^{\circ} \mathrm{C}$ water at $18.9 \mathrm{~L} / \mathrm{s}$, storage, and withdrawal at $18.9 \mathrm{~L} / \mathrm{s}$ were simulated. Values of hydraulic conductivity and the ratio of horizontal to vertical hydraulic conductivity were individually varied by an order of magnitude. Vertical profiles of temperature were constructed at the end of injection, storage and withdrawal at a radial distance of $6.5 \mathrm{~m}$. Tilting of the thermal front caused by buoyancy flow was not apparent in the temperature profiles at the end of injection, storage, or withdrawal for the assumed base values of hydraulic and thermal properties. The simulation of horizontal hydraulic conductivity at 10 times the base value and $K_{V}$ equal to $K_{H}$ resulted in significant tilting of the thermal front at the end of storage and withdrawal, indicating the importance of accurate data collection and analyses for these two hydraulic properties.

The preliminary radial-flow and thermal-energytransport model also was used to examine the effects on aquifer thermal efficiency of hypothetical test cycles that consisted of various periods and rates of injection and withdrawal of hot water. Simulations consisted of five injection and withdrawal cycles of 1-year duration representing a total of 5 years of system operation. In all simulations, injection was $18.9 \mathrm{~L} / \mathrm{s}$ of $150^{\circ} \mathrm{C}$ water. Aquifer thermal efficiency was calculated as total energy withdrawn divided by total energy injected. The leastefficient cycle simulated consisted of 8 months of injection at $18.9 \mathrm{~L} / \mathrm{s}$ and 4 months of withdrawal at $18.9 \mathrm{~L} / \mathrm{s}$. The aquifer efficiency calculated at the end of the fifth cycle was 39 percent and the final well-bore temperature was $105^{\circ} \mathrm{C}$. The most efficient simulation consists of 6 -months injection at $18.9 \mathrm{~L} / \mathrm{s}$ and 6 -months withdrawal at $37.8 \mathrm{~L} / \mathrm{s}$. The calculated efficiency after five cycles was 84 percent, and the final well-bore temperature was $45^{\circ} \mathrm{C}$.

A three-dimensional, nonisothermal, ground-waterflow and thermal-energy-transport model was constructed to account for the anisotropic characteristics of the Franconia-Ironton-Galesville aquifer. The model consisted of 27 columns, 22 rows, and 6 layers and covered about $4,800 \mathrm{~m}^{2}$. The six model layers represented the four hydraulic zones in the aquifer and the upper and lower confining units.

Equipotentials and streamlines from a flow-net analysis of a doublet-well system in an infinite, isotropic aquifer were modified to account for field conditions. The 
modifications of the radial flow model included rotation of coordinate axes and transposition from an isotropic to an anisotropic condition.

Examination of a flow net for the Ironton and Galesville Sandstones indicates that approximate symmetry is not available to reduce the size of the finite-difference model grid and that a model of the entire doublet-well system would be costly. An alternative method was utilized by designing a model grid for the area near the injection well where significant heat transport occurred, and to specify water fluxes at the model boundary to simulate the effects of the remaining flow field.

A method for calculating water flux in the center of the flow field combined with known steady-state heads was used to calculate model-boundary fluxes. The model boundary then was subdivided into equal-flux segments, and water flux at each boundary cell was computed based on the number of stream tubes that intersect each cell.

The validity of model-boundary fluxes determined from flow-net analyses was tested by simulation of an ambient-temperature injection test. The model satisfactorily simulated field-reported pressure changes measured in two piezometers for 8 days of ambienttemperature injection at $18.9 \mathrm{~L} / \mathrm{s}$. Applicability of the model boundary fluxes to nonisothermal flow was examined by simulating 8 days of injection of $150^{\circ} \mathrm{C}$ water at $18.9 \mathrm{~L} / \mathrm{s}$ and comparing the resultant $10-\mathrm{m}$ equipotential with that from flow-net analysis. The shape and location of the equipotentials were not significantly changed for the period of simulation and, thus, the fluxes across the boundary were considered to be adequate for representation of the large-scale flow field. The finite-difference grid and the boundary fluxes could be modified to simulate other injection and withdrawal conditions for the doublet-well system as needed.

\section{REFERENCES CITED}

Bear, J., 1972, Dynamics of fluids in porous media: American Elsevier, New York, 764 p.

Birch, F., and Clark, H., 1940, The thermal conductivity of rocks and its dependence upon temperature and composition: American Journal of Science, v. 238, no. 8, p. 529-558.

Clark, S.P., 1966, Handbook of physical constants: Geological Society of America Memoir 97, p. 291-300.

Cooper, H.H., Jr., 1963, Type curves for nonsteady radial flow in an infinite leaky artesian aquifer in Bentall, Ray, ed., Shortcuts and special problems in aquifer tests: U.S. Geological Survey WaterSupply Paper 1545-C, p. C48-C55.

Czarnecki, J.B., 1983, Fortran computer programs to plot and process aquifer pressure and temperature data: U.S. Geological Survey Water-Resources Investigations Report 83-4051, $50 \mathrm{p}$.

Czarnecki, J.B., and Craig, R.W., 1985, Computer notes-a program to calculate aquifer transmissivity from specific-capacity data for programmable calculators: Ground-water, v. 23 , no. 5, p. 667-672.
Foxworthy, B.L., 1970, Hydrologic conditions and artificial recharge through a well in Salem Heights area of Salem, Oregon: U.S. Geological Survey Water-Supply Paper 1594-F, 56 p.

Foxworthy, B.L., and Bryant, C.T., 1967, Artificial recharge through a well tapping basalt aquifers at The Dalles, Oregon: U.S. Geological Survey Water-Supply Paper 1594-E, 55 p.

Freeze, R.A., and Cherry, J.A., 1979, Ground water: Englewood Cliffs, N.J., Prentice-Hall, $604 \mathrm{p}$.

Gringarten, A.C., and Sauty, J.P., 1975, A theoretical study of heat extraction from aquifers with uniform regional flow: Journal of Geophysical Research, v. 80, no. 35, p. 4956-4962.

Guyton, W.F., 1946, Artificial recharge of glacial sand and gravel with filtered river water at Louisville, Kentucky: Economic Geology, v. 41(6), p. 644-658.

Harrill, J.R., 1970, Determining the transmissivity from water-level recovery of a step-drawdown test: U.S. Geological Survey Professional Paper 700-C, p. C212-213.

Hausz, W., 1974, Heat storage in wells: Institute of Gas Technology Symposium, April 17, 1974, Chicago, Illinois, 8 p.

Helgeson, H.C., Delaney, J.M., Nesbitt, H.W., and Bird, D.K., 1978, Summary and critique of the thermodynamic properties of rock forming minerals: American Journal of Science, v. 278-A, 229 p.

Hellstrom, G., Tsang, C.G., and Claesson, Johan, 1979, Heat storage in aquifers. Buoyancy flow and thermal stratification in aquifer hot-water storage: Lund University, Sweden, p. 70.

Intercomp Resources Development and Engineering, Inc., 1976, A model for calculating effects of liquid waste disposal in deep saline aquifers: U.S. Geological Survey Water-Resources Investigations Report 76-61, 265 p.

Kanivetsky, R., 1978, Hydrogeologic map of Minnesota, bedrock hydrogeology: Minnesota Geological Survey State Map Series, Map S-2, 1 pl.

Kazmann, R.G., 1971, Exotic uses of aquifers: Proceedings of American Society of Civil Engineers, v. 97 (IR3), p. 515-522.

Labadie, J.W., and Helweg, O.J., 1975, Step-drawdown test analysis by computer: Ground-water, v. 13 , no. 5, p. 438 451 .

Lawrence Berkeley Laboratory, 1978, Thermal Energy Storage in aquifers: Lawrence Berkeley Laboratory Publication LBL, Report 8431.

Leggette, R.M., and Brashears, M.L., Jr., 1938, Ground-water for air conditioning on Long Island, New York: Transactions of the American Geophysical Union, p. 412-418.

Lohman, S.W., 1972, Ground-water hydraulics: U.S. Geological Survey Professional Paper 708, $70 \mathrm{p}$.

Martin, W.L., and Dew, J.N., 1965, How to calculate air requirements for forward combustion: Petroleum Engineer, February 1965.

Mercer, J.W., Faust, C.R., Miller, W.J., and Pearson, F.J., Jr., 1982, Review of simulation techniques for aquifer thermal energy storage (ATES), Battelle Pacific Northwest Labs., PNL-3769, p. 183.

Meyer, C.F., and Todd, D.K., 1973, Conserving energy with heat storage wells: Environmental Science and Technology, v. 7, no. 6, p. 512-516.

Meyer, C.F., Todd, D.K., and Hare, R.C., 1976, Role of heat storage wells in future U.S. energy systems: General Electric TEMPO, GE76TMP-27A.

Miller, R.T., 1984, Anisotropy of the Ironton-Galesville Sandstones near a thermal-energy-storage well, St. Paul, Minnesota: Groundwater, v. 22 , no. 5 , p. 532-537.

Miller, R.T., and Voss, C.I., 1986, Finite-difference grid for a doublet well in an anisotropic aquifer: Ground-water, v. 24 , no. 4 , p. $490-496$.

Molz, F.J., Warman, J.C., and Jones, T.E., 1978, Aquifer storage of heated water: Part I, A field experiment: Ground-water, v. 16, no. 4, p. 234-241. 
Norvitch, R.F., Ross, T.G., and Brietkrietz, Alex, 1973, Water resources outlook for the Minneapolis-St. Paul Metropolitan Area, Minnesota: Metropolitan Council of the Twin Cities, $219 \mathrm{p}$.

Norvitch, R.F., and Walton, M.S., eds., 1979, Geology and hydrologic aspects of tunneling in the Twin Cities area, Minnesota: U.S. Geological Survey Miscellaneous Map Series, Map 1157, 7 sheets.

Papadopulos, I.S., 1967, Nonsteady flow to a well in an infinite anisotropic aquifer: International Association of Scientific Hydrology, Proceedings of Dubrovinik Symposium, v. 1, pub. no. 73, p. 21-31.

Reeder, H.O., Wood, W.W., Ehrlich, G.G., and Sun, R.J., 1976, Artificial recharge through a well in fissured carbonate rock, West St. Paul, Minnesota: U.S. Geological Survey Water-Supply Paper 2004, $80 \mathrm{p}$.

Robie, R.A., Hemmingway, B.S., and Fisher, J.R., 1978, Thermodynamic properties of minerals and related substances at $298.15 \mathrm{~K}$ and $1 \mathrm{Bar}\left(10^{5}\right.$ pascals $)$ pressure and at higher temperatures: U.S. Geological Survey Bulletin 1452, $456 \mathrm{p}$.

Rorabaugh, M.I., 1953, Graphical and theoretical analysis of stepdrawdown test of artesian wells: Transactions American Society of Civil Engineers, v. 79, Separate 362, 23 p.

Sauty, J.P., Gringarten, A.C., and Landel, P.A., 1978, The effect of thermal dispersion on injection of hot water in aquifers in Proceedings of Second Invitational Well Testing Symposium, Lawrence Berkeley Laboratory, Berkeley, California: p. 122-131.

Sniegocki, R.T., 1963, Problems in artificial recharge through wells in the Grand Prairie Region, Arkansas: U.S. Geological Survey Water-Supply Paper 1615-F, 25 p.
Somerton, W.H., Mehta, M.M., and Dean, G.W., 1965, Thermal alteration of sandstones: Journal of Petroleum Technology, v. 17, no. 5, p. 589-593.

Theis, C.V., 1935, The relation between the lowering of the piezometric surface and the rate and duration of discharge of a well using ground-water storage: American Geophysical Union Transaction, v. 16, p. $519-524$.

Theis, C.V., Brown, R.H., and Meyer, R.R., 1963, Estimating the transmissivity of aquifers from the specific capacity of wells, in Bentall, R., compiler, Methods for determining permeability, transmissivity and drawdown: U.S. Geological Survey WaterSupply Paper 1536-I, p. 331-341.

Tsang, C.F., 1979, A review of current aquifer thermal energy storage projects: Lawrence Berkeley Laboratory, LBL-9834, 21 p.

Walton, M., 1981, The University of Minnesota aquifer thermal-energy storage system in Proceedings of the Mechanical, Magnetic, and Underground Energy Storage, 1981 Annual Contractors Review: U.S. Department of Energy, August 24-26, 1981, Washington D.C.

Walton, M., Eisenreich, S.J., Holm, N.L., Holm, T.R., Kanivetsky, R., Jirsa, M.A., Lee, H.C., Lauer, J.L., Miller, R.T., Norton, J.L., and Runke, H., 1991, The University of Minnesota aquifer thermal energy storage (ATES) field test facility-system description, aquifer characterization, and results of short-term test cycles: Pacific Northwest Laboratory Report PNL-7220, UC-202, 295 p. Werner, D., and Kley, W., 1977, Problems of heat storage in aquifers: Journal of Hydrology, v. 34, p. 35-43. 



\section{SELECTED SERIES OF U.S. GEOLOGICAL SURVEY PUBLICATIONS}

\section{Periodicals}

Earthquakes \& Volcanoes (issued bimonthly).

Preliminary Determination of Epicenters (issued monthly).

\section{Technical Books and Reports}

Professional Papers are mainly comprehensive scientific reports of wide and lasting interest and importance to professional scientists and engineers. Included are reports on the results of resource studies and of topographic, hydrologic, and geologic investigations. They also include collections of related papers addressing different aspects of a single scientific topic.

Bulletins contain significant data and interpretations that are of lasting scientific interest but are generally more limited in scope or geographic coverage than Professional Papers. They include the results of resource studies and of geologic and topographic investigations, as well as collections of short papers related to a specific topic.

Water-Supply Papers are comprehensive reports that present significant interpretive results of hydrologic investigations of wide interest to professional geologists, hydrologists, and engineers. The series covers investigations in all phases of hydrology, including hydrogeology, availability of water, quality of water, and use of water.

Circulars present administrative information or important scientific information of wide popular interest in a format designed for distribution at no cost to the public. Information is usually of short-term interest.

Water-Resources Investigations Reports are papers of an interpretive nature made available to the public outside the formal USGS publications series. Copies are reproduced on request unlike formal USGS publications, and they are also available for public inspection at depositories indicated in USGS catalogs.

Open-File Reports include unpublished manuscript reports, maps, and other material that are made available for public consultation at depositories. They are a nonpermanent form of publication that may be cited in other publications as sources of information.

\section{Maps}

Geologic Quadrangle Maps are multicolor geologic maps on topographic bases in 7.5- or 15-minute quadrangle formats (scales mainly $1: 24,000$ or $1: 62,500$ ) showing bedrock, surficial, or engineering geology. Maps generally include brief texts; some maps include structure and columnar sections only.

Geophysical Investigations Maps are on topographic or planimetric bases at various scales; they show results of surveys using geophysical techniques, such as gravity, magnetic, seismic, or radioactivity, which reflect subsurface structures that are of economic or geologic significance. Many maps include correlations with the geology.

Miscellaneous Investigations Series Maps are on planimetric or topographic bases of regular and irregular areas at various scales; they present a wide variety of format and subject matter. The series also includes 7.5-minute quadrangle photogeologic maps on planimetric bases that show geology as interpreted from aerial photographs. Series also includes maps of Mars and the Moon.
Coal Investigations Maps are geologic maps on topographic or planimetric bases at various scales showing bedrock or surficial geology, stratigraphy, and structural relations in certain coal-resource areas.

Oil and Gas Investigations Charts show stratigraphic information for certain oil and gas fields and other areas having petroleum potential.

Miscellaneous Field Studies Maps are multicolor or black-andwhite maps on topographic or planimetric bases for quadrangle or irregular areas at various scales. Pre-1971 maps show bedrock geology in relation to specific mining or mineral-deposit problems; post-1971 maps are primarily black-and-white maps on various subjects such as environmental studies or wilderness mineral investigations.

Hydrologic Investigations Atlases are multicolored or blackand-white maps on topographic or planimetric bases presenting a wide range of geohydrologic data of both regular and irregular areas; principal scale is $1: 24,000$, and regional studies are at $1: 250,000$ scale or smaller.

\section{Catalogs}

Permanent catalogs, as well as some others, giving comprehensive listings of U.S. Geological Survey publications are available under the conditions indicated below from the U.S. Geological Survey, Map Distribution, Box 25286, Bldg. 810, Federal Center, Denver, CO 80225. (See latest Price and Availability List.)

"Publications of the Geological Survey, 1879-1961" may be purchased by mail and over the counter in paperback book form and as a set of microfiche.

"Publications of the Geological Survey, 1962-1970" may be purchased by mail and over the counter in paperback book form and as a set of microfiche.

"Publications of the U.S. Geological Survey, 1971-1981" may be purchased by mail and over the counter in paperback book form (two volumes, publications listing and index) and as a set of microfiche.

Supplements for 1982, 1983, 1984, 1985, 1986, and for subsequent years since the last permanent catalog may be purchased by mail and over the counter in paperback book form.

State catalogs, "List of U.S. Geological Survey Geologic and Water-Supply Reports and Maps For (State)," may be purchased by mail and over the counter in paperback booklet form only.

"Price and Availability List of U.S. Geological Survey Publications," issued annually, is available free of charge in paperback booklet form only.

Selected copies of a monthly catalog "New Publications of the U.S. Geological Survey" are available free of charge by mail or may be obtained over the counter in paperback booklet form only. Those wishing a free subscription to the monthly catalog "New Publications of the U.S. Geological Survey" should write to the U.S. Geological Survey, 582 National Center, Reston, VA 22092.

Note.-Prices of Government publications listed in older catalogs, announcements, and publications may be incorrect. Therefore, the prices charged may differ from the prices in catalogs, announcements, and publications. 
